\title{
Structures and Forms of Existence
}

\subsection{Introduction}

This chapter deals with a sphere that is both wide-ranging and extremely hard to define, a sphere usually referred to as culture. It is not possible to ascertain in full the characteristics of the Pechenegs' culture. The fragmentary nature of written and archaeological sources allows us only to outline the most characteristic elements of the culture that grew out of the Pechenegs' nomadic lifestyle and shaped the quality of this steppe people's relations with their settled neighbours.

The Pechenegs remained nomads throughout their existence as an independent people. Their contacts with sometimes highly developed agricultural communities undoubtedly influenced them, but did not radically change their way of life. Neither the starkly different natural conditions of their new home nor close relations with other culturally dissimilar communities - two factors that often put nomadic groups on a path to sweeping cultural change - had a significant impact on Pechenegs until the mid-11th century. We can point to two other nomadic communities, the Volga-Kama and Danube Bulgars, as examples of groups that underwent a process of acculturation and sedentarization due to such factors.

As a result of events which took place in the mid-7th century, the Danube Bulgars were forced to leave the Black Sea steppe and relocate to the Lower Danube. They ultimately settled in today's north-eastern Bulgaria. Recent research shows that the Volga-Kama Bulgars did not reach the mouth of the Kama River, where it flows into the Volga, until the mid-8th century. ${ }^{1}$ In their new homelands, both nomadic groups met a settled population whose culture differed from theirs. In the case of the Volga-Kama Bulgars, these were Finno-Ugric peoples living in forests where they hunted and Alano-Sarmatian agricultural communities. ${ }^{2}$ The members of the Danube Bulgars led by Asparukh, in turn, came into contact with Slavic agricultural peoples who were dominant in terms of numbers. ${ }^{3}$ In both cases, the necessary conditions

1 Cf. Chapter 2 of the present book.

2 Tryjarski 1975 183; Fakhrutdinov 1984, 14-26; Zimonyi 199o, 64-83.

3 Tryjarski 1975, 271-273; Kurnatowska 1977, 89-9o; Beshevliev 1981, 179-181; 1984, 6o-61; Wasilewski 1988, 35 .

(C) ALEKSANDER PAROŃ AND INSTITUTE OF ARCHAEOLOGY AND ETHNOLOGY POLISH ACADEMY OF SCIENCES, 2021 | DOI:10.1163/9789004441095_006

This is an open access chapter distributed under the terms of the CC BY-NC-ND 4te licensender Paroń - 9789004441095 
existed for dynamic cultural exchange between the politically dominant but less numerous nomadic groups and the rest of the local population. For both Bulgar groups, a change in their geographical environment played a vitally important role in intensifying the process of sedentarization. ${ }^{4}$ This was particularly true for the Volga-Kama Bulgars. When they settled in their new homeland, which was full of forests, swamps, and rivers, they were forced to reduce the role that pastoralism played in their economy. Its place was taken in part by activities that were completely alien to such nomadic communities (e.g., fishing, harvesting honey, etc.). ${ }^{5}$ However, this process of acculturation was arduous and progressed slowly. An important role in delaying acculturation, especially in the beginning, was played by the nomads' conscious attempts to maintain their cultural distinction, as well as their hostility towards the indigenous local peoples. The example of the Danube Bulgars shows that the process of overcoming this hostility could take centuries; we can observe a phenomena that allows us to assess the progress of this process only in the early${ }^{\text {th }}$ century. ${ }^{6}$ Distrust towards outsiders and their cultural milieu sometimes took the form of a cultural conservatism that manifested itself in an attachment to the 'old ways of life', despite the fact that these practices sometimes had no practical value in the new living environment. Yet this conservatism was not absolute and did not rule out the possibility of adopting foreign cultural models. ${ }^{7}$ In the case of the Danube Bulgars, a sentiment for their old lifestyle, which seems to have been reflected in hybrid dwellings that combined the features of a yurt and a basin house, ${ }^{8}$ was accompanied by a willingness among their elites to incorporate cultural novelties. The second generation of Bulgar monarchs, for example, were already beginning to borrow methods for demonstrating power from the Byzantine empire. ${ }^{9}$ Borrowings of this kind were incorporated into their existing pagan system of values. Therefore, the disintegration of their former cultural universe, which could function only in

4 For general information on the sedentarization process in nomadic communities: Khazanov $1978,119-126 ; 1984,198-202 ; 1990,1-15$. Khazanov describes cultural change in nomads as a case of ecological change par excellence.

5 Tryjarski 1975, 192-194; Fakhrutdinov 1984, 27-36.

6 This mainly concerns the internal policies allegedly pursued by Khan Krum (8o2/8o3-814), who is believed to have sought to strengthen the role of Slavs in the governance of the Bulgarian State and to place them on an equal footing with the Bulgars. Tryjarski 1975, 276277; Beshevliev 1981, 264; 1984, 131; Halperin 2007, 88-89.

7 On this phenomenon in general: Paroń 2009, 43-54.

8 These are dated to the 8th and 9th centuries: Waklinow 1984, 93.

9 Atanasov 1999, 32-46; Havliková 1999, 407-420; Stepanov 1998, 247-254; 2001, 6-7, 13; Ziemann 2007, 307-308; Fiedler 2008, 169-188, 191-193, 193-196. 
a steppe milieu, was accompanied by a process of identity formation in which older traditions continued to play a considerable role.

Similar phenomena can be observed in the case of the Volga-Kama Bulgars. Although in the early 1oth century their lifestyle became largely sedentary, ${ }^{10}$ in the account of Ahmad ibn Fadlan, who visited their capital, we can find a wide range of information that indicates the ruler of Volga-Kama Bulgaria still had strong attachments to his people's former nomadic lifestyle." Therefore, although powerful factors promoting change were at work, the nomads' process of acculturation may have been a slow one and may not have resulted in a complete and immediate rejection of their previous identity.

For the Pechenegs, the chances of experiencing such radical cultural change were more limited. Unlike the Bulgar groups, the geographical conditions in their new surroundings did not differ significantly from their previous home in the Transvolga Region. The Black Sea steppe offered excellent conditions for extensive pastoralism, which comprised the foundation of a nomadic economy. ${ }^{12}$ Moreover, their contacts with other cultural communities were much less intensive. Nonetheless, during their time on the Black Sea steppe, the Pechenegs may have subjugated settled communities associated by archaeologists with the Balkan-Danube culture (so-called Dridu culture). ${ }^{13}$ The Pechenegs most likely extended their rule over this people, who inhabited western Wallachia and Moldavia. Particularly close contacts might have been established with them in the Lower Dniester region, north of the Danube Delta, from the Lower Prut in the west to the Cogîlnic in the east, and also in the lands between the Prut and Siret Rivers. ${ }^{14}$ It cannot be ruled out that the local population provided the nomads with farming products and handicrafts. Some items could have been given as tribute,$^{15}$ and others exchanged through barter. It is assumed, however, that factors such as differences in their economy, lifestyle, social organization, and spiritual culture fostered separation between them. ${ }^{16}$ The nomads and settled population therefore apparently lived side by side rather than together. While it cannot be ruled out that the two communities developed some sort of modus vivendi, the early nth century marked its

\footnotetext{
10 Tryjarski 1975, 191.

11 A most remarkable fact is that the ruler of the Volga-Kama Bulgars lived and received foreign emissaries in a yurt. ibn Fadlan: ibn Fadlan, 218/219, 228/229; Zeki Validi Togan 1939, 41-42, 64 .

12 Cf. Chapter 1 of the present book.

13 Diaconu 1975, 235; Spinei 1986, 103.

14 Spinei 1975, 274; 1986, 224, 226 (maps 1-2); Dobroliubskii 1986, 24 (fig. 1).

15 Diaconu 1975, 235; Spinei 1975, 273; 1986, 103.

16 Spinei 1975, 276; 1986, 104.
} 
end, as the agricultural population began to withdraw to upland and wooded areas that were more difficult for the nomads to reach. ${ }^{17}$

External cultural contacts were facilitated by the fact that the Pechenegs controlled an area that contained important trade routes and shared a border with Byzantium. However, the relations created by these circumstances remained sporadic in nature. In addition, the quality of the contacts between the Pechenegs and neighbouring countries often were not conducive to fruitful cultural exchange. Periods of peaceful cooperation recorded in written sources were interwoven with raids and bloody conflicts. Yet, there is reason to believe that there were instances of close contacts with neighbouring communities. One of the most interesting remarks on this issue comes from a work by Ibrahim ibn Yaqub. He lists a number of peoples, among them the Pechenegs, and claims that they spoke the language of the Slavs due to their close relations with them. ${ }^{18}$ This statement is very hard to believe. Perhaps Tadeusz Kowalski was correct when he claimed that this should be interpreted from the perspective of Ibrahim ibn Yaqub, i.e., from the perspective of a merchant. Finding a channel for communication that would make it possible to trade with foreign peoples was therefore of particular importance to him. Ibn Yaqub's remark thus need not be taken to mean that the Pechenegs' mother tongue was a Slavic dialect, but rather that in trade matters it was possible to communicate with them by means of a Slavic language..$^{19}$

It thus seems that as a culturally independent group, the Pechenegs remained nomads. Conditions conducive to cultural change, which ultimately led to their adopting a sedentary lifestyle, did not exist until the mid-11th century, when most of the ethnos had settled in the Byzantine Empire. However, the desire to maintain their old ways of life remained strong even then. ${ }^{20}$

A separate problem is the question of what elements of the nomads' culture determined the quality of their existence and relations with their settled neighbours. It is natural to begin addressing such a question with the issue of the Pechenegs' social and political organization. The survival of any human community exposed to turbulent historical events would most likely be impossible if its members did not establish at least basic socio-political structures. The nomads' strong means of organization, introduced mainly for the sake of carrying out military actions, sometimes gave them an advantage over less

17 Diaconu 1970, 37-48; 1975, 237; Spinei 1975, 274; 1986, 103. Cf. also Chapter 6 of the present book.

18 ibn Yaqub, 52; Mishin 1996, 19 o.

19 ibn Yaqub, 105 (n. 125).

20 Paroń 20oga, 443-474 and Chapter 7 of the present book. 
organized settled communities. ${ }^{21}$ It enabled them to impose political domination over farmers or at least force them to maintain the best possible relations with the belligerent nomads. Meanwhile, the nature of their organization, its efficiency and internal cohesion also determined the shape of their political relations with local powers. The last remark is particularly important in view of the fact that the Pechenegs bordered the Byzantine Empire.

The existence of any community, including a nomadic one, is conditioned by the nature of its economy. Therefore, the type of economy the Pechenegs had needs to be examined. As is the case with most nomads, their economy was dominated by pastoralism, which was accompanied by other, secondary forms of economic activity. Most nomadic communities, including the Pechenegs, were not economically self-sufficient. They were forced to satisfy their demand for products they could not produce themselves either through the exchange of goods or organized plundering. ${ }^{22}$ Nomads are often demonized for the level of intensity of these plundering raids. It needs to be remembered that these aggressive actions were often the only means available for overcoming the isolationist tendencies of a neighbouring state or simply an attempt to replenish food supplies, which were at times dramatically scarce. ${ }^{23}$ At the same time, it would be difficult to deny, in light of available source data, that the Pechenegs organized plundering raids with relatively regularity.

Another factor that made such a state of affairs possible was the Pechenegs' system of military organization. Bellicosity is a feature attributed to nomads in general. Kazimierz Moszyński claimed that apart from its economic impact, this bellicosity also nourished a specific way of life. ${ }^{24}$ Frequent attacks on settled communities, as well as particularly ruthless fighting on the steppe, the aim of which was the complete destruction of the opponent, contributed to the emergence of a specific sociopolitical organization and to the development of an extremely effective method of warfare. In this respect, the nomads sometimes surpassed much larger agricultural communities, whose members both watched the nomads' exploits with horror, and copied their methods of fighting in an effort to resist them more effectively. ${ }^{25}$ These general observations

\footnotetext{
21 Moszyński 1996, 30-31; Golden 2011a, 89-92.

22 Moszyński 1996, 27; Swoboda 1978, 413-14.

23 Cf. Paroń 2013b, 271-283.

24 Moszyński 1996, 26-27.

25 Moszyński 1996, 31. Many very spectacular examples come from China's interactions with the world of the steppe. In the early days of the Han Dynasty (until the 12OS BCE), the nomadic Xiongnu (Hsiung-nu) Empire enjoyed military dominance, which led the Chinese court to avoid armed confrontation with the nomads and to pursue a policy of peace, known as heqin (ho-ch'in), towards them. It was only after adopting elements of
} 
apply to the Pechenegs as well. Mounted military formations and the types of weapons typical of nomads became popular in Rus' as a result of encounters, or rather clashes, with the Pechenegs. ${ }^{26}$ Due to their military skills, small groups of the Pechenegs were enlisted into service by Byzantine emperors, as well as by Rus' and Hungarian rulers. ${ }^{27}$ Ultimately, and most importantly for our considerations, the bellicosity of the Pechenegs laid the foundations for their political significance.

The last, fourth part of this chapter is devoted to phenomena that shaped the feeling of community among the Pechenegs, contributed to the creation of a system of values universally recognized by this group, and constructed the image of these nomads in the eyes of their settled neighbours. Such factors strengthened the ethnic bond shared by members of this community and shaped a kind of nomadic ethos, thereby determining to a large extent the political actions undertaken by the Pechenegs. These factors also influenced their attitude towards neighbouring peoples, defined the value of the Pechenegs as a political partner for potential allies, and strengthened their sense of solidarity, which was of extreme importance when the ethnos as a whole or in part came under threat.

\subsection{Political and Social Organization}

The shape of the social and political organization of a particular community is of fundamental importance to understanding its history. Discussing this subject, however, is akin to walking through a minefield. There are numerous pitfalls awaiting any researcher who deals with historical societies. The first of these is terminology. Every scientific language needs one, but it is hard to resist the impression that today's language of description of past social structures has undergone far-ranging deconstruction. As a result of criticism of the evolutionary paradigm, the category of the state in particular has lost much of its significance. First of all, it has ceased to be an acid test for the level of development of a specific community. The state is also no longer perceived as a

Xiongnu's military policies (especially the use of large-scale cavalry) that the Han were able to introduce a bellicose foreign policy (Di Cosmo 2002, 229-247). Likewise, in the times of the late Sui Dynasty and early Tang Dynasty (7th century), resistance to Turkish invasions became effective following the creation of elite cavalry units, which were fully "Turkified", meaning they fought using the methods as the steppe-dwellers. (Li Jinxiu 2014, 66-74).

26 Szymański 1973, 126-131.

27 Tryjarski 1975a, 519-520. Cf. also Chapter 7 of the present book. 
necessary institution, nor as a guarantee of a community's successful continuation. Human communities have sometimes achieved a high level of development (e.g., the Greek polis) despite the lack of distinct state structures. ${ }^{28} \mathrm{We}$ find ourselves at this point entering into a hopeless discussion on the definition of a state, i.e., a discussion that has no chance of being resolved. We can accept the pragmatic observation that an excessive widening of the definition of a state leads to the conclusion that any political organization of a human community is essentially a state, which results in a complete loss of the term's value as an analytical category. ${ }^{29}$ However, it is also impossible not to notice that a precise definition of the term is extremely difficult, if not impossible. A universal definition covering all civilizations and epochs most likely simply does not exist. Such the case, phrases like 'pre-state community' and 'pre-state organism' lose their meaning entirely.

A separate issue is the problem of statehood in nomads. This discussion has been ongoing for many decades, and seems to have yielded two basic positions. The representatives of the first of these positions are inclined to claim that nomadic communities are not capable of creating states. At best, they form empires, which are externally dangerous and perfectly suited for expansion and exerting pressure on neighbouring political entities, but internally possess a loose federal or tribal structure. ${ }^{30}$ Representatives of the opposing view believe that nomads are not inferior to other communities when it comes to their capacity for state-building. ${ }^{31}$ This view can be maintained only with a very broad definition of the category of the state, which, especially in view of the fragmentary nature of sources, may result in almost every political organism of nomads being considered a state. It seems that taking into account the specificity of the steppe world, the least controversial solution would be to use the category of 'early state', i.e., a political structure with a clearly defined centre, in which all the institutions typical of a mature state apparatus have not yet been created, or are merely embryonic in character. ${ }^{32}$ Such transitional

28 Bravo, Wipszycka 1988, 133-138; Bondarenko, Korotayev, Kradin 2003, 6. The authors of the latter study remind us that organisms of the polis-civitas type were neither merely an ancient phenomenon, nor a European one. Moreover, they seem to have been quite numerous, meaning they cannot be viewed as a systemic anomaly.

29 Tymowski 2009, 12-13.

3о Markov 1976, 312-313; Barfield 1992, 7-8; 1993, 149-151; Kradin 1992, 152; 2002, 244-246; Kradin, Skrynnikova 2006, 5 o.

31 Sneath 2007, 21-37.

32 Claessen, Skalník 1978, 3-27; Khazanov 1978a, 77-92; Skalník 1978, 597-618; Claessen, Skalník 1978a, 619-635; Khazanov 1981, 155-175; Claessen, Skalník 1981, 469-510; Khazanov $1984,228-233,295^{-302}$. The concept of an early state in nomad societies is sometimes opposed with the concept of a supercomplex chiefdom, used to describe the structure of 
formations were created relatively often by Eurasian steppe nomads. A feature specific to them, however, was their lack of stability. The status of a mature state seems to have been achieved only by nomadic cultures that had already moved off the steppe. ${ }^{33}$

In modern academic discourse, use of the categories of 'clan' and 'tribe', once very important for describing social and political structures, have been largely repudiated. Together with these terms, the notion of 'clan-tribal system' and 'patriarchal and clan system' have also lost their value. This terminological crisis seems to have resulted, at least to some extent, from the abandonment of the evolutionary paradigm. So-called pre-state societies, whose political existence was framed within one of the above-mentioned 'systems', were frequently compared to societies 'already' functioning within state structures. Nevertheless, notions like 'clan' and 'tribe', condemned by some researchers, continue to be commonly used. In fact, we seem to be dealing not so much with their abandonment, as with their redefinition. ${ }^{34}$

Written sources provide much information on the sociopolitical organization of historical communities, but these pronouncements are tainted by subjectivism and bias - which in the case of nomadic communities is extremely common - having been prepared by foreign authors, i.e., individuals not belonging to the community described. However, this merely burdens the researcher with the obligation of having to try to decipher the conceptual apparatus used in a specific text and, afterward, reconstructing a fragment of the social reality it describes. The existence of certain notions does not, of course, determine their actual meaning. In other words, the fact the a specific author notices the presence of certain sociopolitical organizational units, the name of which allows us to associate them with categories commonly used in anthropology (e.g., 'clan' and 'tribe'), does not in itself determine the basis of these

the so-called steppe empires. The latter were not states, because they had not yet managed to create a fully developed administrative apparatus, only its foundations (cf. Kradin 2002a, 372-373; Kradin, Skrynnikova 2006, 50-51). It should be noted, first of all, that such a definition of a supercomplex chiefdom makes it a concept very close to that of an early state. Nikolai Kradin and Tatiana Skrynnikova called it a 'state prototype (proobraz)'. This means in practice that it is very difficult to distinguish between the two political organisms. A supercomplex chiefdom seems to have been an entity that could only exist in scholarly discussions, as another 'degree of abstraction' between the well-rooted categories of chiefdom and an early state.

Khazanov 1984, 228-232; Di Cosmo 1994, 1115-1118; 1999, 20-28.

34 Lindner 1982, 689-711. The researcher assumes that a nomadic tribe is simply a political organism in which blood kinship is no longer meaningful. The tribe is understood as the basic political structure of nomads. Its size is unimportant; the empires of the European Huns and the Ottoman Turks are tribes as well. 
organizational units. ${ }^{35}$ In addition to political and historical factors par excellence, such as common interest as a factor leading to the formation of alliances between previously separate groups, or simply the conquest of the weaker by the stronger, we should at least in theory allow for the principle of kinship. This concept most likely did not provide the foundation for large political organisms. The 'idiom of kinship' in these was in fact a tool for communicating the order created within the political process. The terminology associated with this notion was therefore not an organizing principle, but a secondary phenomenon, reflecting the existing system of interests and hierarchies. It seems, however, that at the lowest, most basic levels of social organization, real blood relationships, rather than fictitious one, played a very important role among nomads. Finally, it is worth remembering that in the political organisms of steppe people, real (blood) kinship or affinity sometimes acquired political significance as a tool for consolidating alliances between individual aristocratic families. ${ }^{36}$

The Pechenegs will therefore be described, above all, as a political organism shaped and modified by historical events. Groups of people of different origins could belong to this organism; however, the principle that united them was political in character. In order to understand this principle, it is necessary to refer to primary sources, supplemented by comparative materials concerning other Eurasian steppe groups.

A fortunate circumstance is the fact that the sociopolitical organization of the Pechenegs was described in some detail in Constantine VII Porphyrogenitus' De administrando imperio. An additional propitious factor is the emperor's keen interest in the sociopolitical structures of nomads, resulting from his plans in relation to them. This data is probably quite reliable, although it does not contain the native names of the individual units of the Pechenegs' system of social organization, but instead uses (sometimes quite surprising) Greek terms. This means that it is necessary to take a closer look at them and then compare them with what is generally known about the sociopolitical systems of steppe peoples.

35 In one of his works, Peter B. Golden seems to reject David Sneath's criticism of traditional concepts. Golden is right that some of them simply come from written sources, but this does not mean they do not require detailed analysis and, if necessary, redefinition. Sneath, on the other hand, sometimes seems to assume that the mere use of traditional names of socio-political entities by a particular researcher is tantamount to accepting their former meaning, related to now outdated concepts, uncritically. Golden 2011, 17 (n. 1); Sneath 2007, 2.

36 Markov 1976, 310-311; Lindner 1982, 696-70o; Khazanov 1984, 138-144; Barfield 1992, 26-27. 
To describe all Pechenegs and individual units of their political organism

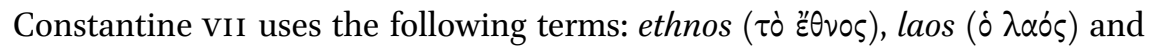
genea $(\dot{\eta} \gamma \varepsilon v \varepsilon \dot{\alpha})$, while for units of their territorial organization he uses: thema ( $\tau \dot{\partial} \theta \dot{\varepsilon} \mu \alpha)$ and meros ( $\tau \dot{o} \mu \varepsilon \dot{\varepsilon}$ pos).

Clarifying the scope of the meaning of the first of these terms does not pose too great a problem. Constantine viI uses ethnos [हैق $\theta 0 \varsigma$ ] when he means the whole people. In the first chapter of De administrando imperio we read:

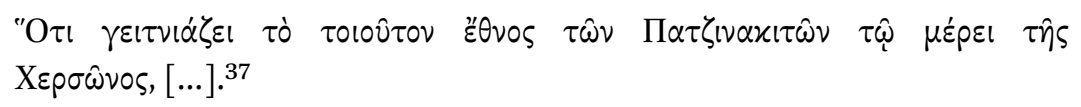

This nation [हैق Cherson, [...].

Similarly, in the Title of Chapter 37:

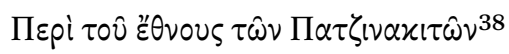

Of the nation [ $[\ddot{\theta} \theta 0 s]$ of the Pechenegs

The second term, $\delta \lambda \alpha \delta$ s, is somewhat more difficult. It is used four times in relation to the Pechenegs, for the first time in Chapter 4:

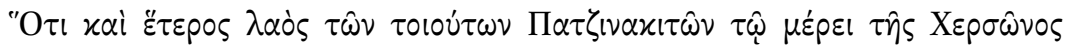
$\pi \alpha \rho \alpha \dot{x \varepsilon \varepsilon v \tau \alpha l, ~}[\ldots] .^{39}$

Yet another folk [ $\lambda \alpha$ ò $]$ of these Pechenegs lies over against the district of Cherson [...].

Then again in Chapter 8:

"O

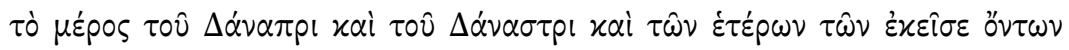
$\pi \circ \tau \alpha \mu \omega \hat{\nu} .{ }^{40}$

\footnotetext{
37 DAI, I $25^{-26}$ (p. 48/49).

38 DAI, XXXVII 1 (p. 166/167).

39 DAI, VI $2-3$ (p. 52/53).

40 DAI, VIII $5^{-7}$ (p. $\left.54 / 55\right)$.
} 
In the region of Bulgaria also is settled a folk [ $\lambda \alpha \alpha_{\varsigma}$ ] of the Pechenegs, toward the region of the Dnieper and Dniester and the other rivers of those parts.

\section{In Chapter 37:}

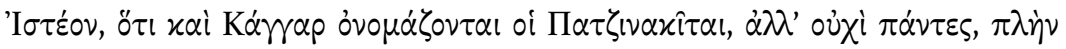

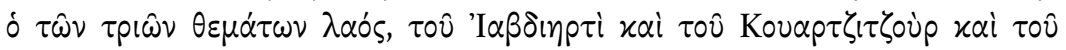

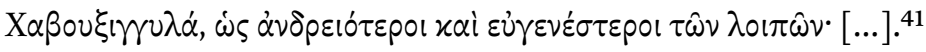

The Pechenegs are also called 'Kangar', though not all of them, but only the folk $\left[\lambda \alpha \dot{o}_{\varsigma}\right]$ of the three provinces of Iabdierti and Kouartzitzour and Chabouxingyla, for they are more valiant and noble than the rest [...].

The term also appears a second time in Chapter 8. This time Constantine Porphyrogenitus quotes a statement about the Pechenegs by the Magyars, who say 'they cannot fight them, because their country is great and their people numerous' $\left[\lambda \alpha \dot{o}_{\varsigma} \pi 0 \lambda \dot{v} \varsigma\right]{ }^{42}$ The juxtaposition of contexts in which the term $\lambda \alpha o$ s is used seems to indicate that the scholarly emperor applies it in a rather inconsistent manner. It may mean a part of the Pecheneg people, but it may also mean its entirety. To some extent it seems to be synonymous with the

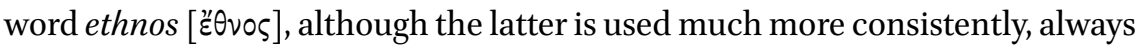
towards the whole people.

An analysis of the third term, $\dot{\eta} \gamma \varepsilon v \varepsilon \dot{\alpha}$, brings interesting results. In Chapter 37 , we find the following passage:

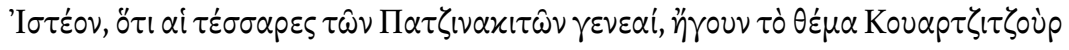

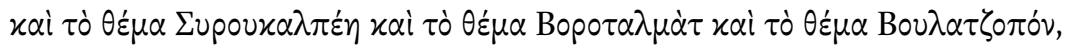

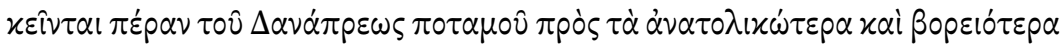

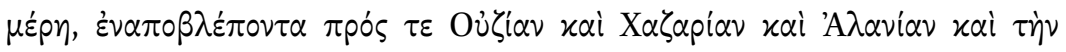

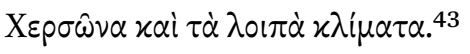

\footnotetext{
41 DAI, XXXVII 68-71 (p. 170/171).

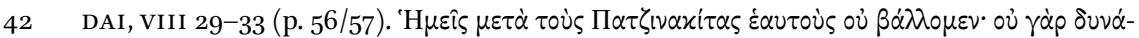

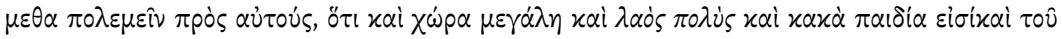

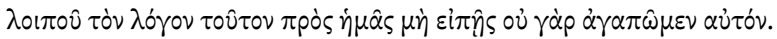


Four clans [ $\gamma \varepsilon v \varepsilon \alpha i]$ of the Pechenegs, that is to say, the province of Kouartzitzour and the province of Syroukalpei and the province of Borotalmat and the province of Boulatzopon, lie beyond the Dnieper river towards the eastern and northern parts that face Uzia and Chazaria and Alania and Cherson and the rest of the Regions.

The author further states that four other geneai live in an area west of the Dnieper River. In the light of the above example of geneai (sg. genea), it should be recognized as a higher unit in the Pechenegs' social organization. Each is clearly determined by territory and has its own name. The term also appears in a text that described events from the mid-11th century, i.e., 100 years after Constantine Porphyrogenitus' account. In the Chronicle of John Skylitzes, we read:

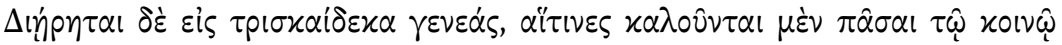

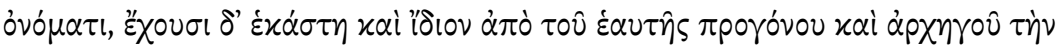
$\pi \rho \circ \sigma \eta \gamma о \rho i \alpha \nu x \lambda \eta \rho \omega \sigma \alpha \mu \varepsilon \dot{\varepsilon} \eta{ }^{44}$
\end{abstract}

They [Pechenegs] are divided into thirteen tribes [ have the same name in common but each has its own proper name inherited from its own ancestor and chieftain.

This extremely interesting information poses a number of difficulties for the researcher. We cannot assume in advance that Constantine Porphyrogenitus and John Skylitzes are using analogous terminology. This need not be excluded, but there are reasons to remain sceptical. The older author mentions eight large units in the Pecheneg organization, while the younger one lists 13. The scholarly basileus does not know about the alleged origin of the names of these units from the names of some ancestor-protagonist.

The term genea in the context of the sociopolitical organization of the Pechenegs also appears in the Scylitzes Continuatus. Here it refers to a later period, when the steppe people already inhabited the Balkan provinces of Byzantium. The author claims that the entire population was divided into geneai and fratriai (sg. $\varphi p \alpha \tau p i \alpha$ ), but does not give their number. ${ }^{45}$ This extremely laconic information allows us to assume that the last term, not mentioned anywhere else in relation to the Pechenegs, may correspond to some social organizational unit below the level of genea.

44 Io.Scyl., 455 (v. 34-37). Cf. Wortley 2010, 426.

45 Scyl.Cont., 107. 
The discrepancy between the information in the writings of Constantine VII and John Skylitzes can be explained by the time interval between the two accounts. Over the course of this roughly 10o-year period, the Pechenegs experienced a series of severe disasters, which likely affected, if not devastated, their sociopolitical organism. ${ }^{46}$ Geneai - its highest level in the times of Constantine VII - may simply have ceased to exist or underwent far-reaching transformations in the first decades of the 11th century, after the series of defeats the Pechenegs suffered in battles with the Uzes. They would, therefore, not be the same as the 13th geneai from the period preceding the Pechenegs' departure from the Black Sea steppe, which is the subject of Skylitzes' account. The author does give the names of only two of these geneai: Pagumanis

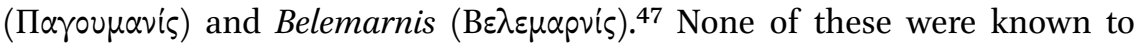
Constantine Porphyrogenitus.

References to comparative materials only provides a half-way solution. In general, it is assumed that there were two or three levels of socio-political organization among nomad peoples, composed of relevant taxonomic units. ${ }^{48}$ Among the Altai steppe people there was a unit called a bone (Tur. süyük söyük süök, Mong. yasun), synonymous with the Slavic ród or English clan. Its members claimed shared family ties between them and their descent from a common ancestor. The last circumstance was to supposed ensure that its boundaries were precisely defined, so it was thus originally an agnatic unit, quite closed and very close-knit, and therefore stable. ${ }^{49}$ In addition to the bones of nomadic societies, there was also a larger unit of social organization called an omuq in Old Turkic, and in Mongolian obo $\gamma$. Its equivalents is the notion of tribe (Ger. Stamm). The omuq/oboy, unlike bones, however, was a much less stable entity. Blood relations did not play an important role in it as a binding force, and its continuation was determined by common economic and political interests. It could therefore disintegrate or merge into larger organizational units much more easily than a bone. ${ }^{50}$ Unfortunately, the relationship between the two entities is unclear. This is because members of the same bone could simultaneously belong to various $\mathrm{Omuq} / \mathrm{obo} \gamma \cdot{ }^{51} \mathrm{In}$ addition, according to some

46 Cf. in particular Chapter 6 of the present book.

47 Io.Scyl., 456 (v. 59-6o).

48 Moszyński 1996, 53; Khazanov 1984, 132-138. The latter scholar calls them communities of primary/second/third order. However, not all nomadic communities featured all three levels of organization. It is usually assumed that the existence of three levels of social organization is reflective of state organisms. Cf. Carneiro 1981, 45-46.

49 Kotwicz 1949, 16o-161; Kałużyński 1970, 39-40; Tryjarski 1975a, 567. Cf. Pritsak 1952, 6o.

50 Kotwicz 1949, 161; Kałużyński 1970, 40; Tryjarski 1975a, 567.

$5^{1} \quad$ Kotwicz 1949, 161; Krader 1963, 324. 
researchers, only part of a community, that with an aristocratic background, could be identified as belonging to a particular bone. ${ }^{52}$ Tatiana Skrynnikova, in her description of the sociopolitical structure of the Mongols in the times of Genghis Khan and in the period immediately preceding him, posited the existence of two types units organizing an ethnos: urug and obog. The first one is described by the researcher as lineage, the second is a clan. A combination of urug formed units of a higher order, such as an obog, but they could also easily detach themselves and give rise to a new clan. ${ }^{53}$ Thus, the observations of the Russian researcher correspond to the common conviction among researchers of nomadic societies of the fundamental importance of family structures in the sociopolitical organization of nomads. This is because the daily life of nomads takes place within these units. They also form the basis for their economic existence as a common nomadic group and for grazing cattle. However, they acquire political importance only within larger units. ${ }^{54}$

References made in these general observations to source data leads to the cautious conclusion that the genea as a taxonomic unit in De administrando imperio may be identical to that of John Skylitzes. The failures experienced by the Pechenegs at the turn of the 1oth and 11th centuries most likely led to the devastation of the largest units of their political organization. In the new conditions, however, the place of geneai was not taken by smaller units, which we will call 'clans', but rather by a transformation of the structure of the whole ethnos and the emergence of 13 new geneai, instead of the previous eight.

The information in De administrando imperio indicates a strong link between the sociopolitical organization and territorial divisions of the Pechenegs, which was already noted above. Their entire territory consisted of eight units, each with a name identical to that of a genea. These units were described by Constantine viI Porphyrogenitus as thema ( $\tau \dot{0} \theta \varepsilon \dot{\varepsilon} \mu \alpha$ ), as we read again in Chapter 37 of his work:

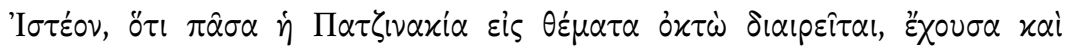

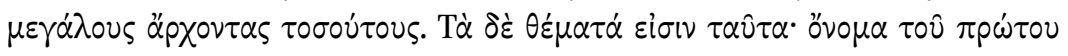

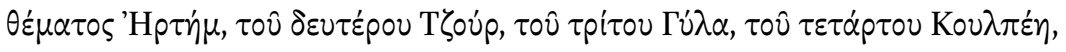

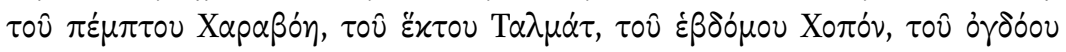

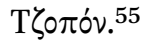

52 Sneath 2007, 171-172.

53 Skrynnikova 2011, 458-459. Cf. also Igor de Rachewiltz's comments in: 2004, I, 249-25o.

54 Moszyński 1996, 52-53; Khazanov 1984, 126-128 (the scholar does not use the term 'family', but instead 'primary kin group'); Szyjewski 2001, 414. DAI, XXXVII 15-19 (p. 166/167). 
The whole Patzinacia is divided into eight provinces $[\theta \dot{\varepsilon} \mu \alpha \tau \alpha]$ with the same number of great princes. The provinces $[\theta \varepsilon \dot{\varepsilon} \mu \tau \dot{\alpha}]$ are these: the name of the first province [ $\theta \varepsilon \dot{\varepsilon} \mu \alpha \tau$ ] $]$ is Irtim; of the second, Tzour; of the third, Gyla; of the fourth, Koulpeï; of the fifth, Charaboï; of the sixth, Talmat; of the seventh, Chopon; of the eighth, Tzopon.

A researcher's interest is sure to be awakened by the use of the Byzantine term thema by Constantine VII to name a territorial unit of the Pechenegs' lands. By the mid-1oth century, thema already had a long history. The beginning of the reform that made it the basis of Byzantium's administrative and military structure is traditionally attributed to Emperor Heraclius. By the turn of the 9 th and 1oth centuries, the thema system had reached its mature form. ${ }^{56}$ During the reign of Constantine VII it was still the foundation for the functioning of the state, so use of the term to describe divisions in the territory of the Pechenegs could not have been merely accidental. This seems all the more improbable given the fact that the author uses different terms in relation to the territorial organization of other peoples described in De administrando imperio. Describing the relationship between the Alans and the Khazars, he states:

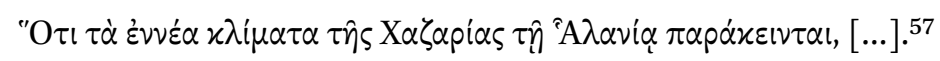

Nine regions $[\varkappa \lambda i \mu \alpha \tau \alpha]$ of Chazaria are adjacent to Alania $[\ldots]$.

If the term thema is applied to the territorial organization of the Pechenegs, it should be given clear, distinctive features. The question then arises: what did Constantine vir intend to focus on? The state of our knowledge does not allow us to go beyond the sphere of conjecture. However, it seems that two possible explanations need to be pointed out. First, the basileus wanted to highlight the very strong relationship between the military and territorial organization of the Pechenegs. Such an assumption is validated by other information given about them as well as by comparative data about the culture of steppe peoples. Second, the learned emperor may have been particularly interested in demonstrating the efficiency and coherence of the Pechenegs' means of organization, which could serve as an analogy for the administrative system of the Byzantine Empire. If we take into account the fact that Constantine viI linked specific political plans with the Pechenegs, which he expressed in the first chapter of

$5^{6}$ Ensslin 1964, 356-357. Ostrogorski 1967, 215; Lilie 1984, 27-39, 190-201; Kazhdan 1991a, 2034-2035. On the meaning of the term 'thema': Koder 1990, 155-165. 
his work, then it is not too difficult to find a motive for such a course of action. This does not mean, however, that the Emperor distorted reality for the sake of his diplomatic doctrine.

Constantine VII also mentions the existence of lower-level territorial organization units among the Pechenegs. This is indicated by the following passage:

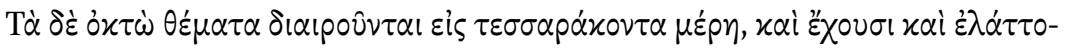

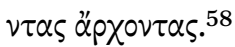

The eight provinces [ $\theta \varepsilon \dot{\varepsilon} \mu \alpha \tau \alpha]$ are divided into forty districts [ $\mu \dot{\varepsilon} \rho \eta]$, and these have minor princelings over them.

If we take into account the fact that the tribe (genea) corresponded to the thema on the level of the Pechenegs' social organization, then, based on anal-

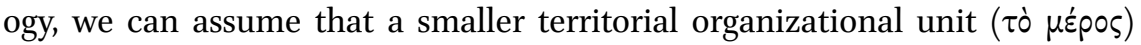
should correspond to some social unit. Unfortunately, we do not know its name, which makes it very difficult to find analogies among the data concerning other nomadic peoples. It cannot be ruled out that it corresponded to the clan.

In the mid-1oth century, the Pecheneg ethnos therefore consisted of eight large socio-political units, which in turn were broken down into forty smaller ones. Within each genea there were probably five smaller units. ${ }^{59}$ This type of organization was overlapped by the territorial division of the whole of Patzinacia, according to which four geneai lived in the area west of the Dnieper River (Giazichopon, Kato Gyla, Charaboï, and Iabdiertim) and the remaining four to the east (Kouartzitzour, Syrukoulpeï, Borotalmat, and Boulatzopon). ${ }^{60}$ This division, whose axis was the Dnieper, very much resembles the two-wing toliš-tarduš system, attested for many steppe-based political organisms. It is also a typical element of the military organization of nomadic groups. ${ }^{61}$

It is difficult to say how long the Pecheneg sociopolitical organization existed in the shape outlined here. It is highly probable, however, that the events of the turn of the 1oth and 11th century, i.e., the Pechenegs' failures in their fight against Rus' and, above all, pressure from the Uzes, seriously strained it. The loss of settlement areas to the east of the Dnieper most certainly compromised

58 DAI, XXXVII $32-33$ (p. 166/167).

59 A similar interpretation was adopted by Pletneva 1958, 192.

6o DAI, XXXVII 34-45 (p. 168).

61 Tryjarski 1975a, 571; Pritsak 1975, 218. 
its territorial basis, which was then accompanied by demographic losses. These phenomena caused the aforementioned transformation of the geneai.

Fragmentary source data makes it difficult to describe relations within particular units of the Pechenegs' social organization. However, we can assume that the same factors that led to social stratification within other nomadic ethne were also influential here. Despite the formal egalitarianism strongly emphasized and cultivated among nomads, ${ }^{62}$ the political primacy of certain individuals and sub-groups is clearly visible among them. The sources of such a state of affairs can be found in two phenomena: differences in terms of wealth and a hierarchy of prestige in terms of both individuals and entire groups. ${ }^{63}$ In the case of nomadic communities, the source of differences in wealth was mainly the size of herds. The phenomenon of land ownership was practically non-existent on the steppe. ${ }^{64}$ Wealth, although important as a determinant of prestige, is not the only source of it. A telling example is that of Temujin, who was born the heir of several yurts, and later stripped of all his property and degraded to the status of an outcast, but died as the creator of an enormous empire. His life is therefore the best illustration of the relative value of wealth and the immense role of charisma in the life of a steppe leader. ${ }^{65}$

The mechanism of significant fluctuations in wealth in nomadic communities resulted, according to experts on the subject, from the specificity of the steppe economy, which was based on pastoralism. Natural disasters, among which very harsh winters were most important, could significantly reduce the size of herds. For rich nomads, this usually resulted in a significant reduction in their wealth, while for those of average and lesser means it meant the loss of their means of subsistence and a fall to the lower reaches of the social scale. ${ }^{66}$ Robbery was also a phenomenon that brought about significant changes in ownership. As a result of regular looting raids, steppe people could get rich or,

62 Moszyński 1996, 34-35; Khazanov 1984, 153-157.

63 Cf. Pritsak 1952, 52-53. The hierarchy of tribes proposed by the Pritsak concerns mainly large steppe empires. Therefore caution is required when applying it to smaller political organisms. Cf. Khazanov 1984, 152. He points to private ownership of livestock and one's place in the social structure as sources of social diversity.

64 Markov 1976, 298-30o; Khazanov 1984, 123-126; Nowicka 2001, 327, 329.

65 The Secret History of the Mongols describes Temüjin as one with '[...] fire in his eyes, [...] light in his face'. This type of formulation is said to be a typical topos in Mongolian oral literature used to indicate a person with extraordinary intellectual and spiritual qualities. Rachewiltz 2004, I, 14, 24, 327-328. It is also characteristic of a charismatic personality. Charisma (Turkic: qut, Persian: hvarena) was often imagined and presented as a ray of light. Cf. Golden 2006, 44.

66 Moszyński 1996, 36; Khazanov 1984, 73-76; Gumilow 1997, 12-13. 
in the case of an attack by another ethnos, lose almost everything. ${ }^{67}$ Military activity triggered another noteworthy phenomenon. As a group undertaking, military activity required the existence of an efficient command that would ensure its success. A similar state of affairs promoted talented nomads, whose military and plundering successes had becoming a source of considerable prestige and, consequently, an opportunity to attain political power. We are dealing here with a phenomenon that Omeljan Pritsak described as 'charisma'. As he achieved successive victories, a leader endowed with such charisma gathered faithful and devoted warriors around him. In this way, a relationship was formed that resembled the Germanic Männerbund. The success of the leader was interpreted in religious terms as a special gift and mandate from Heaven (Tängri). The mechanism described by Pritsak is extremely important for understanding the origins of many steppe empires. Their creators were often small groups of nomads headed by a charismatic leader. ${ }^{68}$

As a result of the impact of the combination of factors described above, a group of nomads was formed who enjoyed greater importance and respect than other members of their ethnos. Social and economic relations of this type may have resulted in a form of clientelism. ${ }^{69}$ An additional factor conducive to the enlargement of a dependent population were invasions, during which prisoners of war were abducted. ${ }^{70} \mathrm{~A}$ large part of these prisoners was usually sold off, but those who remained among the nomads could soon become members of the new community, although they remained dependent on their patrons. ${ }^{71}$

From Pritsak's research we know that the hierarchy of tribes (the second phenomenon of interest to us) consisted of four traditional categories: ruling tribes, voluntarily affiliated (brother-in-law) tribes, tribute-paying tribes, and finally, conquered tribes, which were deprived of all rights. ${ }^{72}$ As has already

67 Moszyński 1996, 36 .

68 Pritsak 1952, 51; 1988, 750, 751-753; Golden 2006, 42-44; Geary 2012a, 47.

69 Moszyński 1996, 29-30; Szymański 1979, 93; Nagrodzka-Majchrzyk 1985, 82-83; Khazanov 1984, 157-159.

70 Moszyński 1996, 30; Dąbrowski 1975, 103; Szymański 1979, 93.

71 Cf. the very interesting example of a merchant from Viminatium described by Priscos of Panion. Abducted by the Huns, he was to become the property of Onegesios, Attila's trusted minister, as part of the booty. Later, however, he stood out in battles with the Romans and the Akatziri, regained his freedom and married a barbarian woman. According to Byzantine diplomat's accounts, he valued his status among the barbarians much more than his former position in the empire. He also remained, what is significant,

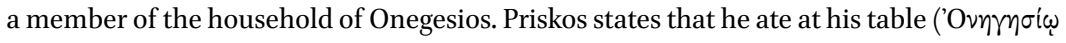

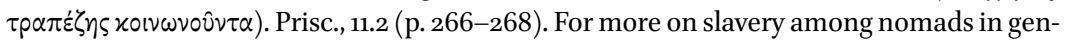
eral: Khazanov 1984, 16 o.

Pritsak 1952, 52-53; Swoboda 1978, 412; Tryjarski 1975, 302. 
been discussed, the shape of this hierarchy was a consequence of the history of a given steppe-based political organism. The founding groups, those which had been part of it the longest, enjoyed the greatest prestige. The combination of phenomena described above determined the shape of relations within a given political organism.

Despite the relative scarcity of sources, it seems that some of these general observations can also be applied to the specific case of the Pechenegs. The fact that there were property differences within their communities can be deduced from accounts associated with the Jayhānī tradition. These authors (al-Bakrī, al-Gardīzī and al-Marwazī) agree that the Pechenegs were wealthy, possessing large flocks, gold and silver dishes, and silver belts and weapons. ${ }^{73}$ This affluence was most likely not spread evenly among all the members of the ethnos. The lion's share was probably in the hands of the elite. This assumption seems to confirmed by information from Constantine viI Porphyrogenitus, who in the second chapter of De administrando imperio reports that the Pechenegs sold horned cattle, sheep and horses to Rus'. ${ }^{74}$ In another place he mentions the existence of a commodity exchange operated by the inhabitants of Byzantine Kherson for purposes of trading with the Pechenegs. ${ }^{75}$ Both examples indicate quite clearly that surpluses occurred in the Pechenegs' economy and that these later became objects of trade. In all probability such surpluses belonged to the richer members of the group, as it is hard to imagine that an average member of the community would sell part of his herd, which provided the means of existence for him and his family. A surplus sufficient to allow for trade was thus most easily obtained by the owner of a larger herd of livestock.

Archaeological materials provide weak documentation of the differences in wealth among the Pechenegs. Their material culture is known mainly from the inventories of burial sites, which raises the question of to what extent funeral practices reflected differences in social status and wealth. Funeral ceremonies usually provide an opportunity to manifest the social prestige of the deceased. In this respect, nomads were no exception, although their attempts to conceal the burial site of significant personalities for fear of profanation and robbery have also been confirmed. ${ }^{76}$ Material traces of these burial sites, in spite of hav-

73 Gardīzī: Martinez 1982, 152; Göckenjan, Zimonyi 2oo1, 165. Bakrī: Kunik, Rozen 1878, 59; Göckenjan, Zimonyi 2001, 222. Marwazi: Minorsky 1942, 33; Göckenjan, Zimonyi 2001, 25o. Zakhoder 1967, 74 .

74 DAI, II 6-8 (p. 5o).

75 DAI, VI (pp. 52-53); LIII 530-532 (p. 286). Cf. the part of this chapter dedicated to the economy.

76 Roux 1984, 263-280; 1988, $5^{28}$. The researcher does not question the fact that some steppe peoples (e.g., Mongols) concealed graves out of fear of robbery and desecration, but he 
ing been protected against their contemporaries, nevertheless remain. In the case of the Pechenegs, thus far only so-called 'secondary' burial mounds have been discovered, i.e., those dug into the banks of old burial mounds, usually from prehistoric eras. The inventory of steppe grave sites is generally relatively poor. Nevertheless, some researchers have tried to prove the existence of distinctions in property among the Pechenegs on their basis. Svetlana A. Pletneva has pointed out that more valuable weapons (e.g., sabres) have been found in only a few Pecheneg grave sites. ${ }^{77}$ Economic differentiation is also said to be evidenced by differences in the amount of horse remains discovered in graves. A full skeleton, a very rare finding, would be testimony to great wealth, while an incomplete skeleton would indicate the lower status of the person buried. ${ }^{78}$ Interpretations of this kind, however, are not convincing. This data seems to indicate in fact a rather low level of economic diversification among the Pechenegs. In the light of the material remains of funeral rituals, they appear to have been a rather egalitarian society with small, relatively poorly manifested social differences among its members.

Interesting data concerning the nature of relations within the Pecheneg community can be found in the writings of al-Bakrī. He states that the Pechenegs made a proposal to prisoners from Byzantium, but also from other lands, to stay with them as equal members of their community who had the right to take one of its women as a wife. If he rejected such an offer, they would take him safely to the border of their lands. ${ }^{79}$ The quoted fragment does not necessarily come from the lost work of al-Jayhānī, as is indicated by the lack of an analogous passage in the works of al-Gardīzì, al-Marwazì and ibn Rusta. It most likely concerns the Black Sea period of the Pechenegs' history. Pletneva considers this report to be proof of the existence of nomadic feudalism among them, ${ }^{80}$ but it would be safer to talk about some form of clientelism. A prisoner who did not have any means of subsistence was only formally made a full member of the community. His continued existence depended on his patron, who could provide him with decent living conditions for the services he received from him. It is also worth considering whether the Pechenegs

points out that their location was often widely known because they were places of worship. According to Roux, workers who worked on the construction of graves and funeral rites were killed because they were sullied.

77 Pletneva 1958, 197; 1981, 215 .

78 Pletneva 2003, 158. Cf. Garustovich, Ivanov 2001, 69, 82-93 (the data refer to areas east of Volga); Atavin 2008, 78 (interprets this similar diversity of funeral rites as a deliberate manifestation of a separate ethnic identity).

79 Bakrī: Kunik, Rozen 1878, 6o; Göckenjan, Zimonyi 20o1, 223-224.

8o Pletneva 1958, 193 . 
made such an offer to every refugee who came to them. It seems reasonable, although not supported by the source data, to assume that such an offer was mainly addressed to those with special skills who for some reason were valuable to the Pechenegs. ${ }^{81}$ Unfortunately, we are not able to go beyond conjecture about what kind of qualifications would make them so valuable for the nomads. Perhaps they were highly specialized craftsmen or possessed some kind of military skills that were not commonly found among the Pechenegs. ${ }^{82}$ Another hypothesis should also be taken into account, according to which the prisoners were individuals thanks to whom the Pechenegs would be able to establish contact with neighbouring states. Their origins guarantees a knowledge of a potential political partner, and they could serve as translators or intermediaries in the formation of alliances. ${ }^{83}$

Most importantly, however, al-Bakri's account provides evidence that seems to confirm the existence of a group of wealthy people capable of providing for the subsistence of a valuable prisoner-of-war. The resulting dependence, in turn, opened the path for the creation of a kind of patron elite that could increase its political significance thanks to the support of its clients.

At the other end of this social system were the people dependent on their patrons. The appearance of such people among the Pechenegs resulted from multiple causes. Some clients, as we have seen, were former prisoners-of-war, while others were impoverished steppe-dwellers.

There is no doubt that both large and small units in the Pechenegs' system of social organization had their own leaders. Constantine VII claims they were

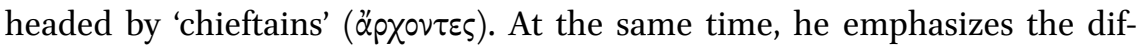
ference in quality between them, adding the nicknames of 'great chieftains'

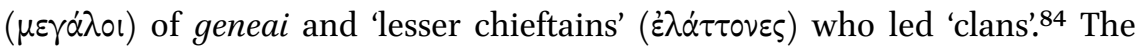
Emperor also describes the mechanism of succession within larger units. We learn that upon the death of the chief, power passed into the hands of his cousin ( $\dot{\delta} \dot{\xi} \xi \dot{\alpha} \delta \varepsilon \lambda \varphi \circ \varsigma)$ or son of his cousin ( $\dot{\delta} \pi \alpha \hat{\imath} \varsigma \dot{\xi} \xi \alpha \delta \dot{\varepsilon} \lambda \varphi \circ v)$. Thanks to a similar procedure, the learned emperor claimed, the position of leader was not held by just one branch of the clan, but also by collateral branches; however, power could never be fall into the hands of a stranger tribe. ${ }^{85}$ This system of inheritance was not only characteristic of the Pechenegs. Some similarities can be observed

\footnotetext{
81 Tryjarski 1975a, 575 .

82 Tryjarski 1975 a, 575 .

83 Tryjarski 1975a, 575. It is known that in their dealings with the imperial court, the Huns were helped by Romans from the provinces they had conquered. Maenchen-Helfen 1973, 106-107.

84 DAI, XXXVII 15-16, 32-33 (p. 166/167).

85 DAI, XXXVII 24-32 (p. 166/167).
} 
with the 'lateral sucession' system (udel'no-lestvichnaia sistema), which existed among the Blue Turks. It stipulated that supreme power over the whole empire would be inherited not by the leader's son, but by his younger brother, and by the oldest fraternal nephew from his younger paternal uncle. While waiting for the throne, 'princes of the blood', i.e., members of the royal Ashina clan, were to manage districts assigned to them. According to Lev Gumilev, this system was introduced in the 6th century when the great Turkic Khaganate was created. Its prototype was a system of inheritance known from the second century in southern Xiongnu. ${ }^{86}$ It was introduced namely to prevent fratricidal fights between individual princes of the blood. This system both provided members of the Ashina clan with an appropriate standard of living, and gave them hope for the assumption of supreme power. While there are obvious differences between the Turks and Pechenegs, the system observed in the latter most likely played a similar role. In spite of its clear process for closing off tribal power, this type of succession guaranteed that the political primacy of one branch of the clan would be limited, while at the same time creating opportunities for another branch of the clan to assume leadership.

Another problem is the question of the nature of the power of tribal leaders. During their life-long authority over a genea did they have to take into account the opinions of other members of the community, perhaps gathered in elementary political institutions? It seems that the answer to this question is affirmative. Despite the issues outlined above, which allow us to see signs of social differentiation, the Pechenegs appear to have been quite an egalitarian community, in which the largest part of the population possessed an average material status and a similar level of prestige. This would have meant that any decision concerning the whole community would require the consent of all its free members. A similar state of affairs was the raison d'être for institutions like the public gathering. However, within such an institution or alongside it,

86 Gumilev 1966, 213-214; 1993, 56-59; Kychanov 2010, 127-129. In fact, in the Xiongnu empire after the First Civil War (6о BCE), direct-line (father to son) and lateral (elder to younger brother) systems of inheritance were used interchangeably. Barfield 1992, 71-77 (on succession in Xiongnu), 133-138 (on succession in Turks). The latter seems to have treated the mechanism of succession as the outcome of purely political factors and the principles of inheritance known to steppe people. Khazanov 1975, 195-199 (in the case of the Scythians the author assumes the dominance of the principle of succession 'from father to son', in the case of Xiongnu he takes a position similar to T.J. Barfield). Finally, there is no shortage of researchers who question the existence of any principle of succession in the Ashina Turks, except for their limiting the group of potential successors to the charismatic Ashina clan. The final recipient of the throne was determined by the political and military power of a particular candidate. Cf. Fletcher 1979, 238-239; He Xingliang, Guo Hongzhen 2008, 78-79; Skaff 2012, 78. 
there may have been a place for prominent members of a given genea, i.e., those with greater social capital, to have a voice. The information provided by Constantine VII Porphyrogenitus leaves no doubt that in the mid-1oth century there was a group of families that had reserved for themselves power over individual units of Pecheneg ethnos. The existence of such a quasi aristocracy is also confirmed by later accounts. They must have had more of a voice within individual geneai than average members. However, it is difficult to say whether this advantage assumed an institutionalized form, such as a council comprised of 'more worthy' Pechenegs. If such a council did in fact exist, it probably also included candidates for future chiefs of a given genea, as well as chiefs of smaller units. Such an institution, or perhaps simply an influential pressure group, could realistically co-rule, limiting the role of the current head of a given genea to the role of primus inter pares. ${ }^{87}$

It seems that the existence of both types of collegial institutions is confirmed by written sources. Bruno of Querfurt, who entered the lands of the Pechenegs in the spring of 1008 with the intention of preaching the Gospel, came across some of their 'larger people' (maior populus) and had to wait a week before they could gather to pass judgement on the missionary. ${ }^{88}$ The fact that members of the community, notified by messengers, arrived at the gathering (concilum) in a relatively short period of time, gives rise to the assumption that this was not the whole ethnos of the Pechenegs, but rather one of its larger units. The functioning of a congregation comprised of warriors is confirmed by the account of John Skylitzes. A Pecheneg force (15,0oo riders and four chiefs) sent against the Seljuks by Emperor Constantine IX Monomachos in the spring of 1049 were to hold a meeting near Bithynia, during which a decision was made about whether to begin a rebellion against Byzantium. The

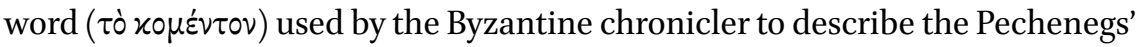
gathering probably did not come from their language, but was a Greek form of the Latin word conventus. ${ }^{89}$ Anna Komnena describes the following incident. During fighting with Byzantium there was a dispute among the Pechenegs over what to do with prisoners-of-war. The chiefs wanted to kill them, but this was opposed by a number of warriors, who hoped to obtain a ransom for them.

87 Moszyński 1996, 53; Pletneva 1958, 192-193; Tryjarski 1975a, 573. The last two researchers believe that before the mechanism of succession among the Pechenegs came to assume an automatic formula, new chiefs may have been elected by the members of a given genea.

88 Bruno, 99. Cf. Pletneva 1958, 192; Tryjarski 1975a, 573. For a dating of Bruno's mission: Paroń 2013, 116 (n. 68).

89 Io.Scyl., 46o; Wortley 2010, 430-431. Cf. Moravcsik 1951, 225-233; Pritsak 1975, 220. 
In the face of the opposition of their subordinates, the commanders abandoned their plans..$^{90}$

The 'public gathering' could have provided an important counter-balance to the opinions of more influential individuals. In St. Bruno's letter we learn that his fate would have been a foregone conclusion if the decision of the more important members of the community (maiores terrae) had not changed the unequivocally hostile position of the people. ${ }^{91}$ It is significant that the missionary does not mention any Pecheneg chiefs, heads or princes. In the light of his account, the steppe people seem to have been guided by a collegial structure in which none of them stood above the others. The lack of clear leadership may have been due to its limited authority, which would confirm the thesis that the heads of the geneai, about whom Constantine vil wrote, as members of the elite were in fact 'first among equals'.

An issue not yet addressed in this study is the question of the existence of central institutions among the Pechenegs, i.e., those that incorporated the ethnos as a whole. This problem is especially important for understanding the ability of steppe people to act together before external political powers. The information contained in De administrando imperio seems to indicate that among the Pechenegs there was a 'hierarchy of tribes', also observed in other nomadic ethne. Its residual form is confirmed by the final passage of Chapter 37:

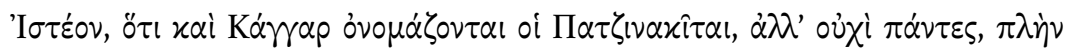

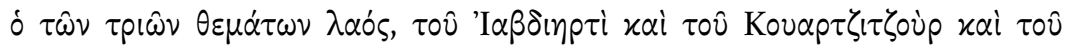

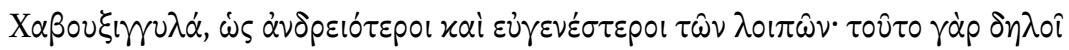

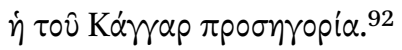

The Pechenegs are also called 'Kangar', though not all of them, but only the folk $[\lambda \alpha \dot{s} \varsigma]$ of the three provinces of Iabdierti and Kouartzitzour and Chabouxingyla, for they are more valiant and noble than the rest: and that is what the title 'Kangar' signifies.

The above description seems to indicate that three geneai of Pechenegs enjoyed greater prestige than the others. On the basis of other information from $D e$ administrando imperio it can be concluded that the Kangar was the oldest part of the Pecheneg political organism, around which the remaining tribes were

\footnotetext{
$90 \quad$ An.Kom., vil 4.4 (p. 216).

91 Bruno, 100.

92 DAI, XXXVII 68-71 (p. 170/171).
} 
united. ${ }^{93}$ Constantine viI clearly states that earlier, i.e., in the times of their first clashes with Magyars, all Pechenegs called themselves Kangar. This kind of story - assuming that it is not just a legend - seems to suggest that the three tribes mentioned could have enjoyed some real, and not just honorary political primacy. However, it is very difficult to determine how this manifested itself. In De administrando imperio we find no additional information, but we do find some in another work attributed to Emperor Constantine viI. In De cerimoniis aulae Byzantinae, a number of political subjects (states and peoples) are mentioned with whom Byzantium maintained diplomatic contacts. The author of the work also described the nature of these relations. Letters ( $\tau \dot{\alpha} \gamma p \alpha \dot{\alpha} \mu \alpha \tau \alpha)$ with a golden seal of the appropriate value were sent to independent rulers,

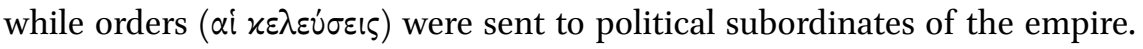
The heads of the Pechenegs (the author uses the plural form) were to receive letters bearing a two-solidi gold seal. ${ }^{94}$ The steppe dwellers were therefore recognized by Constantinople as an independent people, headed by several, probably eight, tribal chiefs. Worthy of note is the Emperor's lack of knowledge about any central institutions of power. The importance of the Pechenegs to Constantine VII's political plans would seem to exclude the possibility of his being ignorant about such a matter. This would mean that there was no unified power leader among the Pechenegs in the mid-1oth century.

There are, however, relations that seem to contradict this last statement. In Chapter 17 of al-Mas'ūdì's Golden Meadows we read that each of the four peoples (including the Pechenegs) who attacked the Byzantine fortress Walandar (W.l.nd.r.) had a king. What is more, before the battle the ruler of the Pechenegs requested he be given supreme command and was granted it. ${ }^{95}$ Moreover, the anonymous Persian geography The Regions of the World (Hudüd al-'Ālam) reads:

The [Pechenegs] have no towns; their chief (mihtar) is one of themselves. ${ }^{96}$

Finally, we learn from John Skylitzes, in his account of the conflict between Kegenes and Tyrach, that the latter came from a noble family and was the

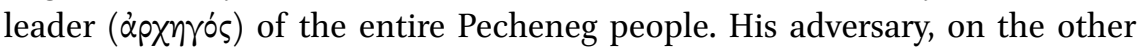

93 DAI, XXXVII 68-71; XXXVIII 19-21, 24-26 (p. 170/171).

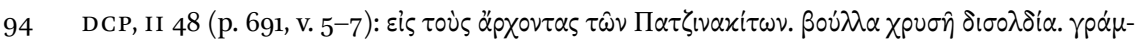

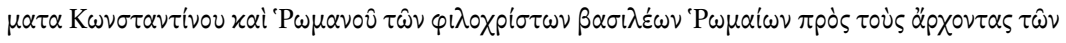

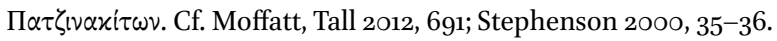

95 al-Mas'ūdī, Les Prairies, II, 58, 62; Pellat 1962, 177, 178.

96 Hudūd al-'Ālam: Minorsky 1937, 101; Göckenjan, Zimonyi 2001, 208. 
hand, was said to come from the lower classes. ${ }^{97}$ The chronicler clearly states that in the mid-11th century there was at least an ad-hoc form of unified leadership over the whole ethnos.

Is it possible to reconcile these quite unambiguous sounding accounts with the silence of Constantine VII? Perhaps a partial explanation is provided by the space in time that separates the individual accounts, or more precisely De administrando imperio and Skylitzes' chronicle. We have already stated that the more than 100 years that elapsed between the writing of both works was sufficient time to bring about changes in the Pechenegs' political system. However, there are two more accounts, both of which are much closer, almost contemporary, to De administrando imperio. The first is Mas'ūdi's work, which dates back to the 940s. ${ }^{98}$ In his description of events that took place around the year 934, Mas'ūdì mentions the 'king of the Pechenegs'. ${ }^{99}$ The second work, The Regions of the World, was written in the early 98os. However, it is more difficult to determine to which period in the Pechenegs' history to date the facts presented in the Persian geography. If we consider it part of the Jayhānī tradition, we would date this reference work to the gth century, which is what Vladimir Minorsky has done. ${ }^{100}$ The relevant passage, however, does not find a counterpart in other sources, drawing on a lost work written by a Samanid dignitary, which suggests that the account refers to a later period in the history of the Pechenegs. Such an interpretation is more probable due to the fact that a unified leadership is attributed to the so-called Turkish Pechenegs. The anonymous geographer could have understood by this name some part of the ethnos which at the end of the gth century had not left the Caspian steppe and was thus cut off from the main mass of the people and most probably subordinated to the Uzes. ${ }^{101}$ The mihtar mentioned by the author of Hudüd al-'Álam would therefore have been the leader of a small group that remained outside the Pechenegs' sociopolitical organization.

It is more difficult to reconcile the data from Golden Meadows with the information provided by Constantine viI Porphyrogenitus. It is possible to resolve this discrepancy between sources in part by taking into account the circumstances in which the 'king' mentioned by Masudi appears. He stood at the head of a war expedition, which leads us to accept the hypothesis that in the event of the need for a joint armed action, power over the entire Pecheneg ethnos

97 Io.Scyl., 455 (v. 39-43); Wortley 2010, 427.

98 Swoboda 199oa, 228; Lewicka-Rajewska 2004, 45.

99 Marquart 1903, 64. Cf. also Chapter 5 of the present book.

100 Minorsky 1937, 314. Similarly Zimonyi, Göckenjan 2010, 208 (n. 144).

101 DAI, XXXVII 50-57 (pp. 168-169). Ahmad ibn Fadlan mentions the existence of such a group, which possibly lived near Shalkar Lake. Cf. footnote 53 in the previous chapter. 
could be granted to one of its prominent members for a strictly defined period of time, with the consent of all the tribes. This unified command gave them a better chance of conducting their military operation efficiently, but once the fighting was over, the power of the chief commander expired. Constantine VII Porphyrogenitus does not mention this because the description of sociopolitical relations contained in the Chapter 37 of his work concerned a period of peace.

In the mid-1oth century there were thus three tribes (geneai) among the Pechenegs which enjoyed considerable prestige, and which could have led to their effective possession of political primacy. If Pletneva's hypothesis is true, and the Kangar brought the other five clans together by means of conquest, ${ }^{102}$ then the credibility of the previous hypothesis increases significantly. Unfortunately, written sources do not provide us with such certainty. There are a number of doubts about the emergence of a unified political authority among the Pechenegs. However, we can assume that one did not exist when they arrived to the Black Sea steppe. When there was a need for joint military action, the chief command was probably entrusted to one of the chiefs. Given the fact that the Kangar tribes maintained their political domination, we can assume that the chief commander might have come from among them. His power was limited in that it concerned only military matters and expired at the end of combat. During times of peace, the leadership of the

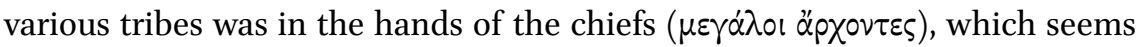
to be confirmed by information found in De cerimoniis aulae Byzantinae. The upsetting of the sociopolitical organization of the Pechenegs at the turn of the 1oth and 11th centuries and the constant threat posed by the Uzes, which required the engagement of the entire ethnos, could have opened up a path to the establishment of a monarchy. This seems to be indicated by the case of Tyrach, who gained power over all of ethnos before the mid-11th century. The metamorphosis of this political system probably took place shortly before Skylitzes' account was written. This seems to be evidenced by the clear limitations placed on Tyrach's power in favour of the lesser chiefs around him. It is possible that he held the position among them of primus inter pares. ${ }^{103}$ We do not know into what spheres his authority extended. One can assume that they were probably military in nature, considering that his power most

102 Pletneva 1958, 162-163.

103 Skylitzes writes that after the formal recognition of the sovereignty of Constantine IX Monomachos, Tyrach and his 140 chiefs were brought to Constantinople. The fact that the whole group was baptized and received with the greatest honours additionally proves its members' aristocratic origin. This seems to prove the persistence of social structures and institutions limiting Tyrach's powers. Io.Scyl., 459 (v. 83-85); Wortley 2010, 43 O. 
likely grew out of his temporarily being entrusted with the function of chief commander. He probably also had to represent his entire people in talks with external political partners. This is evidenced by the fact that Tyrach sent a message to Constantinople with a demand to limit Kegenes' attacks on his former compatriots. ${ }^{104}$ However, it should be stressed once again that his position was not so strong that he was able to take decisions independently in regard to his policies, be they external or internal.

There remains the question of how to name the formula for political life adopted by the Pechenegs. This requires the use of terminology that poses a number of problems, including those outlined above. Nevertheless, it is impossible to avoid defining the shape of the Pechenegs' system of political organization because it largely determined the shape of their relations with the outside world. The aim of the following discussion will therefore be to determine whether they developed a model of political organization that allowed them to effectively defend their interests in their contacts with neighbouring political powers. This question is closely related to that of the origins of the state among steppe peoples. In the case of nomadic societies, a number of factors favouring its creation have already been pointed out. Academics basing their investigations on a Marxist paradigm have focused mainly on internal changes affecting the social and economic sphere. Inequalities in terms of wealth, as in the case of other societies, led to the emergence of a class society, which the state had to choose as the framework for its existence. ${ }^{105} \mathrm{~A}$ scheme of this kind cannot be maintained in pure form. This seems to have been proven by findings which show that permanent social divisions are often secondary to the creation of the state. ${ }^{106}$ Moreover, the schematism of orthodox Marxist approaches, which fail to take into account the specificity of steppe communities, is striking. Today a direction in academic reflection seems to dominate whose most eminent representatives are inclined to seek the main impulse for state formation outside the nomadic communities themselves. Contacts with the outside world created the conditions and the need for the creation of a state. ${ }^{107}$ It was not just external threats or the expansion of neighbour-

\footnotetext{
104 Io.Scyl., 457 (v. 20-27); Wortley 2010, 428.

105 Vladimirtsov 1934; Grekov, Iakubovskii 1950; Pletneva 1967; 1982; Fedorov-Davydov 1973; Kyčanov 2010. A different position is taken by G.E. Markov (1976, 312-313), who both effectively criticizes the scheme of orthodox Marxist approaches, and considers that steppe people were unable to create a state, because they were unable to create a permanently hierarchical society. Cf. also N.N. Kradin's remarks: 2003, 169-170, 172.

106 Tymowski 1992, 270; Khazanov 1984, 177-178.

107 There is an entire group of researchers inspired mainly by the studies of the American orientalist Owen Lattimore. (1988 [first published in 1940]). Khazanov 1984, 228-233; Barfield 1992; 1993; Di Cosmo 1999; 6-9; Kradin 2003, 171-172.
} 
ing steppe people that created the necessity to place power into the hands of a single person or small group of individuals. Problems of this kind did not have to lead to the emergence of a permanent centre of power. There have been many cases when after an external threat was neutralized or an armed conflict ended, the system of social relations returned to its initial state. ${ }^{108}$ Some researchers attach much greater importance to the regular contacts nomads had with settled communities. These relations led steppe people to assimilate their models of political organization; moreover, whether through conquest or payment of tribute, they could obtain the means to maintain state structures. ${ }^{109}$ The majority of organisms of this type were, as mentioned above, highly unstable in character. However, this does not change the fact that they were the best tools for nomads to define their relations with the outside world under the most favourable conditions possible for them.

The political organization of the Pechenegs has been described in a number of very different ways. Eugeniusz Kucharski and Marian Lewicki believe that the Pechenegs 'created [....] a perfectly organized and threatening steppe state'. According to these authors, this state was union (Pol. rzesza) in character, i.e., a militarily organized state consisting of various ethnic elements of both Turkic and non-Turkic origin. ${ }^{110}$ This last claim is confirmed by archaeological data. ${ }^{111}$ Nevertheless, it is difficult to draw upon the findings of these Polish researchers for support, as they were presented without any arguments to support them. The existence of a more developed form of political existence, perhaps a state, seems to be acceptable to Josef Németh in the case of the Pechenegs. A Hungarian scholar, made a linguistic analysis of the eight names of tribes mentioned by Constantine Porphyrogenitus. His results, accepted by the majority of researchers, boil down to his finding that each of the tribe names contains two elements: an equine coat colour term and a honorific title. According to the Németh, these titles and offices were inherited by the leaders of particular tribes, while their names originally designated administrative units. ${ }^{12}$ Despite its unquestionable scientific value, it is very difficult to interpret the results of the linguistic analysis presented above. It is not exactly clear to what period in

108 However, a long-term external threat may force political centralization, which, if maintained over a long period of time, will lead to lasting changes of a state-forming nature. Cf. Di Cosmo 1999, 9-18; 2002, 178-19o; Steuer 2006, 227-236 (based on other source material, he points to the mechanism of militarization, which can lead to the creation of new tribal or state structures).

109 Khazanov 1984, 230-233.

110 Kucharski, Lewicki, 1934, 44.

111 Pletneva 1958, 162.

112 Németh 1922, 219-225; 1930, 27-32. Cf. Marquart 1929, 84-85; Menges 1944-45, 26o-269; Vörös 2002, 623-627. 
the history of the Pechenegs it should be applied, the mid-1oth century, which seems doubtful, or an earlier period. It is also puzzling that none of the above tribe names is found in the later history of the Pechenegs. According to Pritsak, the political structure of Pechenegs can be described as a double kingdom. ${ }^{113}$ As in many other nomadic groups in the Middle Ages, power was allegedly held by two khagans. ${ }^{114}$ The existence of such an institution is confirmed by a very late mention contained in the works of two Arab geographers: Ibn Sa'id al-Maghribi (13th century) and Abu al-Fida (14th century). ${ }^{115}$ However, the statements of both authors arouse suspicion, ${ }^{116}$ especially if we compare them with the information of a writer from the 1oth century, i.e., a contemporary of the Pechenegs: Constantine Porphyrogenitus.

Edward Tryjarski has expressed scepticism about claims the Pechenegs created their own state. Tryjarski draws attention to a lack of 'tribal solidarity' among the Pechenegs, expressed through frequent fratricidal conflicts and a tendency to enter into the service of foreign rulers. He also seems correct in his observation that the Pechenegs lacked a strong leader who could have consolidated power over the entire ethnos and directed its future path. Both of these factors led to political weakness in the Pechenegs and to their ultimate defeat. ${ }^{117}$ Pletneva also assessed the coherence of the Pechenegs' political organism very negatively. She stated that the four western and four eastern geneai mentioned by Constantine viI were not one, but two completely independent tribal unions. Unfortunately, she does not provide any justification for her hypothesis. ${ }^{118}$ Victor Spinei has recently expressed a very similar view. He particularly emphasized the lack of intercommunity cohesion among Pechenegs. ${ }^{119}$

\footnotetext{
113 Pritsak 1975, 221.

114 The existence of a double khaganate has allegedly been confirmed for the Blue Turks, Avars, Khazars and Hungarians: Pritsak 1988, 754; Györffy 1994, 87-104. The problem is that in most of these cases (especially the Avars and Khazars) we are dealing not so much with a double khaganate, as with an evolution of the political system which led to reducing the real power of monarchs and limiting their role to the sacral and symbolic spheres. Political affairs began to be conducted on behalf of the ruler by a high-ranking dignitary. Similar mechanisms seem to have existed in all civilizations (cf. Merovingian kingdoms, Abbasid Caliphate) and can hardly be seen as evidence of a double monarchical system. Cf. also Pohl 1988, 293-300; Avenarius 1988, 147-150.

115 Ibn Sa'id al-Magribi: Konovalova 2009, 34; Abu-l-Fida, II, 293; Konovalova 2009, 118.

116 P.B. Golden considers the above information to represent a topos: 199o, 273; 1992, 267. Cf. Konovalova 2009, 73 (n. 3).

117 Tryjarski 1975a, 568-569.

118 Pletneva 1958, 192.

119 Spinei 2003, 106-107.
} 
While acknowledging the arguments of these three researchers on many issues, it should be noted that they underestimated the 'tribal solidarity' of the Pechenegs. This problem will be discussed in more detail in the fourth part of this chapter. ${ }^{120}$ The transition to acting in the service of foreign countries intensified markedly in the late period of the Pechenegs' history, after their political significance had significantly decreased. ${ }^{121}$ Moreover, this usually concerned small groups or even individuals, so it is difficult to consider it a measure of the degree of coherence in the Pechenegs' internal ethnos throughout their history. In terms of internal contradictions, it is difficult to deny that they existed among the Pechenegs. The conflict between Kegenes and Tyrach is the best testimony to their existence. ${ }^{122}$ However, they were ambivalent in character. On the one hand, they splintered the unity of ethnos; on the other, in the case of Kegenes and his victory, they could have led to the emergence of a strong centralized authority among the Pechenegs. ${ }^{123}$ Moreover, it is worth noting that internal struggles were an extremely frequent phenomenon and affected communities that had already managed to create their own states. The history of the Ashina Turks or Chingisids best illustrates this statement. It is therefore not so much a problem of determining whether armed conflicts took place within a given nomadic community, but rather of examining whether this led to the creation of mechanisms or institutions that would limit factors conducive to the outbreak of fighting. The Pechenegs seem to have had two institutions that fulfilled such tasks. The first was a territorial division corresponding to the division of the ethnos into tribes (geneai) and 'clans'. The second was the system of succession within tribes, which was most likely conceived of as a limiting factor in power struggles the ruling family. We have already mentioned that the tribe was a less coherent unit within nomadic social organizations, and therefore probably did not stand up well to internal shocks, and thus, preventing them through the creation of a system of inheritance was a necessity that benefited the Pechenegs. However, we should share the doubts of Tryjarski and Pletneva on the question of the existence of a unified political authority who had power over the whole ethnos. As we have noted, even if one came into being, it was in an embryonic form and came in the last years of the independent existence of this ethnos.

120 Cf. excellent information from Constantine viI Porphyrogenitus: DAI, XXXVII 50-57 (p. 168/169).

121 All the examples cited by V. Spinei come from this period.

122 Io.Scyl., 455-457; Wortley 2010, 426-428.

123 Cf. Chapters 4.4 and 7 of the present book. 
Anatoly M. Khazanov also spoke briefly about the political organization of the Pechenegs. In his inquiries, Khazanov relied solely only on the data of Constantine VII. On this basis, he decided that they formed a segmentary structure consisting of eight chiefdoms. ${ }^{124}$ This interpretation, as can be deduced from the terms used by Khazanov, assumes the equal status of individual units (chiefdoms), who could act together against a common enemy; at the same time, they balanced their influence, preventing one of them from gaining dominance. One of the most recent attempts to define the political organization of the Pechenegs was made by Aleksei V. Marey. ${ }^{125} \mathrm{He}$ stated that it possessed all the features of a so-called nomadic empire, but he ultimately considers it to be a complex chiefdom, which could have become a chiefdom proper if a charismatic leader appeared. In addition to their insufficient grounding in source materials, Marey's observations raise doubts because the political organization of the Pechenegs seems not to have met one fundamental condition that would allow it to be considered a nomadic empire. This is the lack of a strong political centre. Marey also does not define the terms used in his analysis. We can only assume that a complex chiefdom can be distinguished from an ordinary chiefdom by the lack of a unified power structure. If so, then Marey's reconstructed model of the Pechenegs' political structure would be identical to the segmentary model.

Therefore, how can we characterize the form of political life that existed among the Pechenegs? Lev Gumilev believed that steppe people adopted two models for the organization of their societies: that of a state $(e l)$ and of a confederation of tribes. The latter is characterized by a lack of central power; its place is occupied by a single tribe, which enjoys a certain honorary primacy, but does not rule. Each tribe is headed by a chief with a considerable level of autonomy. Members of similar federations were united by a mutual desire to defend their independence and therefore banded together only when it was threatened. ${ }^{126}$ The description of the system offered by Gumilev is extremely general, merely a rough sketch; nevertheless, in spite of such reservations, it possesses a certain analytical value. As mentioned above, the Eurasian steppe peoples were able to create political organisms such as early states, which rarely took the form of mature states. The term 'confederation of tribes' raises legitimate objections, as it suggests a voluntary association of the constituent units. Meanwhile, the

\footnotetext{
124 Khazanov 1984, 178-179.

125 Marey 2011, 450-456.

126 Gumilev 1993, 13; 1997, 78. The scholar attributes the confederation model to the T'ie-lê (4th-5th century AD) and the Uyghurs (7th-8th century AD). Both examples, especially the latter, are very controversial.
} 
use of force in the process of creating such political structures was at least as frequent as peaceful means. ${ }^{127}$ Nevertheless, the similarity between the political organism of the Pechenegs and the confederation model seems quite obvious. This is due in particular to the lack of a clearly defined centre of power, or rather, the existence of one that was merely ad-hoc and temporary in nature. The main units of this political organism were chiefdoms, despite the domination of the Kangar, who together formed a segmentary structure. ${ }^{128}$ In spite of the Pechenegs' turbulent history, it was apparently never violated. We can only observe quantitative changes, e.g., the number of main units comprising the ethnos. Its segmental power structure was also in line with the relative egalitarianism of the Pechenegs. There were undoubtedly more influential and richer groups with a quasi-aristocratic status among them, but they never became completely independent of the will of the majority, the role of which, even during military campaigns, cannot be underestimated. ${ }^{129}$ The egalitarianism of the Pechenegs also seems to be emphasized by material traces of funeral rituals, which do not confirm a strong tendency to manifest prestige among the richer or more influential members of the ethnos.

The persistence of such a segmental structure also shaped the relations of the Pechenegs with the outside world. The lack of a strong ruler able to define the interests of the entire ethnos and implement them in their external relations led the Pechenegs to conduct such affairs in a rather instinctive manner, limiting themselves for the most part to reacting to direct threats. Given this situation, one cannot even really speak about their having a defined political strategy, as their actions were based more on political reflexes. In theory, these circumstances should have been favourable to their better organized neighbouring political entities, in particular Byzantium and Rus', whose diplomats could more easily induce the steppe people to pursue interests that benefited these states. However, such a conclusion seems premature. The fact that relations with a divided political organism lacking a distinct political centre were not at all easy requires we exercise caution. On the other hand, the segmented

127 Khazanov 1984, 152.

128 The organization of the Pechenegs is quite reminiscent of the segmental union of chieftains, for which Aidan Southal proposed the term 'segmentary state'. A structure of this type had already developed the three levels of governance typical of a state, though the highest of the three exists only on occasion. Such a state of affairs, however, does not allow for full centralization of power and its independence from lower levels of management, which seems to make it difficult to call this type of political organization a state. Southal 1988, 52-82. Cf. Tymowski 2012, 774-775.

129 Pletneva $(1958,193)$ calls the social and political system of the Pechenegs a military democracy. A similar term is also used by Pritsak $(1975,220)$, who notes that he does not use it in the Marxist sense. 
nature of the Pechenegs' system resulted in an almost complete lack of desire for political expansion aimed at subjugating any of the neighbouring peoples or states. Having conquered huge stretches of the steppe from the Danube to the Don at the end of the gth century, the Pechenegs never tried to enlarge their territory further. Perhaps their further expansion was limited by geographical factors (the Carpathian arch in the west, the Black Sea in the south), but they never tried to expand their borders at the expense of the Khazar Khaganate or Rus'. Such projects in the early 1oth century, after all, might have brought positive results. Similarly, after crossing the borders of Byzantium in the mid11th century, the Pechenegs guarded their separateness, but did not attempt, like the Bulgars, to create a strong state organism. Even clearer conclusions can be drawn from a comparison with the Huns, the Ashina Turks and the Mongols, whose history at certain times is one of constant and unrestrained conquest. Such a comparison best demonstrates the differences resulting from the fact that these other ethne created strong states based on a highly efficient military organization. Meanwhile, the aggression of the Pechenegs very often arose from non-political motives, which we will attempt to show in subsequent chapters of this work.

\subsection{Economy}

The economy of nomadic peoples is based on extensive pastoralism, usually in the form of open-range or free grazing, in which herds remain in open spaces year round, rather than being driven into enclosures, with the animals moving from place to place within a specific territory. They are accompanied by a large majority of the population, for which pastoral activity is their source of livelihood. Animal production is generally geared towards meeting the basic needs of the community rather than profit, which is fundamentally different from modern animal husbandry in a market economy. This does not mean, of course, that a population engaged in extensive pastoralism did not obtain surpluses that could become an item of trade. Experts in the subject distinguish several types of pastoralism, two of which can be attributed to nomadic peoples: nomadism proper and semi-nomadic pastoralism. These differ in terms of whether or not agriculture functions as a complementary form of economic activity. In the first, less common case, agriculture is not practiced at all. ${ }^{130}$

The Pechenegs most likely practiced semi-nomadic pastoralism. The areas in which they lived, as we could see in Chapter 1, were definitely conducive to

130 Khazanov 1984, 15-22. 
this form of economic activity. This particularly concerns the Black Sea steppe, whose vast stretches of land were covered with tall grasses, perfectly suited for animal feed. ${ }^{131}$ The only significant impediment posed by the steppe was its harsh winters, which covered the steppe floor with a thick layer of snow, from which sparse clumps of grass protruded. However, the conditions during winter did not always pose a significant threat to livestock, which were able to extract food from under the snow. A real threat, however, was posed by glazed frost, which often appeared at the turn of late winter and early spring, when ice covering the snow prevented the animals from getting food, which in turn led to significant losses in the herd. This danger could only be avoided by moving to a less snowy area or one free of ice cover. ${ }^{132}$ In summer, droughts on the steppe were a major problem, but during this time animals were driven to the forest-steppe zone, where conditions were more tolerable.

Most scholars say that in a developed nomadic economy, herds generally consist of horses, sheep, goats, large horned cattle, and camels. ${ }^{133}$ Specialization in the breeding of one species is an extremely rare phenomenon. A specific feature of the Eurasian steppe is the existence of herds comprised of different animals, ${ }^{134}$ with sheep and horses dominating. ${ }^{135}$ The raising of horses was a characteristic feature of the Eurasian steppe, where these animals served not only as a means of transport, but also as a source of milk and meat. The importance of sheep to the nomadic economy is most clearly demonstrated by an Uzbek saying that these animals came to earth straight from heaven. ${ }^{136}$ Both sheep and horses were perfectly adapted to live in the difficult conditions of the steppe. They were able to feed themselves even in the most difficult circumstances. According to modern-day scholars, a steppe horse is able to dig up grass from underneath snow cover up to a depth of $40 \mathrm{~cm}$, and in extreme cases, even $50 \mathrm{~cm}$, while a sheep can find grass in up to $15 \mathrm{~cm}$, or even $17 \mathrm{~cm}$, of snow. ${ }^{137}$ Herodotus, Pseudo-Hippocrates, and Strabo all wrote about this. Recent data seems to confirm the information provided by Ahmad ibn Fadlan, who wrote: 'The sheep graze mostly on what lies underneath the snow, digging

\footnotetext{
131 Pletneva 1958, 186.

132 Pletneva 1958, 187. Cf. Gumilow 1997, 12-13; Kałużyński 1970, 3 o.

133 Moszyński 1996, 18; Pletneva 1958, 187; Jagchid, Hayer 1983, 22; Kałużyński 1983, 59.

134 Khazanov 1984, 46.

135 Khazanov 1984, 46-47.

136 Khazanov 1984, 46.

137 Khazanov 1984, 46, 5o. Sechin Jagchid and Peter Hayer $(1983,21-22)$ are of a slightly different opinion as far as the sheep's abilities is concerned. According to both researchers, these animals, like cows, require feeding by humans during winter; otherwise they are likely to starve to death.
} 
for the grass with their hooves.' He then adds: 'If they do not find grass, they eat snow instead and grow inordinately fat.' 138

Less frequently among the herds of animals bred by nomads were large horned cattle. Although steppe peoples appreciated their qualities, the high feed requirements and the fact that they did not tolerate a nomadic lifestyle well meant that they constituted a small percentage of the nomads' livestock. Experts on the subject claim that an increase in the number of large cattle indicated that the nomadic community raising them was undergoing a process of sedentarization. Yet we have confirmation of the presence of these livestock animals on the Black Sea steppe already in antiquity from the writings of Herodotus, Pseudo-Hippocrates, Strabo, and elsewhere. ${ }^{139}$

In Eurasian areas, goats usually grazed in desert or semi-desert areas. They were not very highly valued, and were most commonly reared by poorer people. ${ }^{140}$ The question of the presence of camels on the steppe is somewhat more complicated. The natural conditions there, especially during the harsh winters, made it very difficult for camels to survive. Among the early Eurasian nomads, camels were rather rare. It is usually assumed that an increasing prevalence of this animal most likely occurred during the Mongolian period. ${ }^{141}$ However, data from chronicles seems to contradict this. In accounts about Russian expeditions against the Cumans, we find information that camels belonging to the steppe-dwellers were taken as booty by the princes. ${ }^{142}$

In the case of the Pechenegs, the accounts of Constantine Porphyrogenitus and Muslim writers testify to the breeding of horses, horned cattle, and sheep. ${ }^{143}$ We can suppose that the population of these animals was quite numerous because they were objects of trade. ${ }^{144}$ The lack of source data leads us to assume that the Pechenegs bred goats but on a small scale or not at all. The possible presence of camels in their herds is also questionable. Pletneva states, however, that their presence on the Black Sea steppe is confirmed by a fresco uncovered in Saint Sophia's Cathedral in Kiev. It depicts a bactrian camel, a species which was bred in Inner Asia. According to Pletneva, the inspiration

138 ibn Fadlan: ibn Fadlan, 212-215; Zeki Validi Togan 1939, 33; Kovalevskii 1956, 13o; Frye 2005, 42.

139 Cf. Chapter 1 of the present book.

140 Jagchid, Hayer 1983, 22; Khazanov 1984, 47.

141 Spuler 1967, 253, 361, 373, 410, 423; Khazanov 1984, 48.

142 PVL 1, AM 66o3 (1095), col. 228; AM 6611 (1103), col. 279; PNL, AM 666o (1152), p. 196. Cf. Noonan 1992, 311 .

143 DAI II 6-8, (p. 5o/51). Gardīzī: Martinez 1982, 152; Göckenjan, Zimonyi 2010, 165; Bakrī: Kunik, Rozen 1878, 59; Göckenjan, Zimonyi 2010, 222; Marwazĩ: Minorsky 1942, 32-33; Göckenjan, Zimonyi 2010, 25o. Zakhoder 1967, 74.

144 DAI, II 6-8, (p. 50/51). 
for the artist's image came from the southern neighbours of the Rus'. Was this the Pechenegs? ${ }^{145}$ The only mention in written sources about their possible use of camels comes from The Life of Lietbertus, Bishop of Cambrai. ${ }^{146}$ On his way to the Holy Land in ca. 1054 he travelled through the Balkans, where he and his companions were attacked by 'Scythian robbers (latrunculi Sciticae gentis)', who are said to have ridden horses and camels (sessores equorum camelorumque). ${ }^{147}$ The characteristics of the attackers supplied by the author leaves no doubt that they were nomads, which has prompted researchers to identify these 'Scythian robbers' as Pechenegs. ${ }^{148}$ This hagiographical source would therefore contain testimony of camel breeding by these nomads. The credibility of this account, however, is limited. It is worth noting that The Life of Lietbertus was written ca. 1099-1100, i.e., almost half a century after the saint's pilgrimage. Its author, Raoul (Rodulphus), a monk of the Abbey of the Holy Sepulchre of Cambrai, may have accompanied Lietbertus on his journey, but his message is quite jumbled and plagued with numerous errors. ${ }^{149}$ The characteristics of the attackers, in particular, arouses the researcher's doubts. Raoul initially describes them as coming from a Scythian tribe, then assigns to them the practice of circumcision, found among the Saracens, and finally, several lines below, simply refers to them as Saracens. Similar reasoning gives rise to suspicions that in his description of the nomadic bandits, the monk simply combined the characteristics of several nomadic peoples with whom he came into contact during his pilgrimage to the Middle East. This suspicion is further substantiated by the fact that the nomads of the Great Steppe rarely used camels as mounts, while in the biographer's account, they are mentioned alongside horses. We therefore cannot use The Life of Lietbertus as a basis for concluding that the Pechenegs bred camels.

The same applies to archaeological sources. The remains of camel bones have been discovered at sites located within or nearby territories that could have been controlled by the Pechenegs. A number of such finds come from cemeteries and settlements located on the Don, the upper Severskii Donets, the middle Oskol and in Dinogetia (near today's village of Garvăn) on the lower Danube. ${ }^{150}$ These discoveries have been interpreted as evidence of

\footnotetext{
145 Pletneva $1958,187-188$.

146 V.Liet., 838-866.

147 V.Liet., XXXIII-XXXIV (pp. 854-855).

148 Uzelac 2010, 65-67.

149 The author has very little knowledge of the geography of south-eastern Europe and the Middle East: he confuses Corinth with Thessaloniki and places Isauria in the Balkans, somewhere between Dalmatia and Corinth. V.Liet., Xxxv (p. 855).

150 Kovalev 2005, 81, 86 (map no. 2), 88-89, 99; Haimovici 1984, 311-319.
} 
the functioning of trade routes; meanwhile, the Pechenegs were involved in trade, especially in the first two-thirds of the 1oth century. Long-distance trade required the replacement of animals during the journey. This mechanism is described by Ahmad ibn Fadlan. ${ }^{151}$ The Pechenegs, who were involved in this trade, could therefore have provided merchants travelling across their lands with necessary means of transport, including camels. Yet, the data from written sources is insufficient to dispel any doubts. Al-Gardīzī states that while travelling through the lands of the Pechenegs it was necessary to purchase riding animals, but he only mentions horses. ${ }^{152}$

We can say a bit more about the types of horses used thanks to archaeological evidence. Data from the vicinity of the Sarkel confirms the presence of two breeds of horses among the steppe peoples. The first of these, with a large head and strong, massive limbs, was typical of steppe horses. The second one was characterized by a much smaller head, narrow nostrils and long, thin legs. This breed occurred much less frequently on the steppe and was probably used as a mount by the nomadic aristocracy. ${ }^{153}$

The nomads' horned cattle were said to be extremely hardy and able to survive even in the harshest conditions, although they were not a particularly productive species. ${ }^{154}$ However, in light of the above considerations, it must be concluded that they were probably not very numerous and therefore could not have been traded on the same scale as the horses and sheep, two other animal species mentioned by Constantine VII. There is no doubt, however, that the Pechenegs were engaged in the breeding of large horned cattle.

As a basic branch of the nomad economy, pastoralism provided access to a number of essential products. Above all, it provided food. These animals were bred for meat, among other things, so the nomadic menu included sheep and beef, as well as goat and horse meat. ${ }^{155}$ The latter, as a high-calorie food, ${ }^{156}$ had a particularly high nutritional value, and also contained minerals, vitamins A and B, and amino acids. ${ }^{157}$ Animals were usually slaughtered in autumn, when

\footnotetext{
151 See the discussion on trade below.

152 Gardīzī: Göckenjan, Zimonyi 2010, 166; Zakhoder 1967, 75. A.P. Martinez explains the relevant passage in a slightly different way $(1982,152)$.

153 Pletneva 1958, 188.

154 Pletneva 1958, 187.

155 Pletneva 1958, 187; Kałużyński 1983, 61, 65; Khazanov 1984, 52-53.

${ }_{15} 6$ Horsemeat contains the most calories (4090 calories per $\mathrm{kg}$ ) of all types of meat consumed by the steppe people. Meanwhile, mutton and beef have 4043 and 2365 calories, respectively. Smith 2000, 2 (the data cited by the researcher was converted from pounds into kilograms).

157 The fact that the Pechenegs consumed this type of meat is well documented. Cf. Mich. Psell., VII 68 (p. 241); Sewter 1953, 242. Ott.Fr., VI 10 (pp. 271-272).
} 
livestock, thanks to the abundance of food in summer, had gained weight. 158 The nomads' livestock above also supplied milk, which was consumed in various forms; ${ }^{159}$ however, milk production was not constant all year round. Having been exhausted by the severe conditions during winter, the animals in late winter and early spring produced almost no milk. ${ }^{160}$ Therefore, while in winter the nomads' diet was based on meat, in summer, dairy products were most commonly consumed. In the case of the Pechenegs, we have been able to confirm the use of blood from livestock as food. ${ }^{161}$ However, its use for this purpose was probably relatively rare. This seems to be proven by analogous data from other steppe peoples. It cannot be excluded that blood was consumed in extreme situations, e.g., during an exhausting march, as is clearly indicated in Marco Polo's account. ${ }^{162}$ Blood was also obtained during the slaughter of animals, when, as the example of the Mongols shows, it was stored and added to broths and sausages. ${ }^{163}$ Although consumed in a smaller quantities than milk, some basic plant products, i.e., vegetables and certain types of cereals, were also a part of the diet of each nomad. ${ }^{164}$ Animal skins provided material for clothing, while sheep wool was used to make felt that was used to cover yurts. ${ }^{165}$

Extensive pastoralism involved the need for frequent migration and changes in encampment sites. The migrations of Eurasian steppe peoples, who mainly inhabited areas within the temperate zone, occurred quite regularly, based on seasonal changes. Their routes were generally linear and longitudinal, i.e., they usually ran along the north-south axis. They usually travelled north in summer. Here they found better pastures on which, despite the warm season, vegetation continued to grow. In winter, the animals grazed in the south, where

\footnotetext{
$15^{8}$ Kałużyński 1983, 66; Allsen 2001, 128.

159 Kałużyński 1983, 69; Moszyński 1996, 43-45; Tryjarski 1975, 201; Allsen 20o1, 128.

16o Moszyński 1996, 46; Kałużyński 1983, 68.

161 Mich.Psell., VII 68 (p. 241); Sewter 1953, 242. Cf. Paroń 2011, 129-13o.

162 Mar.Polo, I 54.

163 Allsen 2001, 128.

164 Contrary to the common stereotype, plants sometimes comprised a larger proportion of the nomadic diet than meat. According to research by Sergei Vainshtein, the Tuva inhabitants, like the Khalkha Mongols in the late 19th and early 2oth centuries, obtained 55.31\% of their calorie intake from the consumption of milk and milk products, $24.38 \%$ from the consumption of plant products (sic!) and 20.31\% from eating meat. Vainshtein 1991, 122; Maiskii, 1921, 156. However, it is worth noting here studies according to which steppe people consumed only small amounts of cereal products. There merely provided a supplement (albiet an essential one) to their diet. Shakhanova 1989, 114. Of more in general on nomadic diet: Khazanov 1984, 52.

165 Pletneva 1958, 189-19o; Kałużyński 1983, 61.
} 
it was warmer, thanks to which they were able to extract food from under a thinner layer of snow. In general, we can say that the main factor that determined the route of migration in summer was access to water, and in winter, access to fodder. A similar form of migration was practiced by the Black Sea steppe-dwellers. ${ }^{166}$ Giovanni da Pian del Carpine noted that nomads stayed in the Black Sea region throughout the winter. Similar observations can also be found in Herodotus, Strabo and other authors. ${ }^{167}$ Regular invasions of Rus' in the summer by the Cumans also proves that at that time of the year these steppe-dwellers were in the forest-steppe, not far from the borders Kievan Rus. ${ }^{\prime 68}$ In winter, however, the Byzantine Empire's possessions were probably at greater risk. It would seem that the characteristics of the migrations presented here could also be applied to the Pechenegs.

The portage of one's belongings during migratory journeys required adequate means of transport; this was supplied by the nomads' herds. It is possible that steers were harnessed to the carts, although in illustrations in the Radziwitt Chronicle we can also clearly see horses serving as draught animals. ${ }^{169}$ The Mongols also used camels for such purposes, ${ }^{170}$ though such practices in the case of the Pechenegs have not been confirmed. During wars and plundering expeditions, mounted units naturally rode horses.

The dominance of extensive pastoralism in the economy of the steppe did not exclude the existence of other ways of making a livelihood. Shortages in foodstuffs were compensated for by hunting, the development of which, as we have already seen, was favoured by the rich fauna of the Black Sea steppe. ${ }^{171}$ Hunting activities could either be limited in scale, involving a small number of people, or take the form of relatively large, well-organized expeditions in which the whole tribe or clan participated. The Mongols are known to have organized hunting expeditions with such great fanfare that they resembled in some ways military excursions. ${ }^{172}$ Some researchers are even inclined to suppose that these events played the role of military exercises, the aim of which was to educate participants in skills useful on the battlefield. ${ }^{173}$ It is difficult

\footnotetext{
166 Khazanov $1984,5^{0-52 .}$

167 Cf. Chapter 1 of the present book.

168 Golden 1991, 78.

169 Pletneva 1958, 187, 202 (fig. 25, 26); Kałużyński 1983, 61.

170 Kałużyński 1983, 84; Khazanov 1984, 49.

171 Pletneva 1958, 186; Tryjarski 1975a, 498. For more in general on hunting among the Altai and Amur peoples: Sinor 1968, 119-127.

172 Olbricht, Pinks 1980, 117-118. Cf. Kałużyński 1983, 62-65; 1970, 28. The practice of group hunting was widespread among Eurasian steppe people. Moszyński 1996, 36; Dąbrowski 1975, 107; Szymański 1979, 71; Mukhamejanov 20oo, 288-289.

173 Kałużyński 1983, 63-64.
} 
to say to what extent these observations can be applied to the Pechenegs. It would seem, however, that we could assume they also most likely organized larger hunting expeditions. The Pechenegs probably also engaged in wildcrafting, but we are unable to say anything definite about this.

Agriculture is usually perceived as a complementary and less typical form of economic activity for nomads. However, they had to develop a means of obtaining agricultural products because some of these were essential to their lives. ${ }^{174}$ One way was simply to engage in farming, adapting it to a nomadic way of life. Examples of such practices are provided by data from cultural anthropologists and, in the case of historical societies, from written sources. In the mid-2oth century, the Selenga Mongols sowed rye, barley, and wheat on plots of land alongside a river that had been previously loosened with the help of a wooden lister plough. The thickest clods of earth were broken up by hand. Sowing was usually carried out in spring. The plots were left to grow over the summer and harvested in autumn upon the nomads' return. Mature cereals were picked like grass without the use of sickles. ${ }^{175}$ The Khalkha Mongols had a specific division of labour in their farming. Wealthy families entrusted the job of looking after their sown fields to fellow nomads who were poor and possessed no livestock. ${ }^{176}$ Very interesting information can be found in the account of the 15th-century Italian traveller Giosafat Barbaro. He claimed that in February the subjects of the Golden Horde who were engaged in farming were called upon to make preparations for the upcoming sowing period. In March, they sowed grain on designated plots of land, which were located two days away from their encampment sites at the time the call to prepare the plots was made. After completing their field work, they returned to their horde. When the sowed plants were ripe, they separated from the horde once again to harvest the crop. According to Barbaro, the Khan himself was said to personally oversee work in the fields. ${ }^{177}$ The information of the Italian traveller leaves no doubt that we are dealing with a method of tillage typical of nomads, while the involvement of the state apparatus and the ruler himself seems to prove that this form of economic activity, although supplementary, was very important for the Golden Horde Tatars.

In addition to cultivating their own plant products, steppe-dwellers also obtained them from settled populations, for whom agriculture was the main

174 Cf. especially Khazanov's general comments $\left(1984,5^{2-53)}\right.$. For more about the special case of the Tuvans, see Vainshtein 1991, 143-147.

175 Róna-Tas 1959, 443-465; Di Cosmo 1994, 1100.

176 Vreeland $1957,46$.

177 Io.Bar., 125 (text), 150 (translation). Cf. Zajączkowski 1968, 231. 
source of income. Contrary to stereotypical beliefs reinforced by some written sources, within the borders of the Great Steppe, which stretched from Manchuria to the Hungarian Plain, there were many enclaves inhabited by agricultural populations, some of which dated back to the Bronze Age. ${ }^{178}$ Their presence provided conditions for interaction between nomadic and settled communities. The nomads were thus able to purchase the crops they needed through trade or receive them in tribute. The latter method required the nomads to impose their political domination over the settled farmers. Among the many nomadic peoples who did so were the Xiongnu (Hsiung-nu), ${ }^{179}$ Scythians, ${ }^{180}$ European Huns, ${ }^{181}$ Ashina Turks, ${ }^{182}$ Avars, ${ }^{183}$ and Khazars. ${ }^{184}$ Agricultural products were also obtained from neighbouring sovereign states that were threatened by the nomadic invasions and purchased their security with annual 'gifts'. A similar course of action is well documented in the case of China, for which it was often more economical to pay the tribute demanded by steppe peoples than to respond in kind to their armed aggression. ${ }^{185}$ It is worth noting, however, that this method of obtaining crops did not play as large a role on the steppe as was once thought. ${ }^{186}$ Necessary agricultural products could also be acquired through trade. ${ }^{187}$

In considering the role of agriculture among the Pechenegs, we need to address an additional issue: the gradual reduction in the role of pastoralism and increasing importance of agriculture and other forms of economic activity in the steppe economy. Soviet researchers, including Aleksander Iakubovskii, have usually associated this process with feudalization and the emergence of a group of nomads incapable of supporting themselves from pastoralism alone, forcing them to cultivate the land, which entailed changes in their lifestyle. ${ }^{188}$ This kind of forced sedentarization occurred mainly among impoverished nomads, and those who fell victim to it generally regarded it as a temporary solution to their economic difficulties. As soon as their material situation

\footnotetext{
178 Di Cosmo 1994, 1096-1115.

179 Di Cosmo 1994, 1094; 2002, 169-170; Kradin 2007, 126-127.

18 o Khazanov 1975b, 427, 429-430; Di Cosmo 1994, 1110-1111.

181 Maenchen-Helfen 1973, 174-178.

182 Skaff 2002, 364-72; 2012, 65-71.

183 Szymański 1979, 66; Beranová 1986, 85-91; Pohl 1988, 189-195.

184 Noonan 2007, 207-244.

185 Dąbrowski 1975, 34; Barfield 1992, 46-47. The latter researcher emphasizes that the quantities of grain and wine delivered to Xiongnu, confirmed in Chinese sources, were sufficient only to maintain the court of their ruler.

186 Di Cosmo 1994, 1115-1118.

187 Liu Mau-Tsai 1958, I, 452-455; Jagchid, Symons 1989, 24-51.

188 Grekov, Iakubovskii 1950, 19; Pletneva 1958, 188; Fedorov-Davydov 1966, 199.
} 
somewhat improved, however, they tried to return to their previous way of life and the activities associated with it. Apart from an attachment to the native ethnos, a mechanism that fueled such a desire to return was the fear of being scorned by fellow tribesmen and the threat of exclusion from their community. We know that among the Oghuz those who ended their nomadic way of life lost some of their rights. ${ }^{189}$ An obvious and much stronger incentive to take up agricultural work was created by environmental factors. Both the Bashkirs and the Volga-Kama Bulgars found themselves in areas with insufficient pastureland and were forced to look for other ways to obtain food, including agriculture. An important factor favouring such a metamorphosis was close contact with settled communities, for whom land cultivation was the main source of income. ${ }^{190}$

In the case of the Pechenegs, farming was most likely practiced as a secondary form of economic activity. This conclusion is based not only on comparative data, but also on accounts found in written sources. It is more difficult to answer the question whether there were communities dependent mainly on farming among the Pechenegs or those people under their rule. During the early stages of the Pechenegs' history, there is no data indicating this. It is doubtful that the core of the ethnos was ever comprised of inhabitants of the oases of Transoxania. ${ }^{191}$ Not until the Pechenegs' migration to the Black Sea steppe were the conditions created for close contact with agricultural populations, in this case, people of the Dridu culture living on the Siret, Prut and Dniester Rivers. The nature of their relationship with the Pechenegs is unclear. It seems, however, that until the 11th century, when the agricultural population began to withdraw from the lower reaches of the rivers, the relations between the two communities may have been good. ${ }^{192}$ It cannot be ruled out that the steppe-dwellers imposed some form of subjugation on the Dridu population, though the political structure of the Pechenegs seems to exclude a particularly strong and burdensome form of subjection. Political domination may have been accompanied by the acquisition of agricultural produce through tribute or forced unequal trade, the latter of which is confirmed by archaeological sources. ${ }^{193}$ Plant products could also be obtained by the Pechenegs through

\footnotetext{
189 Agadzhanov 1969, 109; Khazanov 1984, 82-84. For a similar observation about the Scythians: Khazanov 1975, 148-149.

19 o Pletneva 1958, 188. Por. Cf. Rudenko 1955, 61-65.

191 Cf. discussion in Chapter 3 of the present book.

192 Diaconu 1970, 37-48; 1975, 235-237; Spinei 1975, 271-276; 1986, 103; Dobroliubskii 1986, 24; Paroń 2009, 458-46o.

193 Spinei 1975, 271-273; 1986, 103.
} 
external trade, which has been confirmed in the case of Byzantium and Rus'. We will return to this issue later in this chapter.

Close contact with people with distinctly different cultures apparently did not result in broad cultural change among the nomads. The natural conditions of the Black Sea steppe were conducive to animal breeding and did not force them limit this form of economic activity in favour of others. Moreover, the intensity of contacts between Dridu and Pecheneg farmers was probably not as high as in the case of the Danube Bulgars and the Slavic population subordinate to them. In addition, a sedentary way of life and the agricultural activities that accompanied it were generally disliked by nomads, which meant that the process of their sedentarization and agrarianization, even in conditions that were exceptionally favourable to this, progressed slowly. This situation was probably the same with the Pechenegs. It is striking that the first mentions of their practicing tillage date back to the mid-11th century, i.e., the period just after they left the Black Sea steppe. John Skylitzes' chronicle tells us that after the entire ethnos had entered the territory of the Byzantine Empire and formally surrendered to Emperor Constantine IX Monomachos, the Pechenegs were settled around three places in the territory of today's Bulgaria, Northern Macedonia, and Serbia (Sofia, Ovče Pole, and Niš). They were required to pay tribute and cultivate the land there. They did so for a period of time, but soon rose up in rebellion and apparently abandoned the occupation. ${ }^{194}$ In Anna Komnena's

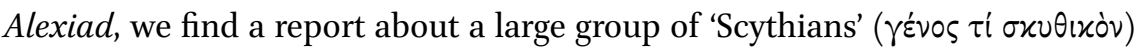
crossing the Danube in 1085. In the breaks between military campaigns, they were said to plough and sow millet and wheat. ${ }^{195}$ These 'Scythians' are usually identified as Pechenegs; ${ }^{196}$ however, the date of their migration (almost 40 years after the main wave of Pechenegs) and the formulation used by the scholarly Byzantine princess suggest that this group may have been a mixture of nomadic ethne withdrawing from the Black Sea steppe under pressure from the Cumans. Pechenegs may have been present during these events depicted, but we do not know what role they played in them. We must therefore treat the above-mentioned report with great caution, because we are unable to state to what extent it concerns the Pechenegs themselves. It is interesting to note that these 'Scythians' practiced ploughing, because it proves that they used more sophisticated methods of tillage. However, it is not advisable to attribute too much importance to agriculture in their economy, if only because of the fact

\footnotetext{
194 Io.Scyl., 459, 461; Wortley 2010, 430, 431.

195 An.Kom., VI 14.1 (p. 199); Sewter 2009, 182. Cf. also Chapter 7 of the present book.

196 Macartney 1929, 349; Tryjarski 1975a, 527.
} 
that Anna Komnena's account shows that they engaged in it on a casual basis during breaks between plundering expeditions. ${ }^{197}$

The information from both sources refers to the final chapter in the Pechenegs' history, after they were expelled from the Black Sea steppe and forced to seek shelter in the territory of neighbouring countries, mainly Byzantium. In addition to undergoing political change, they also experienced changes in their natural environment: they found themselves in areas with limited possibilities for continuing to practice extensive pastoralism. Given this situation, the importance of agriculture - thus far regarded as a secondary branch of their economy - certainly increased. It cannot be ruled out that this shift had already begun somewhat earlier, during their stay on the Black Sea steppe. The defeats suffered in the early-11th century in battles with Rus' and the Uzes had caused the Pechenegs to lose some of their pastures and herds, which, even if accompanied by a significant loss in their population, must have made it difficult to provide for themselves. This most likely forced them to make up for these shortages through plunder, which is best evidenced by their invasions of the Balkan provinces of Byzantium in the 1020s and 1030s. ${ }^{198}$ The defeats mentioned above also led to a significant impoverishment of the Pechenegs. In comparison to earlier periods of prosperity, there appeared a greater number of déclassé nomads, for whom agriculture probably provided an essential means of support. However, the cultural changes outlined here, especially as depicted in the information provided by Skylitzes, were adopted with great reluctance.

Crafts were also a part of the Pechenegs' economy. A more detailed description of its characteristics, however, requires a few introductory remarks. It is easy to augment the stereotypical image of a nomad as a destroyer and plunderer with an equally distorted vision of him being a versatile producer. It is hard to deny that the level of production on the steppe often did not equal that of the craftsmanship in settled communities, especially when the latter were represented by highly developed civilizations (China, Byzantium, Persia).

197 Spinei 2009, 227. The researcher assumes that the 'Scythians' described by Anna Komnena could not have been the Pechenegs, but were rather members of a community that lived in the area of the Paristrion province and joined immigrants in attacks on the Byzantine Empire. However, this reasoning contradicts the account of Anna Komnena, who clearly states that it was newcomers from across the Danube who worked the land before they invaded the provinces of the Empire. Their modus operandi seems to fully match that of the nomads who entered the Balkans. They probably came in winter or autumn, taking advantage of the freezing of the Danube, in spring they were able to cultivate their fields, and then, in summer or early autumn, organize a military expedition. Komnena's 'Scythians' were therefore a nomadic group, but it is difficult to identify them precisely.

198 Cf. Chapter 6 of the present book. 
The desire to obtain various luxury goods, rare among nomads, is a very frequent motif in the literature of neighbouring civilizations. It cannot be denied that the development of more sophisticated forms of artistic crafts was often possible in nomadic communities thanks to the acquisition of technological from more developed areas. These 'borrowings' were sometimes achieved by means of brute force through the abduction of experts in certain types of craftsmanship. ${ }^{199}$ Yet, it is hard not to notice that the inhabitants of the steppe were also able to produce very artistically sophisticated items. The conditions for the development of highly developed crafts, however, were created only within nomadic early-state organisms. In such societies, there existed an elite with a strong interest in manifesting its prestige that was able, thanks to its social and economic position, to create the conditions necessary for the operation of permanent specialized craft workshops. These were often established in centres which functions as a kind of capital, or central hub, for a nomadic empire. ${ }^{200}$ In the case of the egalitarian and segmented political organisms created by the Pechenegs, the existence of such a production centre for luxury craftsmanship is much less likely. This does not mean, however, that specialized production was completely alien to them. It must have existed, though on a smaller scale. The Pechenegs were able to process certain types of nonferrous metals, especially silver, and to a lesser extent, gold. ${ }^{201}$ According to the Muslim authors mentioned earlier in this study, whose data refers to the gth century, affluence among the Pechenegs manifested itself in the possession of numerous gold and silver vessels and silver belts. ${ }^{202}$ Appliqué work on these

199 Małowist 1976, 541, 543, 553, 554. After they had seized a city, the Mongols usually spared the craftsmen, who were distributed among the dignitaries of the empire and usually taken to the east. Cf. also data from William of Rubruck on the settlement of the Teutons who lived in the town of Talas ( 20 days from Samarkand), who were then transferred to the town of Bolaq, located a month's journey west, where they mined gold and forged weapons for Möngke Khan. The Franciscan also mentions several times a Parisian goldsmith, master Wilhelm Buchier, who worked for Möngke in Karakorum. Rubruck, XXIII 2-3 (pp. 224-225), XXIX 3 (p. 253), XXX 2-3 (pp. 276-277). Marcin Broniewski, Stefan Batory's envoy to the Khan of Crimea, claims that the Tatars were not involved in crafts or trade. In the Khanate, these economic activities were left to Christian slaves and to Turks, Armenians, Jews, Circassians, Petyhorcy, Philistines and Roma. Broniewski, xxıII (Latin text), 70 (Polish translation).

200 Małowist 1976; Khazanov 2005, 168-172; Pohl 20o8b, 97-120.

201 Tryjarski 1975a, 533.

202 Gardīzī: Martinez 1982, 152; Göckenjan, Zimonyi 2010, 165; Bakrī: Kunik, Rozen 1878, 59; Göckenjan, Zimonyi 2010, 222 (Bakrī writes about richly decorated, not silver belts); Marwazĩ: Minorsky 1942, 33; Göckenjan, Zimonyi 2010, 250 (Marwazī mentions the Pechenegs possessed silver and gold, with no indication of the form in which these metals were found in the steppe). Cf. Zachoder 1967, 74 . 
latter items could have indeed been made by craftsmen living on the steppe. ${ }^{203}$ Archaeological evidence attributed to the Pechenegs also indicates their ability to produce other silver, and much less often gold, jewellery (pendants, bracelets, earrings, rings, appliqué work on horse tack). ${ }^{204}$ However, they were less likely to make gold or silver vessels on their own. ${ }^{205}$

Contrary to the information found in written sources, the archaeological materials attributed to the Pechenegs are most often ornaments made of bronze. This applies to practically all of the above-mentioned categories of item, from appliqué work on belts to the decoration on horse tack. ${ }^{206}$

Iron was even more widely used in the Pecheneg economy. These steppedwellers mastered the technique of metal-working, which is evidenced by the frequent occurrence in their burial sites of iron elements of equestrian equipment (bit, stirrup), as well as some elements of weapons (e.g., arrowheads). ${ }^{207}$ According to Arab sources, the Pechenegs possessed many different types of weapons, ${ }^{208}$ though these brief references don't allow us to determine exactly what types are meant here. Among the archaeological materials discovered, apart from arrowheads, there have also been sabres, spearheads, axes and mace heads. ${ }^{209}$

In all past societies, the ability to smelt metals and produce and process metal alloys was connected with the specialization of production, and the

203 Garustovich, Ivanov 2001, 88; Ivanov, Krylasova 2006, 17, 25-26.

204 Chardaev 1991, 257; Garustovich, Ivanov 2001, 90, 93-94; Ivanov, Krylasova 2006, 17, 21-22, 28-30.

205 The question of the origins of the Treasure of Nagyszentmiklós, containing 23 vessels made of 18-22 carat gold, has yet to be resolved. However, Joseph Németh's hypothesis that it came from the Pechenegs has generally not been accepted. Németh 1932; 1971, 1-51. Cf. Csebe 1922, 213; Gyula 1974; Tryjarski 1975a, 596-597; 1975, 238-239; Waklinow 1984, 173-181; Erdal 1988, 221-234; Göbl, Róna-Tas 1995, 9-20; Bálint 1989, 187-192; 2010 (The treasure belonged to an Avar princely family from the 7 th-8th century, which lived in the southern or eastern part of the Carpathian Basin. 2010, 624).

206 Bronze was also used to make famous openwork pendants, in oval or heart-shaped form filled with ornamentation which is seen by some researchers as solar symbolism, while others interpret it as a motif of the tree of life, and yet others see it as a bird with open wings. Some pieces had an elongated ending with a hole at the end. Some archaeologists also consider the artifact to be a kind of grooming utensil (Russian: kopoushka). Garustovich, Ivanov 2001, 88-89; Ivanov, Krylasova 2006, 34. This pendant is often treated as a very important ethnic indicator pointing to the presence of the Pechenegs. For a skeptical stance on this subject: Curta 2013, 168-170; Fiedler 2013, 274-276.

207 Pletneva 1958, 156-159; Dobroliubskii 1986, 5o; Garustovich, Ivanov 20o1, 82-86, 87.

208 See footnote 841.

209 Garustovich, Ivanov 2001, 87-88. More on the above in the next section of this chapter. 
craftsmen who worked with metals enjoyed a special social status. ${ }^{210}$ The situation was no different among the nomads, where people engaged in smithery and jewellery production were excluded from the traditional division of labour into men's and women's activities. ${ }^{211}$ It cannot be ruled out that in addition to native craftsmen, foreign specialists also engaged in such work, either working among the Pechenegs or in close contact with them..$^{212}$

In addition to the above-described artisanal production, a common form of production among nomads was based on processing raw materials supplied by their extensive herds. As shown in written sources and in the field research of contemporary ethnologists, this served mainly to satisfy the nomads' own needs, and thus functioned within a division of labour into activities typical of men and women. It was characterized by a lack of specialization and was of relatively poor quality, i.e., lacking in artistic ambition. ${ }^{213}$ Due the abundance of leather among the Pechenegs, and their having mastered the skill of tanning, processing of this material was widespread. Women made leather sandals, boots, and probably some types of clothing, sewing them together with thread made of animal tendons. Leather was also used to make elements of horse tack, as well as bags, which replaced clay vessels, as these were not very useful in the conditions of nomadic life. ${ }^{214}$ The Pechenegs mastered the ability to make wool felt, which was used, among other things, to cover yurts. ${ }^{215}$ The Pechenegs were certainly also able to work in bone and horn, as is evidenced by the bone overlays of the composite bow ${ }^{216}$ found in grave inventories and, much less frequently, appliqué on quivers. ${ }^{217}$

210 Eliade 1993, 73-104. Blacksmiths and metallurgists, as 'masters of fire', enjoyed a status similar to shamans and sorcerers.

211 In the context of the division of labour: Szynkiewicz 1981, 56 (the researcher considers blacksmithing and goldsmithing to be specialized occupations, although practiced by men). On the subject of the special status of craftsmen dealing with metalworking in nomadic communities: Pohl 1988, 194. Cf. Tănase 2010, 213-225. The researcher argues that goldsmiths and blacksmiths enjoyed a high social status, but were not part of the ruling class.

212 Daniela Tănase points to the mostly wandering nature of craftsmen specialising in metalworking $(2010,224-225)$. V. Spinei $(1986,103)$ records the presence of individual objects of nomadic origin or their imitations in 'Dridu' culture sites as evidence of trade contacts. However, it is not impossible that this was in fact craftwork produced to meet the needs of the nomads.

213 Pletneva 1958, 19o; Moszyński 1996, 33.

214 Pletneva 1958, 190; Kałużyński 1983, 76, 78, 81.

215 Tryjarski 1975a, 529; Kałużyński 1983, 61.

216 Pletneva 1958, 159; Garustovich, Ivanov 20o1, 86-87, 92.

217 Garustovich, Ivanov 2001, 92. 
Judging by the writings of Byzantine authors, the Pechenegs were also skilled in carpentry. This is indicated by information about their use of carts, both as a means of transport and as defensive weaponry. ${ }^{218}$ Construction of such carts required mastering carpentry skills at a high level.

In contrast, their ability to make ceramic vessels was poorly developed. It is traditionally assumed that this was due to the fact that such items were not well suited to living conditions on the steppe. The frequent changing of encampments meant that fragile ceramics were constantly at risk of being broken during transport. Leather bags and iron boilers substituted for clay vessels. It is worth remembering, however, that in some political empires created by nomads, technologically advanced ceramic production was sometimes present, although foreign craftsmen and technology were usually responsible for their production. ${ }^{219}$ Steppe-dwellers themselves did not master the use of the potter's wheel, so even when we find dishes, these are either imported or examples of primitive ceramics made without the use of such a wheel. ${ }^{220}$ This also applies to the Pechenegs. Admittedly, clay vessels are sometimes found in the inventories of their graves, but only very rarely. Besides, these are usually primitive moulded pots. ${ }^{21}$ Large, richly ornamented clay kettles, widely found on the lower and middle Danube, and whose appearance in these areas had been associated by Petre Diaconu with the Pechenegs, ${ }^{222}$ can no longer be attributed to the nomads of the Black Sea steppe. These items appeared in the Balkans (Bulgaria) long before the Pechenegs. Moreover, to the east of the Dniester, that is, in the area they occupied for more than a century, not a single kettle of this type has been discovered.223

In general, the level of the Pechenegs' craftwork was not particularly high. Although it is hard to deny that they were familiar with its more specialized forms, they do not seem to have achieved a particularly impressive level of artistry. Their desire to own rare on the steppe luxury goods, which is often mentioned in written sources, is also clear. ${ }^{224}$ Even if we try to account for the bias of some authors who were overly inclined to attribute an insatiable greed

\footnotetext{
218 An.Kom., VII 3.7 (pp. 211-212); 7.2 (pp. 220-221); 10.4 (p. 231); Sewter 2009, 193, 201, 211.

219 The ceramic production of the Golden Horde is considered an example of this. Cf. Koval' 2005, 75-86; Lavysh 2013, 121-125.

220 Pletneva 1958, 19o; Kałużyński 1983, 80-81; Spinei 2009, 238.

221 Garustovich, Ivanov 2001, 89, 94; Spinei 2003, 100.

222 Diaconu 1964, 249-263.

223 Spinei 2009, 238; Curta 2013, 159-161.

224 See especially DAI, VI 8-9 (p. 52/3); VII 8-17 (p. 54/5). Cf. Paroń 2007a, 107-108.
} 
to all barbarians, and peculiarly to steppe people, ${ }^{225}$ it seems that behind a layer of literary topoi and stereotypes lay real-world experiences. The desire to obtain deficit goods grew as a result of contacts with settled communities with a significantly higher level of development in terms of material culture. This problem will be dealt with later in this chapter, so here we should limit ourselves to the observation that the desire to own luxury goods was one of the nomads' motives for carrying out looting raids against the peoples who produced these goods, this desire may have also been equally conducive to the establishment of trade contacts.

The economy of the Pechenegs, like that of most nomadic peoples, was not self-sufficient. This was not a feature typical only of steppe-people, because it is difficult to find a community that was able to satisfy all its needs relying solely on its own production, without the need to trade in goods or other means for supplementing its economic deficits. Nevertheless, extensive pastoralism made the nomadic economy particularly susceptible to crisis shocks, while hunting, gathering and primitive agriculture could not sufficiently compensate for its weaknesses to protect the steppe peoples from hunger, which, despite their indiscriminate diet, often plagued them. ${ }^{226}$ Threatened by a lack of food, nomads, according to Giovanni da Pian del Carpine, ate 'everything that could be eaten'.227 They did not refrain from eating the meat of dogs, wolves and foxes, the blood a mare releases when giving birth or even human lice. ${ }^{228}$ They were even credited with practicing cannibalism in cases of extreme hunger. ${ }^{229}$ While the eating practices of the Pechenegs may have seemed disgusting to an outside observer, ${ }^{230}$ they were probably dictated by extreme necessity. They

225 Cf. Sinor 1978, 171-182.

226 Kałużyński 1983, 71-72.

227 di Carpine, IV 7 (p. 248). 'Cibi eorum [Mongols - A.P.] sunt omnia que mandi possunt'.

228 di Carpine, IV 7 (p. 248).

229 di Carpine, IV 7 (p. 248). '[...] et in necessitate carnes humanas manducant'. Similar practices are attributed to the Cumans by William of Rubruck. Rubruc, I 12 (p. 171). '[...] et quando venerunt Tartari tanta multitudo Comanorum intravit provinciam illam [i.e., the steppe area of Crimea - A.P.], qui omnes fugerunt usque ad ripam maris, quod comedebant se mutuo vivi morientes, secundum quod narravit michi quidam mercator, qui hoc vidit quod vivi devorabant et lacerabant dentibus carnes crudas mortuorum, sicut canes cadavera'.

230 Cf. remarks of Michael Attaleiates, who states that the food of the Pechenegs is simply repulsive. Mich.Att., 52/53. 
were also said to eat lice, ${ }^{231}$ cats $^{232}$ and human meat. ${ }^{233}$ The last of these 'items' probably appeared in their menu only in the most extreme situations. ${ }^{234}$

Survival on the steppe was difficult, especially on the turn of winter and spring, when the provisions accumulated for the winter were exhausted, the animals could not be slaughtered, and their milk yields fell to a minimum. At that time, glazed frost was also experienced, which was extremely dangerous for livestock. ${ }^{235}$ However, if there were no major losses among the herds, those fortunate enough to survive until spring could now safely await the coming seasons. However, if their situation was worse, i.e., there were significant losses among the animals in their herds, the nomads would be threatened with famine throughout the coming year.

Faced with such a state of affairs, they were forced to look for additional methods of earning a livelihood. These included trade and organized plunder. The first practice should theoretically have limited the second, as the establishment of effective trade contacts was not conducive to a state of temporary or permanent armed conflict. Among some steppe peoples it seems that a specific evolution can be observed, consisting in a gradual reduction in looting attacks and their replacement with trade. The material gains acquired from plunder must have diminished over time, as it tended to either lead attacked communities to organize more effective defences or simply leave threatened areas. Looting attacks thus either no longer made sense or became a difficult and risky undertaking without any guarantee of success. ${ }^{236}$ Establishing trade contacts also had its positive sides for the settled communities neighbouring the nomads, because the latter, in having satisfied their needs through trade or forced tribute, lost one at their primary motives for organizing plundering expeditions.

\footnotetext{
231 LeoDiac., IX 12 (p. 157).

232 Ott.Fr., vi 10 (p. 272).

233 Ad.Brem., Schol. 17 (18), p. 8o. 'Mahari sunt populi Sclavorum, qui sunt ab oriente Behemorum, habentque in circuitu hinc Pomeranos et Polanos, inde Ungros et crudelissimam gentem Pescinagos, qui humanis carnibus vescuntur'. The consumption of corpses is attributed to the Pechenegs by Matthew of Edessa. Mat.Ed., 89 .

234 It is worth mentioning that pointing to cannibalism has a classifying value and indicates the extreme wildness of the Pechenegs and their distant geographic location, at the ends of the world. Cannibalism was also associated with extreme cruelty. Cf. Paron 2011, 131-132.

235 Khazanov 1984, 73.

236 Liu Mau-Tsai 1958, I, 452-455; Sinor 1972, 174-177; Gumilev 1997, 33.
} 
However, the economic weakness of the nomads posed a barrier to normalizing contacts. In conditions of equal exchange, they had less to offer to their settled trade partners. The assortment of goods they had to offer was limited to animal products, usually in the form of livestock. Of these, the steppe-dwellers could easily find buyers for their horses. Their endurance and ability to obtain food on their own were both widely appreciated. ${ }^{237}$ The nomad's mounts were also the only ones able to withstand the hardships of a journey through the steppe. However, these animals were practically all the nomads had to offer outside of surpluses of other animals from their herds. But the sale of an excessive number of animals led to disturbances in the herd balance, which usually had dire economic consequences. ${ }^{238}$ In addition, the position of the nomads was weakened by the fact that they were often more interested in trade than their settled neighbours. ${ }^{239}$

The weakness of the nomads' economy seems to have made them inclined to violence. The threat of invasion therefore did not disappear, but became a tool for establishing economic relations that were more advantageous for the steppe-dwellers. Through the skillful use of brute force, nomadic communities were able to transcend the limits of their economies by imposing forms of unequal trade on their neighbours, which was in fact a hidden form of tribute. The Pechenegs' military superiority not only provided a means of achieving political domination, but also opened the way for more effective use of trade relations. If a particular nomadic political organism ruled over an area through which important trade routes ran, it could use its political dominance to organize an extensive trade network. Manufacturing weaknesses were overcome through tributes provided by subjugated populations. In this way, nomadic communities could become not only the organizers of such trade, but also participants in it.

The Khazars provide a concrete historical example of such behaviour. After a period marked by plunder and conquest, they created an empire sometimes referred to as the Pax Chazarica, whose economy was based on proceeds received from trade along the Volga route and on tribute provided

237 Kałużyński 1983, 82. Steppe horses had been sold in China since at least the Han Dynasty (late 3rd century BC): Gumilev 1996, 23; 1997, 32; Di Cosmo 2002, 232 (the researcher emphasizes, however, that the Han started breeding their own horses very quickly); Jagchid, Symons 1989, 167-172.

238 Khazanov 1984, 204. The researcher cites the example of 19th-century Kazakhs, who were persuaded by the tsar's administrators, supported by merchants operating on the steppe, to sell such a large part of their herds that they could not naturally restore their original numbers. As a result, the breeders were ruined.

239 Khazanov 1984, 202. 
by conquered ethne. However, this system was created and supported by the rational use of violence. The security of trading operations depended on curbing the Khazars' warlike neighbours, including the Pechenegs. According to ibn Rusta, the iša, the Khazars' military chief, organized penal expeditions against them each year. ${ }^{240}$

The wealth and prosperity which, according to Muslim authors, the Pechenegs enjoyed in the gth century, when their lands were in the Transvolga, probably originated to a large extent from plunder. This is indicated not only by the above-mentioned comments by ibn Rusta, but also by other Muslim authors. The Pechenegs were said both to attack all the neighbouring peoples and be targets of aggression from them, as well. One Arab writer even states that all the neighbouring ethne attacked them, kidnapped them, and sold them. ${ }^{241}$ However, one can assume that the Pechenegs were not only victims of violence, but also provoked it and responded to it. It should also be assumed that the practice of kidnapping neighbours was not alien to them. Unfortunately, we are unable to say anything more about the involvement of the Pechenegs in slave trading apart from the fact that in later periods of their history they occasionally engaged in it. ${ }^{242}$

In the 9 th century, their role in the trade was probably still quite limited. It is significant that according to Muslim authors, the road from the Pechenegs' land to the Khazars led through 'forest and thickets'. In addition, these authors unanimously emphasized the aggressive, bellicose nature of the steppe people. This information, we should remember, came from merchants who reached the Pecheneg lands in spite of these obstacles. We should therefore assume that these lands were far from primary trade routes, though it is not possible to say the Pechenegs were not at all involved in such trade.

240 Rusta: ibn Rusta, 29; Göckenjan, Zimonyi 2001, 54. Cf. also Chapter 3 of the present book. 241 Gardīzī: Martinez 1982, 151; Göckenjan, Zimonyi 20o1, 164-165. Cf. Zachoder 1967, 72-74. In Martinez's translation, the Pechenegs are not victims of invasions by their neighbours, but they encourage neighbouring peoples to attack each other and supply them with slaves for sale.

242 Constantine Porphyrogenitus claimed that when Magyars or the Rus' are on a war expedition, the Pechenegs would easily invade their country and enslave their wives and children (DAI, IV 10-13 (pp. 50-53). It is reasonable to assume that the abductees were at least partly sold into slavery. John Skylitzes, on the other hand, clearly states that Kegenes, one of the Pechenegs chiefs either murdered or sold his compatriots whom he managed to capture, (Io.Scyl., 459; Wortley 2010, 430). Psellos attributed the same conduct to the Pechenegs (Mich.Psell., VII 69 (p. 242); Sewter 1953, 242). However, it is not possible to determine the scale of human trafficking or the degree of involvement of the Pechenegs in this practice. Akades N. Kurat claimed that the Rus' would sell slaves to the Pechenegs (Kurat 1937, 68). A sceptical stance on this issue: Golden 1991, 71 (n. 52). 
Their migration to the Black Sea steppe seems to have brought about significant changes. The Pechenegs probably did not completely abandon their looting raids. In fact, they may initially even have intensified them, wishing to recoup the material losses they suffered as a result of defeats they suffered at the hands of the Uzes and Khazars. ${ }^{243}$ The victims of their attacks may have been those living in territories belonging to eastern Slavs, Magyars or Danube Bulgars, or the area around the Byzantine city and thema of Kherson in Crimea. ${ }^{244}$ Constantine Porphyrogenitus also extensively described their attacks on Rus' traders travelling along the route 'from the Varangians to the Greeks'. The section running along the Lower Dnieper was an excellent place to prepare an ambush due to the need to portage river cargo around the Dnieper rapids. This provided the Pechenegs with an opportunity for organizing attacks on the Rus' traders. ${ }^{245}$ However, this case is somewhat special. It is worth remembering that the Rus' had entered an area controlled by the Pechenegs, and if they did so armed and against the will of the steppe-dwellers, the reaction of the latter described by Constantine vir seems to be fully understandable.

This period of intensified aggression, which may have been motivated by the Pechenegs' desire not only to compensate for previous economic losses, but also to define the boundaries of their new territory and sphere of influence, was probably followed by a period of calm in relations with their neighbours. Therefore, there seems to be no reason to blame the Pechenegs for causing the collapse of the trade route that led from Sarkel to the Lower Danube. ${ }^{246}$ On the contrary, there is much evidence of the steppe people's involvement in the trade it fostered. Although Constantine Porphyrogenitus mentions several times that the Pechenegs could pose a serious threat to neighbouring political powers, at the same time he cites interesting examples of their participation in trade. The Rus' are said to have purchased sheep, horned cattle and horses from them. According to the learned emperor, they did so because

243 Wojciech Szymański pointed to a similar phenomenon in the case of the Avars. (Szymański 1979, 67-68).

244 DAI, I-V (pp. 48-53). Cf. also Chapter 6 of the present book.

245 DAI, II 18-23 (p. 5o/51); IX 65-71 (p. 6o/61). Cf. Paroń 2007a, 103-105.

246 Tadeusz Lewicki does so (Lewicki 1956, 34). Cf. Pletneva 1958, 189, 191-192. E. Tryjarski finds ambivalence in the Pechenegs. The nomads were supposed to benefit from trade, but allegedly they could not refrain from looting merchants (Tryjarski 1975a, 541-545). For a similar judgment, but in a more general form, with the reservation that the trade in goods in the steppe did not cease completely: Spinei 2009, 243-244. P.B. Golden recognizes the occurrence of plunder and trade in the Pechenegs as two closely related forms of economic activity. The steppe people were supposed to plunder and then sell the booty (Golden 1991, 83); Noonan 1992, 320-321 (the trade on the steppe never ceased for a long time). 
there was a shortage of such animals in Rus. ${ }^{247}$ Witold Hensel has questioned the accuracy of this information. He pointed out that some East Slavic tribes (the Dulebi) had a significant number of horses at their disposal. Moreover, from at least the early 12 th century, these animals were quite widespread in Rus', which is proven by their wide use for cultivation on small farms. Hensel thus assumes that the Rus' purchased horses in order to maintain peaceful relations with the steppe-dwellers. This would therefore be an example of unequal trade, from which the Pechenegs were the main beneficiaries. ${ }^{248}$ The inhabitants of the thema and city of Kherson were also involved in trade with them. Constantine VII writes that the Pechenegs performed services for the Byzantine emperor and the Khersonites. Judging by the information contained in the source, this could not have been purely military in nature. It was decided by way of agreements concluded between the parties, represented on one side by a single Pecheneg, and on the other by a Khersonite. The partners agreed on the type and amount of payment the nomads were to receive for their services. The means of payment consisted of purple silk robes $(\beta \lambda \alpha \tau \tau i \alpha)$, silk

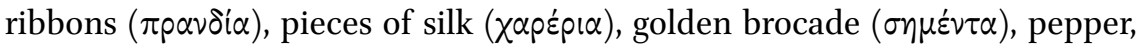
scarlet or Parthian leather and other luxury goods, which steppe people particularly desired. ${ }^{249}$ The type of agreement, one between two individuals, seems to clearly indicate that this was not a political or military agreement, but rather a commercial one. The Pechenegs hired by the Khersonites may have acted as intermediaries, pursuing their interests in 'Russia and Chazaria and Zichia ${ }^{250}$ and all the parts beyond, ${ }^{251}$ which would indicate the significant involvement of the nomads in the growing trade in goods in the Black Sea steppe region. According to information provided by Constantine VII, trade with nomads was very important for the Khersonites. They were said to purchase wax and animal skins from the Pechenegs, which they then sold in Byzantium. ${ }^{252}$ According to the learned emperor, if they could not find buyers for these goods in Romania, 'the Khersonites cannot live. ${ }^{253}$ The Steppe-dwellers supplied goods that

\footnotetext{
247 DAI, II 5-8 (pp. 48-51).

248 Hensel 1987, 113, 688. Cf. Noonan 1992, 308-309 (the purchase of these animals by the Rus' resulted from purely economic motivations).

249 DAI, VI (p. 52/3). Identification of goods used as payment to the Pechenegs: DAI-Com., 14-15; Litavrin, Novosel'tsev 1989, 289 (n. 5).

250 This toponym was used in European literature from the times of antiquity (Strabo XI 2.12) to the early $15^{\text {th }}$ century. This probably refers to the area of Cherkessia, especially the part located on the eastern coast of the Black Sea. Göckenjan 1997, 126-127.

251 DAI, VI 4-6 (p. 52/3).

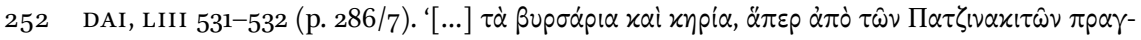
$\mu \alpha \tau \varepsilon \dot{o v \tau} \alpha \mathrm{l},[\ldots]$...

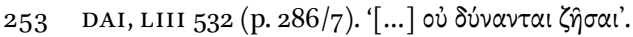


they probably could not produce themselves. Wax was a product of the forest economy which the Pechenegs could obtain from the Slavs ${ }^{254}$ or people of the Dridu culture. Animal skins, especially if there was a culling of fur animals, probably came from the Pechenegs' northern neighbours. We can only guess how they obtained both types of goods. Perhaps, at least in part, they were payment for animals delivered by the nomads to Rus' or tribute forced upon the latter under threat of invasion.

A brief mention that complements information provided by the Byzantine emperor in De administrando imperio can be found in the Arab historian al-Mas'ūdì's Golden Meadows, which also dates back to the mid-1oth century. In it he claims that merchants came to the Pechenegs from 'the country of the Khazar, Alans, Báb el-Awáb [Derbent] and others'.255

The information provided by both authors not only proves that the presence of the Pechenegs on the Black Sea steppe did not contribute to the collapse of local trade routes, but also seems to indicate their strong commitment to far-reaching trade. Their relations with the east, Khazaria, northern Caucasus (Derbent, Alania, Zichia), as well as with Rus', are particularly demonstrative of this. The Pechenegs were most likely included in the network of trade links formerly created by the Khazars, then extended to connect with the route 'from the Varangians to the Greeks'. Within this system the Pechenegs acted as intermediaries, a position facilitated by their location within the steppe niche, surrounded by powers interested in trade. It also seems that in certain circumstances it was much more convenient to order the delivery of a specific product from the nomads, as the Khersonites did, than to organize a risky expedition on their own. As we have seen, the political body of the Pechenegs lacked a clearly defined centre capable of organizing safe passage for merchant caravans through Patzinacia, following the example of the Khazars. A merchant travelling through these lands was probably exposed to threats similar to those experienced by Ahmad ibn Fadlan during his journey to the ruler of Volga-Kama Bulgars. In order to get permission to continue his journey, the Abbasid's diplomat was forced to repeatedly pay ransom to various local leaders of the Uzes or to ordinary petty intruders who stopped his caravan. ${ }^{256}$ The experience of ibn Fadlan shows that these were not insurmountable obstacles. He himself writes that in order to cross the lands of the Uzes, a Muslim had to first make friends with one of them. This friend would provide the traveller

254 Cf. Nosek, Szromba 1961, 88; Warnke 1987, 545; Litavrin 1999, 425-426; Schreiner 2013, 214. 255 al-Mas'ūdī, Les Prairies, II, 61; Pellat 1962, 178; Sprenger 1841, 449.

256 ibn Fadlan: ibn Fadlan, 206/207, 210/211, 212/213; Zeki Validi Togan, 1939, 26, 29, 31; Kovalevskii 1956, 127-128, 129-130; Frye 2005, 37-38, 39-41. 
with accommodation and food, lend him horses or camels, and grant him a loan. The animals and money were returned on the return trip. In exchange for this help, the Muslim brought gifts to his friend and his wife. ${ }^{257}$ Merchants coming to the Pechenegs from Islamic countries probably followed the same advice. Ahmad ibn Fadlan's account also shows that the journey through the steppe was a difficult logistical undertaking. Only nomads could provide proper means of transport. This circumstance additionally justified entrusting them with the delivery of necessary goods, as the Khersonites did.

The trade network created by the Khazars was devastated together with their state (in the year 965). A short time later, pressure from new Turkic ethne reduced the importance of trade routes running across the Black Sea steppe. These phenomena were also accompanied by the expansion of Rus', a consequence of which was the Pechenegs being deprived of their role as intermediaries in the trade in goods. The expansion of Kiev by Vladimir the Great, thanks to which the city became an important trade centre, was accompanied by its conquest and pillaging of Kherson in $989 .{ }^{258}$ Although the Crimean city survived the Rus' invasion, its role as an important trade centre was, at least for some time, severely limited. ${ }^{259}$ Rus' also managed to expand their borders to the northern shores of the Black Sea. The late 1oth century marks the beginnings of a settlement on Velikopotemkin Island at the mouth of the Dnieper River, which is identified with Oleshe known from Rus' chronicles. ${ }^{260}$ The Rurik Dynasty also took control of Tmutarakan, ${ }^{261}$ giving them not only the ability to trade through the Kerch Strait, but also direct contact with the northern Caucasus (mainly with Zichia-Circassia).

The Rus', especially Vladimir, managed to destroy or take control of the majority of the Pechenegs' trade contacts at the turn of the 1oth and nth centuries. In addition, the latter lost their hegemony on the Black Sea steppe as

257 ibn Fadlan: ibn Fadlan, 204-207; Zeki Validi Togan, 23; Kovalevskii, 126; Frye 2005, 35-36.

$25^{8}$ Andrzej Poppe assumes that this took place between April and the end of July in the year 989, although the Rus' arrived at Kherson no later than autumn of the year 988. Poppe 1976, 238-239; 1978, 18.

259 The conquest of the city by Vladimir's army resulted in the destruction of significant part of it and significant losses among the inhabitants. Kherson also stopped minting its own coins. Cf. Talis 1958, 114 (n. 54); Iakobson 1959, 65-66, 283; Poppe 1976, 239; 1978, 18; Bartoli, Kazanski 2002, 663. For a critical view on the link between the destruction of the city and Vladimir's invasion: Romanchuk 1989, 182-188 (the cause of the damage could have been an earthquake).

26o Sokul'skii 1980, 71. First mentioned in chronicles in 1084 (PVL 1, col. 205).

261 This event is usually dated to be very close to or simultaneous with the conquest of Kherson by Vladimir. Cf. Iakobson 1964, 59-6o; Gadlo 1994, 79-81 (late 986 to mid-987); Chkhaidze 2008, 286 (year 988). 
a result of the pressure from the Uzes, which probably further limited their participation in local trade. In the 11th century, especially in its second quarter, the Pechenegs again appear as plunderers. In the 1030s, the Byzantine Empire was particularly plagued by their aggression. As a result of Pecheneg attacks, the Empire's military assets on the Lower Danube were almost completely destroyed. ${ }^{262}$ These invasions were mainly aimed at plunder, as evidenced by the fact that the aggressor penetrated the Byzantium Balkan provinces evermore deeply. After 1036 the expeditions were halted for about one decade, which, as Paul Stephenson has hypothesized, may indicate the involvement of the steppe-dwellers in the trade of goods with the Empire's cities on the Danube. ${ }^{263}$ These trade ties could have been maintained or renewed after the Pechenegs entered the Balkans. However, this trade probably did not match the scale and intensity of the trade in which the Pechenegs were involved in the mid-1oth century.

\subsection{Military}

The Pechenegs, like most nomads, were known for their warlike character. Moreover, even in comparison to other steppe peoples, historical sources portray the Pechenegs as an ethnos distinguished by its bravery. Al-Mas'ūdī expressed this belief very clearly when he wrote:

The first of these nations has the name Bajna. The second is called

Bajghird the next nation is called Bajnāk, and is the bravest of the four. The fourth is called Nūkardah. ${ }^{264}$

The bravery of the Pechenegs is also noted by Constantine Porphyrogenitus. The scholarly emperor considered these nomads to pose a permanent threat both to the Byzantine Empire and to other neighbouring states and ethne, i.e., the Magyars, Rus', and Bulgars. ${ }^{265}$ In his account of the history of the Pechenegs in the mid-11th century, when they were already suffering serious defeats in battles with the Rus' and the Uzes, John Skylitzes wrote:

\footnotetext{
262 Cf. Chapter 6 of the present book.

263 Stephenson 1999, 46-47, 52; 2000, 86.

264 al-Mas'ū ūī, Les Prairies, II, 59; Pellat 1962, 177-178; Sprenger 1841, 445 (English translation has been slightly modified).

265 DAI, I-V (pp. 48-52); VIII (p. 58/9).
} 
The Pecheneg people are Scythians pertaining to the so-called 'Royal Scyths'. They are numerous and no other people of the Scythians is able to withstand them alone. ${ }^{266}$

Finally, thanks to Anna Komnena's Alexiad we learn that:

War is their [i.e., the Pechenegs' - A.P.] blood - they know how to arrange a phalanx. ${ }^{267}$

Military efficiency, as confirmed by these authors, became the main source of the political significance the Pechenegs enjoyed, especially in the 1oth century. Let us take a closer look at their martial prowess.

As was the case with many other nomadic ethne, the social organization of the Pechenegs roughly mirrored that of a military organization. ${ }^{268}$ In times of armed conflict, every man capable of bearing arms was expected to fight, and in the event of a particularly serious threat, women as well. ${ }^{269}$ Individual tribes formed military units, called 'arrows' $(o q)$. Their commanders were probably the tribal leaders, about whom we read in the Chapter 37 of De administrando imperio. ${ }^{270}$ We can also assume that the chief of the entire ethnos was elected from among this group. In the opinion of some researchers, the fact that almost the entire people was called to arms caused the armies of nomads to reach considerable size, which meant they were able to outnumber the enemy, this being one of the sources of the nomads' military success. ${ }^{271}$ This assertion is not completely misguided, though it seems that another effect, resulting from the fact that the social and military organization of the steppe peoples were synonymous with one another, was more important: namely, the remarkable ease with which they could mobilize large numbers of fighters in a short period of time. The decisive factor would thus be not so much the number of

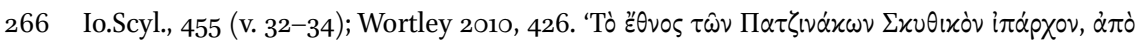

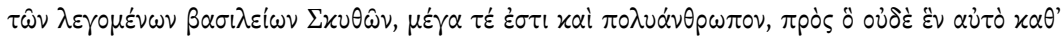

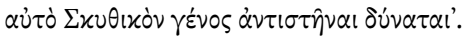

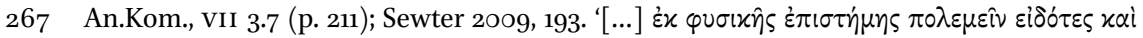
$x \alpha \tau \dot{\alpha} \varphi \dot{\alpha} \lambda \alpha \gamma \alpha$ i $\sigma \tau \alpha \sigma \theta \alpha \mathrm{l}[\ldots]$.

268 There is no separate native Turkic or Mongolian word for 'soldier'. The Turkic peoples referred to warriors with the word $e r$, which also means 'man, person'. Sinor 1981, 134; Golden 2011a, 90-91.

269 An.Kom., viI 6.6 (pp. 219-22o).Cf. Pletneva 1958, 196; Golden 2o11a, 91-92.

270 DAI, XXXVII (p. 166/7).

271 Pletneva 1958, 196. 
warriors, but rather the speed with which they were assembled, a product of their almost constant readiness to take military action. ${ }^{272}$

The question of the Pechenegs' potential mobilization capabilities is particularly difficult to answer. Although we have data on the number of warriors in their military units, these should be considered fanciful. ${ }^{273}$ Other estimates are more reliable if only because they are (sometimes by an order of magnitude) lower. It must be admitted, however, that we have no means of verifying these figures at our disposal, apart from the researcher's intuition. Nevertheless, it seems that the information contained in The Book of Precious Gems is worth closer consideration, as it allows us to indirectly estimate the strength of the Pecheneg army. We learn here that the army units expected to go on expeditions headed by the leader of the Magyars consisted of 20,00o horsemen. ${ }^{274}$ Ibn Rusta seems to be describing the state of affairs in the latter half of the ${ }^{\text {th century, }}{ }^{275}$ which is the period immediately preceding the Pechenegs' invasion of the Black Sea steppe. The latter assumption is of particular importance. If we take into consideration the fact that they defeated and drove away the Magyars, we can assume that they may well have had comparable forces at their disposal. This would mean that the size of their armies at the time of their arrival on the Black Sea steppe reached or slightly exceeded 20,00o. An additional premise confirming the previous conclusion can be found in Chapter 8

272 Moszyński 1996, 31. Lev Gumilev $(1997,33)$ notes that in the 2nd and 1st centuries BCE the population of the Xiongnu was about 300,000 people, while the population of the Chinese was almost 60 millions (sic!). In this situation, even taking into account the specificity of the internal organization of the nomads, the mobilization possibilities of the Han Empire were much greater. The Xiongnu, on the other hand, were able to prepare their forces for an effective attack much more quickly, which determined their success in battling this demographic colossus. Based on Martin Loewe's estimates, Thomas Barfield $(1992,49)$ presents more favourable demographic data for the nomads. The Xiongnu population was estimated to be around 1 million, while the Chinese were said to number around 54 million.

273 According to Skylitzes, the entire Pecheneg population, which under Tyrach crossed the borders of the Byzantine Empire in the middle of the 11th century, was said to number

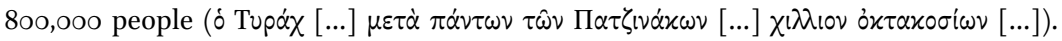
Io.Scyl., 458 (v. 44-45), Wortley 2010, 429 (an unauthorized revision by a translator to $80,000)$. This information was used by Omelian Pritsak $(1975,227)$ to estimate the size of the Pecheneg population; he obtained the rather fantastic number of 2.8 to 3 million people. The nomads are said to have had an army of 400,000 warriors at their disposal. The figure Pritsak provides is definitely inflated. Cf. Peter B. Golden's critical remarks (2011a, 108-109).

274 ibn Rusta: ibn Rusta, 33, 48-49; Göckenjan, Zimonyi 2001, 68 (cf. ibid. footnote 82: some Hungarian researchers have assumed that the number given by ibn Rusta constitutes $1 / 5$ of all adult Magyars.). Zakhoder 1967, 48-49.

275 Marquart 1903, 24-26. 
of De administrando imperio. Constantine viI describes the unsuccessful diplomatic mission of the cleric Gabriel who was sent to Magyars as an imperial emissary. His mission was to persuade them to attack the Pechenegs in order to seize their territory and then settle in the immediate vicinity of the empire. Gabriel was unable to complete the task. The Magyars were not interested in even considering any attempt at attacking their eastern neighbours. Most interesting is the reason they presented to the emperor's envoy. They stated they were not able to fight the Pechenegs, because, among other reasons, 'their people [were] numerous' ( $\lambda \alpha$ ò $\left.^{\prime} \pi \circ \lambda \dot{\nu} \varsigma\right){ }^{276}$ This last phrase should be understood as proof of the Pechenegs' numerical superiority; otherwise the concerns of the Magyars would seem inexplicable. Interesting data can also be found in Mas'ūdī's account of fighting at Walandar (W.L.nd.r.). The army of allied nomadic peoples was said to consist of 6o,ooo warriors. The author adds, however, that this was not the limit of their mobilization capabilities, as they were able to concentrate much greater forces, estimated at 100,000. ${ }^{277}$ This information should be treated with the utmost caution. According to Marquart's revisions, the units of two, not four steppe ethne took part in the Battle of Walandar. This would mean that in determining their combined forces, the two numbers

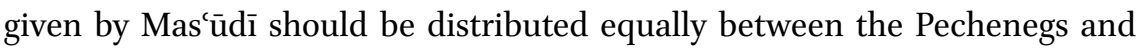
the Magyars. Therefore, the mobilization capacity of each ethnos would range from 30,000 to 50,000 horsemen. It seems, however, that during invasions the maximum number of Pecheneg forces oscillated around the lower line, as some warriors had to remain in their homeland to guard their encampments, property and defenceless elements of the population. ${ }^{278}$ Taking into account the above premises, we can assume that the Pechenegs were able to deploy a 20,000-30,00o-man army. ${ }^{279}$ However, these findings are subject to a number of reservations. First, they can only be safely applied to the Pechenegs' situation in the 1oth century, when they were at the height of their political importance. Moreover, the number obtained should be regarded as an indicator of the demographic potential of this steppe people, which, if necessary, might

276 DAI, VIII (p. 56/7).

277 al-Mas'ūdī, Les Prairies, II, 6o; Pellat 1962, 178.

278 Hansgerd Göckenjan, using the data on the Székelys community, assumes that about 1/3 of all warriors remained in such guarding roles. Göckenjan 1972, 105 .

279 This number is quite impressive, although it seems that the most powerful nomadic peoples had larger forces at their disposal: the Xiongnu had 50-6o,ooo warriors (Gumilev 1997, 33), European Huns, together with foreign auxiliary troops - 6o,ooo (Dąbrowski 1975, 100), the Avars - 50,0oo (Szymański 1979, 81), Batu Khan - 120,00o (Vernadsky 1953, 49. The researcher stresses, however, that its core field army, which could be used during operations in more distant areas, consisted of just over 5o,ooo warriors). Cf. Golden 2011a, 106-108. 
have been (but need not have been) realized for military purposes. Finally, an army of this type functioned according to the rules of an egalitarian society. Thanks to their ability to effect a general mobilization, they could assemble a major military force in a short period of time, but it could disintegrate equally quickly when the majority of warriors considered that the goal of the military action had been achieved. Engaging all or most of the ethnos for longer periods seems to have been possible only in extraordinary circumstances, in situations of extended and permanent crisis that threatened the very existence of the ethnos. The use of smaller units seems to be much more common, especially during foreign expeditions. Maintaining standing military contingents was possible and necessary once a nomadic community reached statehood. ${ }^{280}$

Apart from the ability to efficiently assemble large armies and outnumber weaker ethne, the tactics used by the Pechenegs were a crucial factor in their military successes. As in the case of most nomads, the speed and violence of the attack played a major role, as well as the extremely commonly used element of surprise. ${ }^{281} \mathrm{~A}$ rapid attack and immediate retreat after accomplishing the objective guaranteed that the attacked state or people would not be able to gather sufficient forces to pursue the aggressor and retaliate. Moreover, the panic caused by an unexpected attack gave a chance to safely make off with booty. ${ }^{282}$

Speed of movement was ensured by the use of cavalry as the only type of unit in the army. If necessary, in order to reach a maximum speed during a march, supply trains were abandoned in favour of transporting supplies on pack animals. ${ }^{283}$ The high level of endurance of steppe mounts gave them the potential to cover long distances without stops. It was enough for each warrior to lead a second saddled horse, so he could switch to it in order to let the other rest. Taking spare horses on military expeditions was a common practice among nomadic peoples. A Mongolian horseman went to war leading

\footnotetext{
280 Di Cosmo 2002, 179-183.

281 In his speech in honour of Emperor Alexios Komnenos (1081-1118), Bishop Theophylact of Ohrid compared the attack of the Pechenegs to a lightning strike. The attack was as troublesome, because of the losses that resulted, as it was quick, because of the attacker's sudden escape. Theoph.Achr., 221.

282 Kałużyński 1970, 9; Pletneva 1958, 198.

283 The occurrence of such a practice during the nomads' raiding expeditions seems to have been confirmed by Niketas Choniates' report on the Cuman invasion of the Balkan prov-

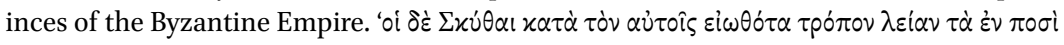

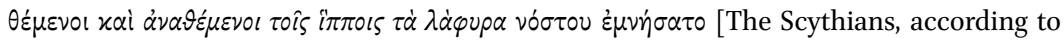
their custom, collected the available booty, loaded their horses with their spoils, and turned homeward]'. Nic.Chon., 93 (v. 77-79). Cf. Magoulias 1984, 54.
} 
from one to nine additional horses. ${ }^{284}$ According to Guillaume de Beauplan, each Tatar always led three mounts on a looting expedition. ${ }^{285}$ Thanks to such procedures, the cavalry could travel at an astonishing speed. ${ }^{286}$ During their journey, they made frequent but short stops - though after covering longer distances they usually rested for a few days. ${ }^{287}$ Long forced marches usually led to losses from attrition, meaning only a small part of the army ultimately reached the designated destination, so such a grueling pace was imposed very rarely. 288

In order to make better use of the element of surprise, an invasion was usually carried out when the opponent's main forces were away on a war expedition. This method was often utilized by the Pechenegs. This is how they inflicted a devastating defeat on the Magyars. Thanks to Constantine Porphyrogenitus, we know that they did the same during their invasions of the Rus'.289 The information provided by the scholarly emperor is confirmed by The Tale of the Bygone Years, which describes the Pecheneg attack of 968, undertaken while the main forces of the Rus' were fighting in Bulgaria. 290

Each military expedition was probably preceded by scouting, the aim of which was to examine the territory to be attacked and the forces of the opponent had stationed there. We know that some steppe peoples, especially the Mongols, mastered this aspect of the art of war. ${ }^{291}$ All sorts of information was collected that would allow for a determination of the level of the enemy's military preparedness. They also examined the political situation. The Mongols were able to take advantage militarily and diplomatically of the existence of antagonistic groups within an enemy state. ${ }^{292}$ In the case of the Pechenegs, preceding a military expedition with such sophisticated diplomatic manoeuvres seems rather unlikely due to the lack of a state apparatus capable of

\footnotetext{
284 Göckenjan 2000, 189.

285 Beauplan, 66.

286 Kałużyński 1983, 83. Dąbrowski $(1975,109)$ refers to information provided by Miklos Jankovich $(1968,223)$, according to which during the invasion of Hungary in 1241, the foreward guard of Batu was said to cover a distance of $480 \mathrm{~km}$ in three days, which would mean that the Mongolian formations were able to travel at a speed of up to $160 \mathrm{~km}$ per day. Information of this kind should be treated with great caution, even if it is close to the truth. Achieving such a pace is absolutely exceptional, even for nomads.

287 Beauplan claims that the Tatars stopped every hour for 15 minutes. Before entering the enemy territory, they rested for $2-3$ days. Beauplan, 66 .

288 Cf. Maron 2001, 116-120. Based on modern examples, the author considers a number of myths concerning the mobility of nomadic armies.

289 DAI, II (pp. 48, 50), IV (pp. 50, 52).

29 O PVL 1, AM 6476 (968), col. 65-67.

291 Olbricht, Pinks 1980, 185. Cf. Kałużyński 1983, 279; Göckenjan 200o, 191-193.

292 Kałużyński 1983, 274; Göckenjan 200o, 189-19o.
} 
planning and directing such activities. However, more modest intelligence activities should be considered a possibility, including observation of military movements on the steppe and along their territory's borders, and taking prisoners who could serve as sources of information or guides during an invasion. In this context, the results of an analysis carried out by Joseph Németh and Karl H. Menges of the names of the Pecheneg geneai recorded in De administrando imperio seems very useful here. One of them, which according to Constantine Porphyrogenitus was part of the left wing, was called Talmat (full version of the ethnonym: Borotalmat). ${ }^{293}$ According to a reconstruction carried out by these researchers, the ethnonym in its original version was tolmač/ talmač, which means 'translator, dragoman'. The word allegedly comes from the Turkic til, which has the double meaning of 'language, speech' and 'spy'. 294 These findings lead to the thesis that the Talmat-Tolmač tribe could carry out intelligence activities during the Pechenegs' military expeditions. They probably also acted as the forward guard during a march. Information obtained through scouting was of key importance for the success of both military campaigns and simple looting raids. It also often determined whether a planned military undertaking would be successful.

It is generally believed that the season when nomads usually took offensive action was early autumn. This was supposedly determined by the condition of the combat mounts, which by that time had regained their full strength after a very harsh winter thanks to the abundance of spring and summer feed. ${ }^{295}$ The time of year also guaranteed easy access to feed for horses. It cannot be ruled out that the purpose of the attack also played a role. If the goal was to obtain supplies, such as agricultural goods the nomads often lacked, then seizing it became possible only after the harvest, i.e., in early autumn. In the case of the Pechenegs, the direction and moment of an attack was probably also determined by the proximity and availability of the enemy's territory. Svetlana A. Pletneva claims that their invasions on the Rus' usually took place in the summer, when they were camping near the borders of the Kievan state. ${ }^{296}$ However, military expeditions were also organized in winter. Two factors seem to have been decisive in initiating them. First, the winter cold made it easier for nomadic forces to enter areas that were not accessible at other times of the

\footnotetext{
293 DAI, XXXVII (pp. 166, 168).

294 Németh 1921-1925, 223; 1930, 30, 33; 1932, 50; Marquart 1929, 84-85; Menges 1944-45, 261263. For a sceptical position: Vörös 2002, 624.

295 Olbricht, Pinks 1980, 53-54. Cf. Kałużyński 1983, 82.

296 Pletneva 1958, 200.
} 
year. ${ }^{297}$ Second, shortages of provisions, which were more pronounced during the winter months, likewise forced them to undertake looting expeditions. In Skylitzes' chronicle we find two mentions concerning winter invasions by the Pechenegs of the Balkan provinces of Byzantium. In both cases, there existed a rather special circumstance, namely the freezing of the Danube in its lower course. As a result, the nomads had easy access to areas on the other side of the river. ${ }^{298}$ A similar expedition in early autumn required a difficult crossing, the inconvenience of which became particularly acute during the retreat, when the nomads were burdened with the booty they had seized. ${ }^{299}$

The element of surprise, which gave the Pechenegs a tactical advantage over the enemy, was often achieved thanks to their use of ambushes. Their attacks on Rus' travellers making their way to Constantinople along the route 'from the Varangians to the Greeks' have already been mentioned. The final section of the route, due to the rapids on the Dnieper River, created excellent conditions to ambush the enemy. As we learn from Constantine Porphyrogenitus' account, the dugout canoes (called 'monoxylas') used to carry cargo on the river had to be ported in the area of the rapids. The Rus' would pull them ashore and carry them along with their cargo around the rapids and then continue their journey by water. It was at this moment when the Pechenegs would make a surprise attack. ${ }^{300}$ Prince Sviatoslav lost his life in such an attack while returning to Rus' in 972 after an unsuccessful expedition to the Balkans. ${ }^{301}$

Apart from offensive tactics, which assumed the Pechenegs taking the initiative, they were also often forced to adopt a defensive approach. A number of campaigns undertaken against them by the Byzantine Empire in the latter half of the 11th century provide evidence that, when forced to defend themselves, they were also able to demonstrate significant military skills. The steppe-dwellers avoided open battles when the enemy had a tactical advantage. In times of danger, they were able to disperse quickly, making it difficult to combat them effectively. Delaying a decisive confrontation, they used hit-and-run tactics, defeating weaker enemy units that strayed from the main forces. Examples of such behaviour can be found in Anna Komnena's Alexiad. During the 1087 campaign, Alexios Komnenos crossed the Balkans and reached the area of the Dristra fortress, having travelled dangerously far

\footnotetext{
297 Cf. a report by Guillaume Beauplan on Tatar invasions in winter, the organization and course of which differ from those in summer. Beauplan, 65 .

298 Io.Scyl., 399 (v. 3-5), $45^{8}$ (v. 39-46); Wortley 2010, 376, 429; Io.Maur., 144-145.

299 This does not mean, of course, that steppe people were unable to cross a major river. Cf. Sinor 1961, 156-179; Golden 2011a, 113 .

300 DAI, II (p. 5o/1), IX (pp. 6o-63).

301 PVL 1, AM 6480 (972), col. 74. Cf. chapter 5 of the present book.
} 
from his supply base in Thrace. The Pechenegs managed several times to intercept the Byzantine units sent to bring horse feed. The course of events that followed showed that once the nomads had achieved a tactical advantage over the enemy, they initiated combat. The battle took place near Dristra, and by the time it had ended, the Byzantines had suffered a crushing defeat, which Alexios Komnenos was fortunate to survive. ${ }^{302}$ This battle was significant not only as a proof of the Pechenegs' ability to achieve and make use of tactical superiority, but also as an example of the combat methods they used in open battle. This is what we read in Book vil of the Alexiad:

The Scythians also prepared for the battle [...]. So, after placing ambushes, binding together their ranks in close formation, making a sort of rampart from their covered wagons, they advanced en masse against the emperor and began skirmishing from the distance. ${ }^{303}$

The quote above quite unambiguously confirms that the Pechenegs used wagon forts during the battle. The effectiveness of these kinds of tactics is best evidenced by the outcome of the aforementioned battle. More information about the tactics used by the Pechenegs in open battles can be found in al-Mas'ūdì's account of a clash at the Greek stronghold Walandar. The Muslim writer does not mention the use of wagon forts by the allied forces; instead he points to the dominant role of the cavalry. It was said to be organized into squadrons of 1,000 horsemen each. ${ }^{304}$ The battle began with an attack by the Pechenegs' light cavalry, which, without engaging in close combat, approached the enemy's line and carried out an archery attack. ${ }^{305}$ This strike was carried out with the use of a small part of the nomadic force. The attack of the cavalry caused some confusion among the Greeks, who ultimately decided to engage the enemy. Light cavalry squadrons fired with their bows on the Byzantines as they attacked the main body of the nomad forces, which was not yet engaged in the fighting. These forces responded to the Byzantine army's attack first by

\footnotetext{
302 An.Kom., VII 2-3 (pp. 204-214); Sewter 2009, 187-196.

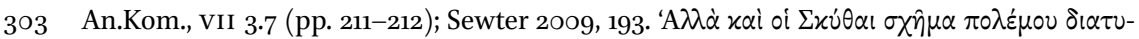

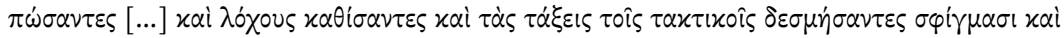

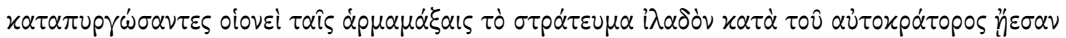

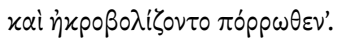

304 This would probably be the only example of a Pecheneg application of the decimal system in their army's organization, a system that was widespread among the Altaic peoples and beyond. Cf. Göckenjan 1980, 51-86.

305 We are most likely looking here at 'caracole tactics', commonly known on the steppe. Cf. May 2007, 72-74.
} 
shooting arrows, and then engaging in a direct confrontation, which halted the enemy's attack and routed their forces. The nomad warriors began a pursuit, during which the Greeks suffered considerable losses. ${ }^{306}$

The combat methods used by the Pechenegs in both battles were similar to those commonly utilized by other Turkic peoples. Teresa NagrodzkaMajchrzyk states that in battle the Khazars also used light carriages tied together with ropes. ${ }^{307}$ Attacking the enemy with just a part of one's forces, and thus the use of a tactical reserve, has been confirmed for both the Avars and the Mongols. ${ }^{308}$ The nomads were also familiar with grouping cavalry into units thousands strong, and the existence of two types of cavalry, i.e., light and heavy. ${ }^{309}$ Finally, their military tradition also included arranging armies into a two-wing formation. ${ }^{310}$

Both examples presented above do not confirm that the Pechenegs used a 'feigned escape' manoeuvre, a very popular tactical trick among steppe peoples, the aim of which was to lure the enemy into an ambush and attack with one's main forces after the enemy had loosened their formations during the course of pursuit. ${ }^{311}$ This does not mean, of course, that the Pechenegs did not know about this kind of tactical manoeuvre. Paradoxically, however, the opposite situation was documented, when their forces were lured into a trap and annihilated by the Byzantines, who in the initial phase of the battle feigned their retreat. This happened during the Battle of Arcadiopolis (970), during Sviatoslav Igorevich's Balkan campaign. ${ }^{312}$ Concluding our reflections on the tactics used by the Pechenegs in open battles, it should be noted that in the event of failure in their attacks, in order to avoid complete defeat, they usually opted for an immediate retreat. ${ }^{313}$

The only type of troops used in the Pecheneg army was that of cavalry. This by no means indicates that nomads never fought on foot. It is known that Avar horsemen would assume an infantry mode whenever they wanted to storm Byzantine fortresses. ${ }^{314}$ Anna Komnena writes that Emperor Alexios was attacked by 'three Scythian infantrymen' during the battle of Dristra. ${ }^{315}$

\footnotetext{
306 al-Mas'ūdī, Les Prairies, 62-63; Pellat 1962, 178-179. Cf. also Marquart 1903, 65 .

307 Nagrodzka-Majchrzyk 1975, 440.

308 Szymański 1979, 88; Pohl 1988, 172.

309 Tryjarski 1975a, 557; Gumilev 1993, 67-68.

310 Tryjarski 1975a, 557; Marquart 1903, 65 .

311 Kałużyński 1983, 273; Pohl 1988, 172; Maroń 20o1, 54-56, 72; Golden 2011a, 95-96.

312 Io.Scyl., 289-29o; Wortley 2010, 277.

313 See especially: Mich.Psell., VII 68 (p. 241); Sewter 1953, 242.

314 Szymański 1979, 88; Pohl 1988, 172 (The Avars did not like fighting this way). Cf. Sinor 1972, 172-173; Golden 2011a, 96.

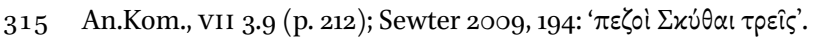


Nevertheless, these examples indicate that the transformation of cavalry into infantry was only temporary and forced by circumstances. Some researchers consider the existence of two types of cavalry to have been common among nomadic ethne. ${ }^{316}$ This view can only be supported if we assume that differences in social and economic status were reflected in the quality of one's weapons. The type of equipment used by a horseman would be not so much a consequence of military regulations, but rather of the natural processes of social stratification. According to experts on the subject, there was less a distinction in terms of equipment between heavy and light cavalry, as there was between the weaponry owned by the aristocracy and common members of the ethnos. ${ }^{317}$

Is an analogous division found among the Pechenegs? One can get such an impression based on al-Mas'ūdi's account of the Battle of Walandar, as well as from reports in Arab sources on the ostensible wealth of the Pechenegs, which was said to manifest itself also in the possession of a significant number of weapons. ${ }^{318}$ Data from archaeological sources, however, suggests we exercise considerable caution here. No blatant manifestation of social position comparable to phenomena observed in the Cumans has been found among the Pechenegs. Neither the size of graves nor the abundance and richness of their inventory can be compared to the mounds of the Cuman khans. Contrary to the assertions of Pletneva, ${ }^{319}$ it should be assumed that the Pechenegs were most likely a more egalitarian community. This of course does not exclude the existence of wealth and social differences among the Pechenegs. These were probably also reflected in differences in military equipment. However, their scale, especially in comparison with other steppe ethne, seems to have been visibly smaller.

Little is known about the way military formations were commanded during warfare. In order to ensure that the operation proceeded smoothly, the functions of chief commander were most likely entrusted to one of the tribal chiefs. Apart from the head of command, there was probably a group of minor chiefs who acted as commanders. We learn about their existence from the accounts of both Anna Komnena and John Skylitzes. ${ }^{320}$ We do not know what kinds of authority the head of command possessed. Could he impose the death penalty

\footnotetext{
316 Gumilev 1993, 67-68.

317 Świętosławski 2006, 103-104.

318 Gardīzī: Martinez 1982, 152; Göckenjan, Zimonyi 20o1, 165. Bakrī: Kunik, Rozen 1878, 59; Göckenjan, Zimonyi 2001, 222. Marvazī: Minorsky 1942, 33; Göckenjan, Zimonyi 2001, 25 O. Zakhoder 1967, 74 .

319 Pletneva 1958, 197.

320 Io.Scyl., 459 (v. 64-66); Wortley 2010, 429-430. An.Kom., viI 4.4 (p. 216); Sewter 2009, 197.
} 
for failure to engage in combat, insubordination or desertion? In the Mongol army, where the principle of absolute obedience to the orders of the commander applied, ${ }^{321}$ the chief commander of the Danube Bulgars also enjoyed a very broad range of powers. ${ }^{322}$ However, clear differences between the two ethne mentioned above and the Pechenegs, especially in terms of their sociopolitical organization, prevent us from drawing a simple conclusion by means of analogy. On the contrary, much seems to indicate that the chief commander was not fully independent and had to take into account the opinions of minor chiefs in the decision-making process. What is more, even when commanding corps he could not afford to completely disregard the will of rank-and-file warriors. The incident recorded by Anna Komnena, mentioned earlier in this chapter, provides clear testimony to this fact. In that dispute over the fate of captives, the harsh pragmatism of the chiefs was justified. The prisoners-ofwar offered a recruiting reserve that Alexios Komnenos could use to quickly rebuild his defeated army, which would give him an advantage in his fight with the Pechenegs. ${ }^{323}$ This example cannot be treated as a demonstration of a general rule. In particular, it should not lead us to the conclusion that the function of chief commander was of little importance and was not associated with any real power. The prestige of this position was of great significance. If the head of command proved his military talents, he could gain a reputation that, despite the limitations on his powers, would provide him with significant authority to enforce his decisions. ${ }^{324}$

From information provided by Muslim writers, we learn that the Pechenegs used banners or pennants which they attached to their spears and would raise during battle. ${ }^{325}$ Various iconographic sources also confirm the use of such combat signs by other steppe-dwellers. There is a representation of a horseman holding a spear with a piece of cloth attached to it on one of the vessels

321 di Carpine, IV 2 (p. 245), VI 2-3 (pp. 275-276). Cf. Kałużyński 1983, 262-263; Maroń 2001, 13 .

322 Tryjarski 1975, 315. Cf. Sinor 1981, 135-137; Golden 2011a, 93-94 (both scholars cite many examples concerning other peoples of Inner Asia which managed to develop political organisms of the imperial type).

323 An.Komn., VII 4.4; 6.1 (pp. 216, 218); Sewter 2009, 197, 198-9.

324 It is significant that Kegenes owed his political significance to military successes in clashes with the Uzes. He must have enjoyed considerable influence, since Tyrach, the leader of the entire Pecheneg people, saw him as a threat to his power. Io.Scyl., 455; Wortley 2010, 427 .

325 Gardizī: Martinez 1982, 152; Göckenjan, Zimonyi 2oo1, 165. Bakrī: Kunik, Rozen 1878, 59; Göckenjan, Zimonyi 2001, 222. Marvazī: Minorsky 1942, 33; Göckenjan, Zimonyi 2001, 25 o. Cf. Zakhoder 1967, 74. 
from the famous Treasure of Nagyszentmiklósz. ${ }^{326}$ A large pennant (banner?) can also be seen on a rock face in Pliska. A piece of fabric is attached to the upper part of the shaft held by a warrior. ${ }^{327}$ On one of the stone statues (baby) attributed to the Cumans, we find an engraving of a mounted warrior with a large pennant. ${ }^{328}$ Finally, illustrations in the Radziwitt Manuscript ${ }^{329}$ show armed groups of nomads, probably Cumans, headed by a standard bearer holding a pennant. These banners probably served as field signs, indicating the commander's location during battle. Pletneva posits that when the Cumans had fully readied themselves to fight, they would raise their pennants. ${ }^{330}$ It cannot be ruled out that the Pechenegs did the same. According to al-Gardizi, during battle they would also blow buffalo horns. ${ }^{331}$ These sounds were probably used, like banners and pennants, to send signals.

The combat methods characteristic of steppe peoples were related to their weapons, the most common element of which was the bow. It is hard to imagine any nomadic military formation without this weapon, and its use by the Pechenegs is reported in both narrative accounts and archaeological finds. Suffice it to point again to the information we have on the battles at Walandar and on the Dristra, where the role of the bow as an offensive weapon was confirmed. Bone overlays found in grave inventories ${ }^{332}$ allow us to assume that the Pechenegs used a form of composite bow. This bow was usually made of several types of materials, ${ }^{333}$ and when it was in a resting position, its limbs were bent away from the direction in which one pulled the string. This allowed more potential energy to be accumulated, thanks to which a much longer range was achieved than with longbows, which were more common in Europe. ${ }^{334}$ Archaeological findings indicate that Pecheneg arrowheads were mostly flat

\footnotetext{
326 Gyula 1974, fig. 147; Świętosławski 1996, 61.

327 Tryjarski 1975, 313 (fig. 10).

328 Świętosławski 1996, tab. IV, fig. 2.

329 Pletneva 1958, 198-199 (fig. 20-22), 202-203 (fig. 25, 27).

330 Pletneva 1958, 197.

331 Gardizī: Martinez 1982, 152; Göckenjan, Zimonyi 2001, 165. Al-Bakrī notes that the Pechenegs used trumpets instead of drums: Kunik, Rozen 1878, 59; Göckenjan, Zimonyi 2001, 222. Cf. Zakhoder 1967, 74.

332 Pletneva 1958, 156, 159; 1990, 46-48; Pálóczi-Horváth 1989, 18; Garustovich, Ivanov 2001, 87; Bisembaev 2003, 84. More generally: Sinor 1981, 139-140; Świętosławski 1996, 39-44; Loades 2016.

333 The precise species of materials varied according to region but all composite bows consisted of wood, horn, sinew and glue with either a bark or leather casing. Cf. Świętosławski 1996, 40; Loades 2016, 22-23.

The average range of the composite bow was about 350 meters. Świętosławski 1996, 41.
} 
and had a rhomboid shape. ${ }^{335}$ Hungarian sources provide evidence of the use of poison arrows by these steppe-dwellers. ${ }^{336}$

The Pechenegs used many other weapons as well. Michael Psellos gives us a most intriguing piece of information:

The only weapon they carry in their hands is the spear, their sole defensive armour. ${ }^{337}$

Apart from historical accounts, the fact that the Pechenegs used spears is also confirmed by archaeological sources. However, this type of weapon was not as widespread as one might think based on Psellos' account. Spearheads with a narrow, often polished leave and a massive bush have been found in Pecheneg graves. ${ }^{338}$ Findings of this kind are, however, quite rare, which allows us to assume that only well-armed steppe warriors were equipped with pole weapons. ${ }^{339}$

When it comes to bladed weapons, the use of sabres is well documented. ${ }^{340}$ Archaeological research tells us that these sabres were massive and quite wide and had slightly curved blades. They were no more than one metre in length. The handles were wooden, while the cross-guard was wooden or iron and

335 Pletneva 1981, 215; 1990, 44; Pálóczi-Horváth 1989, 16 (fig. 5), 18; Garustovich, Ivanov 2001, 87 (the most detailed information), 149 (fig. 20, the most common type fig. 11, 20, 22, 29, 33, 34); Bisembaev 2003, 83, 117 (fig. 15, 10); Świętosławski 2006, 89-93.

336 Chr.Hung., 348-349; Joh.Thur., I, 91.

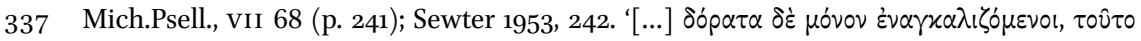

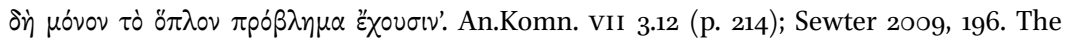
learned empress recalls her father being wounded by a spear wielded by a 'Scythian' (ie. Pecheneg). Muslim authors also talk about the spear as a weapon, though not the only one, of the Pechenegs. Gardizĩ: Martinez 1982, 152; Göckenjan, Zimonyi 20o1, 165. Marvazī: Minorsky 1942, 33; Göckenjan, Zimonyi 2001, 25 o.

338 Pletneva 1958, 158 (fig. 4); 1981, 215; 1990, 44; Garustovich, Ivanov 2001, 88, 15o (fig. 21, il. 3-5); Bisembaev 2003, 85, 107 (fig. 5.4); 112 (fig. 10). The latter did not find any artefacts in the area of western Kazakhstan which could be considered typical spearheads. Only two iron cones were discovered, which could have been the lower ends of spears. For more in general about pole weapons among the nomads of the Great Steppe: Sinor 1981, 141; Świętosławski 1996, 35-37.

339 Pletneva 1958, 197; 1990, 83.

340 PVL 1, AM 6476 (968), col. 67. A Russian source describes the ceremony for establishing friendship between the Kiev governor Pretich and some unknown Pecheneg prince. The ceremony was accompanied by an exchange of gifts, during which the nomad presented a sabre, a horse and arrows to Pretich, while he received chainmail armour, a shield and a sword. This story shows that in the late 11th century (the time when the oldest Russian chronicles were written) the sabre was perceived as a typical element of a steppe warrior's equipment. 
elliptical in shape. This type of weapons is found relatively rarely in grave inventories. It was therefore a valuable and scarce item, and possibly, as in the case of spears, a weapon primarily of the elites. ${ }^{341}$ In St. Bruno of Querfurt's Letter to King Henry II we also find a reference to swords, which were supposedly part of the Pechenegs' combat equipment. ${ }^{342}$ This type of weapon was indeed known to the steppe people. In his encyclopaedia, the 11th-century writer Mahmūd Kāšgarī often refers to the sword (qilič); judging from the frequent use of this word in that work, it must have been one of the most common melee weapons used by the Turks in that period. ${ }^{343}$ However, for the period in question (1oth11th century) the occurrence of the sword is poorly attested archaeologically in the western part of the Great Steppe. And yet nomadic formations were armed with swords in antiquity and in the early Middle Ages, and it was still the standard weapon of the European Huns and Avars. ${ }^{344}$ Nonetheless, swords dating back to a period later than the 7 th century have been discovered in the European part of the Great Steppe very rarely. How can Bruno of Querfurt's account be explained? Witold Świętosławski rightly notes that the inhabitants of Europe, who came into contact with nomads from Asia, were rarely acquainted with the terms for their weapons. ${ }^{345}$ Therefore, when describing them, they used terms typical of their own cultural milieu, noting only certain differences in the ones used by the steppe-dwellers. A good example of this is the characteristics of the sabres described by Giovanni da Pian del Carpine:

As for the wealthy, they [Mongols - A.P.] have swords pointed at the end but sharp only on one side and somewhat curved $\left[\ldots . .{ }^{346}\right.$

341 Pletneva 1958, 159, 197; 1981, 215; 1990, 43; Garustovich, Ivanov 2001, 87-88; Bisembaev 2003, 84-85.

342 Bruno, 100. '[...] mille securibus, mille gladiis super nostram cervicem euaginatis, in frustra nos concidere minantur'.

343 Tryjarski 1993, 239-240; Coman 1998, 579, 598 (Coman provides just one meaning for the Cuman word $q y$ lyč, qlyč, namely 'a sword'); Ching-lung Chen 1984, 31 (also assumes that the word keilin'ci in Chinese sources refers to a sword, although the description seems to indicate that it may have been a sabre). It must be admitted, however, that in Turkic (at least in modern Turkish) this word can also mean a sabre or a backsword. See Antonowicz-Bauer, Dubiński 1983, 142, 344, 372, 420. We are therefore faced with the question to what extent the lexis of a particular Turkic language represented apparent technical differences between different types of bladed weapons.

344 Szymański 1979, 84; Dąbrowski 1975, 110; Świętosławski 1996, 35.

345 Świętosławski 1996, 32.

346 di Carpine, vi 4 (p. 276); Dawson 1955, 33. 'Divites autem habent gladios acutos in fine, ex una parte tantum incidentes, et aliquantulum curvos [...]'. A very similar description of a sabre can be found in Chinese diplomatic reports devoted to the 13th-century Mongols. According to one of these, the steppe-dwellers used 'swords' that were light, narrow and 
These remarks are similar to those of Bruno of Querfurt's. It is worth noting that the situation in which he came into contact with nomadic weapons was not conducive to insightful observation. Therefore, what were placed at the necks of Bruno and his companions must have been sabres and backswords. The latter are not as well attested in archaeological evidence, but, due to their straight blade they bear a closer resemblance to swords. ${ }^{347}$

The Pechenegs were also familiar with blunt weapons. St. Bruno of Querfurt's Letter to King Henry II contains information on axes, ${ }^{348}$ which in this case is attested in archaeological records. ${ }^{349}$ The steppe people in question used simple battle axes, though only occasionally. Among rank-and-file warriors, both the wand (bulava) and club (buzdygan) were common weapons. ${ }^{350}$ Other weapons with which warriors were likely to be commonly equipped included combat knives, ${ }^{351}$ as well as lassos, which were used for securing captives during battle.

An interesting, though somewhat unclear account of the use of another type of weapon is provided by Anna Komnena:

It was his [Migidenos' - A.P.] son who in the war which broke out later charged fiercely against the Pechenegs [...]. As he swept past, he was dragged by an iron grapple inside the circle of wagons by a Scythian woman $[\ldots] .352$

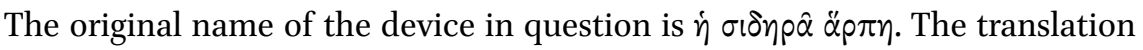
by E.R.A. Sewter quoted above is acceptable, but it should be noted that the

curved. Olbricht, Pinks 1980, 72. In a second report we read that they used, like the Uygurs, curved sabres, which were light, nimble and very sharp. Their handles were small and narrow, so that they could be easily use for fencing. Olbricht, Pinks 1980, 174. Thomas of Split also mentions the curved swords (falcati enses) of the Mongols. Tho.Arch., 282.

347 Świętosławski 1996, 30-35.

348 Bruno, 100.

349 Pletneva 1958, 157 (fig. 3, 10); Bálint 1989, 73; Pálóczi-Horváth 1989, 21 (fig. 12); Garustovich, Ivanov 2001, 88. For more in general on the subject of the blunt weapons used by the steppe peoples: Świętosławski 1996, 37-39.

35 Pálóczi-Horváth 1989, 17 (fig. 6), 34 (fig. 19), 35.

351 Nagrodzka-Majchrzyk 1985, 109; Bisembaev 2003, 85 (he records three long knives, one of which was as long as $18 \mathrm{~cm}$. Their blades had a convex profile. The lack of a hilt-guard led the researcher to classify them as khanjalis)

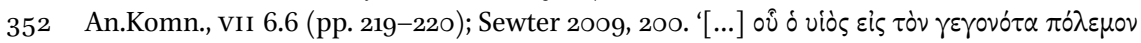

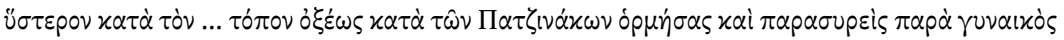

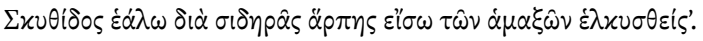


word $\dot{\eta} \ddot{\alpha} \rho \pi \eta$ can also mean 'sickle'353 or simply 'hook. ${ }^{354}$ Regardless of which of the proposed translations we consider more appropriate, it is quite difficult to explain what kind of weapon Anna Komnena is referring to here. Tryjarski assumes that the above-mentioned Migidenos' son could have been caught up in a lasso with an iron sickle at the end. ${ }^{355}$ However, his later fate seems to indicate that this 'innovation' was not meant so much for capturing the enemy, as for inflicting death. ${ }^{356}$ It also cannot be ruled out that the above account documented the use of some kind of improvized pole weapon, topped with a sickle or a hook. Giovanni da Pian del Carpine recalls that some heads of Mongolian spears were equipped with hooks that were used to pull the opponent off his horse. ${ }^{357}$ However, such a weapon is poorly attested archaeologically. In addition, it has thus far been discovered only on the eastern stretches of the Great Steppe. ${ }^{358}$ Therefore, the use of this kind of spear by a female 'Scythian' warrior seems unlikely.

Accounts on the use of armour are definitely the scarcest. On the basis of a passage from the chronicle of Michael Psellos, one could even conclude that the Pechenegs did not wear any armour at all:

They wear no breastplates, put on no greaves, and no helmets protect their heads. They carry no shields of any kind whatsoever, neither the long sort like those traditionally borne by Argives, nor the round shield, nor do they gird on swords. ${ }^{359}$

This statement, however, comes from an author who despite his broad education was not an expert in the art of war. His account can therefore not be regarded as a conclusive basis for determining whether the Pechenegs wore armour. Rather, the most probably wore leather armour and gambesons, which have not survived to our times due to the low durability of the material from

353 Cf. Polish and Russian translation of the Alexiad: Liubarskii 1965, 216; Jurewicz 1972, 18.

354 This meaning is assumed by Dieter Reinsch. Reinsch 1996, 251.

355 Tryjarski $1975^{a}, 5^{64}$.

356 Migidenos' son was beheaded, and his head was later bought from the Pechenegs by Emperor Alexios Komnenos. An.Komn., viI 6.6 (p. 220); Sewter 2009, 200.

357 di Carpine, vi 9 (p. 278). 'Aliqui eorum lanceas habent, et in colo ferri lancee habent unum uncum, cum quo detrahunt hominem de sella si possunt.'

$35^{8}$ Świętosławski 1996, 36-37, tab. XIII (fig. 5-7, p. 95).

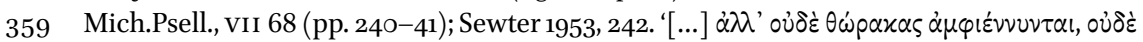

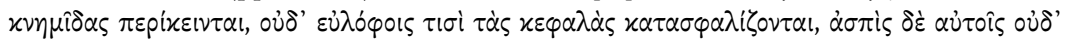

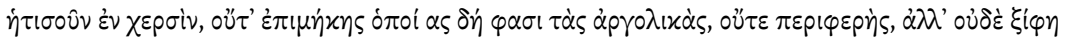

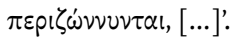


which they were made. ${ }^{360}$ Archaeological research confirms that the nomads of Black Sea steppe used mail. ${ }^{361}$ Items of this kind are mostly dated to the 12th century and later. Therefore, they could have been used by those Pechenegs who became part of the Cherni Klobuci tribal union. The origin of mail is not nomadic. Its invention is attributed today to the Celts. ${ }^{362}$ In the Middle Ages, it was commonly used in Rus' and from there, probably found its way to the Black Sea steppe. It cannot be ruled out that the Pechenegs may have worn other types of protective garments that were more sophisticated than leather armour. At two burial sites in western Kazakhstan (at Bek-Bike and the Shalkar III cemetery), dated roughly to between the 8th and the 11th centuries, elements of lamellar armour were discovered, while another burial site (Karas I) contained the remains of chain mail. ${ }^{363}$ The graves at those sites were definitely the resting places of members of the highest social strata. ${ }^{364}$ Unfortunately, it is impossible to define their ethnic identity precisely. In the case of the earlier dating (8th century), it may have been the Pechenegs, though in the case of the later time period (10th-11th century) it was most likely the Uzes. ${ }^{365}$ The elite nature of armour was the cause of its scarcity in the 1oth and 11th centuries, which in turn resulted in their rarely being attested in archaeological data. ${ }^{366}$

Elements of the horse tack and riding equipment, however, are very commonly found in burial inventories. The most frequently discovered items include girth buckles, bits and stirrups. ${ }^{367}$ The Pechenegs, like most nomads, probably used tall saddles with pommels and stirrups on flaps. The latter made it easier to get on the horse and made it possible to ride the horse over long distances. Moreover, with properly shaped pommels such a saddle allowed a horseman to shoot his bow to the rear and to strike his enemies with his sabre. Pecheneg stirrups had a characteristic round shape, looped stirrup leather,

\footnotetext{
360 Pálóczi-Horváth 1989, 18.

361 Dąbrowska 1965, 140-141; Pletneva 1973, 95; Nagrodzka-Majchrzyk 1985, 111; Świętosławski 2006, 114-116. For more in general on the armour used by nomads: Świętosławski 1996, 16-29; Tryjarski 1984, 173-184.

362 Świętosławski 1996, 21.

363 Bisembaev 2003, 85-86.

364 In addition to plate armour, sabres were also found on both sites; in the burial sites at the Shalkar III cemetery, a silver mask was also discovered. Bisembaev 2003, 86 .

365 Much like findings from the north-western Black Sea steppe. Dobroliubskii 1986, 5o. The researcher mentions the presence of the remains of chainmail in nomadic burial sites dating back to late-gth to late-11th centuries. However, such a wide range of dates makes it difficult to determine the ethnic origin of the find. They could equally well be attributed to the Pechenegs, the Uzes or the Cumans.

366 The problem of armour was similar in the Cherni Klobuci: Nagrodzka-Majchrzyk 1985, 111.

367 Pletneva 1958, 156; 1981, 214-215.
} 
and a semicircular footrest. Artefacts of this kind are present on the Black Sea steppe in the 1oth century, while in the following century they practically cease to be found, which seems to indicate their close connection with the Pechenegs. ${ }^{368}$ Equally typical of these nomads was their supposed use of a snaffle bit with rigid mouth pieces. ${ }^{369}$ Girth buckles took a variety of shapes. The Pechenegs usually used oval ones slightly curved along the longer side. ${ }^{370}$ Rarer finds include saddle decorations and strap separators. One burial inventory discovered in Crimea attributed to the Pechenegs contained strap dividers and fittings, clasps and appliqué work. All of these items were gold-plated and decorated. ${ }^{371}$ The steppe people did not tend to use spurs. To direct their horses, they used leather whips, the handles of which are found in nomadic graves. These were usually made of bone, bronze, and iron. The Pechenegs' whips are known to have had cylindrical or ovate hilts that were made of bone and had a curved ending. ${ }^{372}$

The above description of the Pecheneg warriors' equipment seems to indicate that, despite some deficiencies, it was quite versatile. A well-armed Pecheneg warrior could effectively inflict losses on enemy forces both at a distance and in melee. Of course, the manner in which soldiers were armed varied greatly. Well-equipped horsemen were probably a minority, recruited from among the tribal elites. Judging from Arab sources, the Pechenegs could not complain about a lack of military equipment. Although this written information concerned the 9 th century, there is nothing to indicate that this state of affairs changed after the Pechenegs moved onto the Black Sea steppe. The wide range of weapons in the steppe-dwellers' arsenal, as described by Muslim authors, stood out in comparison with those of neighbouring nomadic peoples; however, the weaponry of the heavily armed Byzantine horsemen was most likely superior in quality to that of a mounted steppe-dweller. A Pecheneg warrior's light, leather armour simply did not provide adequate protection in

368 Pletneva 1958, 156; 1981, 214; 199o, 50-51; Bálint 1989, 72; Pálóczi-Horváth 1989, 21 (fig. 11); Garustovich, Ivanov 2001, 83-84; Bisembaev 2003, 81-82.

369 Pletneva 1958, 156; 1981, 215; 1990, 48-49; Garustovich, Ivanov 2001, 85-86; Bisembaev 2003, 82. For a critical stance: Spinei 2009, 294-295.

370 Pletneva 1981, 214-215; 1990, 51-52.

371 Pálóczi-Horváth 1989, 22, 23 (fig. 13, 14); Chardaev 1991, 257, 338 (tab. 19o). The Crimean archaeological site (Saraili-Kiyat) shows analogies with the findings from the Lower Dnieper (Kamenka, Kotovka, Staro-Shvedskoie, Gorozheno), and from the village of Gaievka. This last statement, based on coins featuring Constantine viII (1025-1028), should be dated to the second quarter of the 11th century, which, given its location (Voronezh area, over the middle Don) means they should be assigned to the Uzes.

372 Pletneva 1981, 214-215. 
close combat, and for this reason above all they could not effectively fight a heavily armoured Byzantine soldier. It must be noted, however, considering the course of events at Walandar, that the outcome of such a confrontation was not always a foregone conclusion. Thanks to its lighter armour, the nomad army possessed a degree of mobility that was superior to that of either the Byzantine or Rus' cavalry. The high value of certain elements of the Pechenegs' military equipment is evidenced by the fact that it was gradually appropriated by the armies of neighbouring countries, mainly Kievan Rus. The items which most eagerly adopted and widely disseminated were the nomads' bows and sabres. The latter became a permanently fixture in the Rus' armoury in the 12th century. Later, as an element of the process of adapting to the steppe peoples' military methods, these items began to be produced locally. ${ }^{373}$ Some elements of the nomads' horse tack, especially their stirrups, which were important for proper use of a sabre, also enjoyed wide popularity. ${ }^{374}$

In order to fully appreciate the merits of the Pechenegs' military expertise and performance, we need to examine those aspects that go beyond the categories of tactics, weaponry, and organizational military structure, and thus those features that stemmed from their specific temperament and way of life. Michael Psellos addressed these issues quite eloquently:

In one mass, close-packed and pell-mell, fortified by sheer desperation, they emit loud war-cries, and so fall upon their adversaries. If they succeed in pushing them back, they dash against them in solid blocks, like towers, pursuing and slaying without mercy.375

He continues:

When they are thirsty, if they find water, either from spring or in the streams, they at once throw themselves down into it and gulp it up; if there is no water, each man dismounts from his horse, opens its veins with a knife, and drinks the blood. So they quench their thirst by substituting blood for water. After that they cut up the fattest of the horses, set fire to whatever wood they find ready to hand, and having slightly

373 Szymański 1973, 126-127.

374 Szymański 1973, 128.

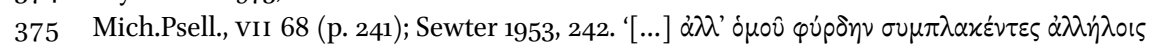

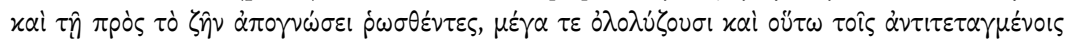

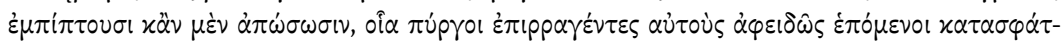

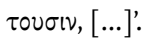


warmed the chopped limbs of the horse there on the spot, they gorge themselves on the meat, blood and all. The refreshment over, they hurry back to their primitive huts and lurk, like snakes in the deep gullies and precipitous cliffs which serve as their walls. ${ }^{376}$

Psellos' account is characterized by a clear tendency to exaggerate. The author sees cruelty, ferocity, primitivism, and a disregard for life as the sole source of the Pechenegs' military successes. ${ }^{377}$ He does not refer to other aspects of their military; in fact, he appears to suggest that their military has no tactics or organizational structure, and that the only weapons it uses are spears. However, despite its biased nature, his account confirms that as steppe dwellers, the Pechenegs possessed a number of qualities that, together with their approach to the art of war, gave them an advantage in a confrontation with an opponent. Their courage, endurance and ruthlessness were products of the harsh living conditions on the steppe. The loss of herds, pastures or access to sources of water was tantamount to depriving them of the right to exist, so a potential rival interested in seizing these assets from them was considered be a mortal enemy that had to be destroyed at all costs. A similar state of affairs led to the creation of a rather specific 'nomadic' means of fighting, the strategic goal of which was the ruthless elimination of the enemy. Demonstrating benevolence after a victory was considered a dangerous move because it could have led to a revival of the enemy's military power and thus to a renewed threat. 378

All of the factors described above made the Pechenegs a dangerous opponent, but their military was not without its flaws, revealed when the Pechenegs tried to conquer a well-fortified area. From The Tale of the Bygone Years we learn about a number of attempts to occupy Kiev and other fortified Rus' cities. However, all of them, from the first, dated 968, to the last, which took place in 1036, were unsuccessful. ${ }^{379}$ An exception in this string of disasters was provided by al-Mas'ūdī, who described the taking of the Byzantine fortress Walandar. It is also known that the invasions of the Pechenegs in the 103os led to the

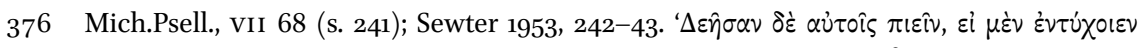

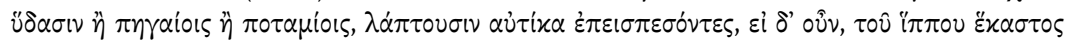

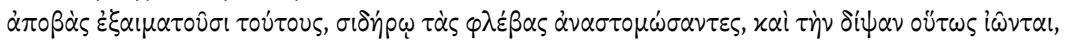

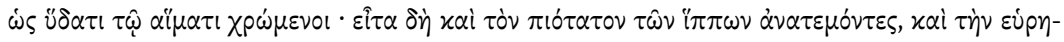

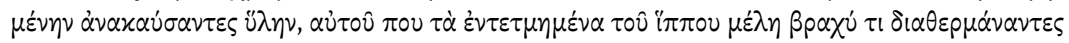

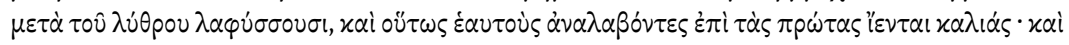

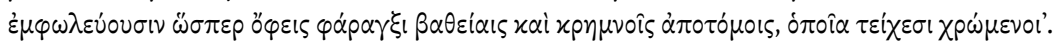

377 Cf. footnote 5 .

378 For a most striking example of such reasoning: Io.Scyl., 459; Wortley 2010, 43 O.

379 PVL 1, AM 6476 (968), col. 65-67; AM 6505 (997), col. 127-129; AM 6544 (1036), col. 150-151; Thietmar, viII 32 (p. 530). 
destruction of the system of defences on the Danube border of Byzantium. A number of forts guarding this frontier were almost completely destroyed during this period. Anna Komnena writes that during the war of 1087-1091, the Pechenegs managed to take fortified Byzantine cities several times (e.g. Philippopolis). ${ }^{380}$ We do not know what led to the successes of these assaults. Neither the Alexiad nor Meadows of Gold provides any information of value for determining how these strongholds were taken. Mas'ūdī only states that the allied nomadic forces used the bodies of those who had fallen in previous fighting to scale the walls of Walandar. ${ }^{381}$ This rather macabre information, however, is not deserving of consideration. It is possible that this success was achieved through the help of ethnically foreign experts in the art of siege. ${ }^{382}$ We also cannot reject the possibility that these strongholds were taken by siege, but with the help of some ploy. According to an account dated 997 in The Russian Primary Chronicle, when faced with strong resistance by defenders, the Pechenegs were able to engage in advanced tactics. During their siege of Belgorod Kievski, they did not allow the inhabitants to leave the town, hoping that a lack of supplies would force them to surrender. However, this time, too, they were unsuccessful. ${ }^{383}$ It should be stated that in general, large, wellstocked fortresses were rarely taken by the Pechenegs.

The weaknesses described above were exploited by their opponents, in particular the Kievan Rus'. We know that in the late 980 s, when tensions between these two neighbours had reached their peak, Vladimir the Great began construction of a complex system of fortifications to protect the eastern and southern borders of his country from invasions by Pechenegs. According to information contained in The Primary Russian Chronicle, such strongholds were built on the Desna, Oster, Trubezh, Sula, and Stugna. ${ }^{384}$ It is also possible that during the same period a significant part of the fortifications that came to be called the 'Serpent's Wall' were constructed or strengthened. They ran along

38 o An.Komn., viI 6.4 (p. 219); Sewter 2009, 200.

381 An equally macabre, but much more reliable example can be found in Roger of Torre Maggiore's Carmen miserabile. The monk describes the conquest of the fortified village of Pereg, located between the cities of Arad and Csánad, during the Mongolian invasion in 1241. During the siege, first Hungarian prisoners-of-war, then Rus' and 'Ishmaelites' (possibly Muslims from Volga Bulgaria, Alania, Khwārazm and the Black Sea-Caspian steppe) stormed the village as human shields, followed by the Cumans, who were forced to fight alongside the Mongols. According to the Italian monk, the corpses of the dead were used to fill the moat surrounding Pereg. It is possible that an analogous method of siege warfare was used by the Pechenegs and the Magyars who supported them at Walandar.

382 Cf. Świętosławski 1996, 45-47.

383 PVL 1, AM 6505 (997), col. 127-129.

384 PVL 1, AM 6496 (988), col. 121. 
rivers (Stugna, Irpin', Teterev, Dnieper, Sula), which provided a kind of natural moat for them. The embankments were not particularly high (estimates range from 3.5-4 to 6-8 metres), but they were often preceded by a 12-metrewide trench. There may have been a palisade along the top of the fortifications. Combined with a series of fortified settlements, they formed a rather strong defensive barrier against attacks by the Pechenegs, hindering access to Kiev's foreground and making it practically impossible to carry out a sudden attack on the capital city. 385

Rus' chronicles and the majority of scholars assume that these fortifications were built in response to aggression by the Pechenegs. It is difficult to question such an interpretation, but it is worth remembering that the steppe people's raids recorded in chronicles, which clearly intensified in the late 980 , could have been a response to the incremental southward expansion of Rus' that began under the reign of Sviatoslav and then resumed under Vladimir. This clearly harmed the interests of the Pechenegs, disrupting their trade relations. ${ }^{386}$ It is also worth noting that the construction of the Serpent's Wall and the accompanying fortified settlements resulted in a clear shift in the border of the Rus' state to the south, in some places by more than $100 \mathrm{~km}$, i.e., deep into the area of the forest steppe, which was most likely considered by the Pechenegs to be their natural domain. Given this situation, their desire to reclaim these lost territories seems understandable. The Pechenegs, were unable to do so, but despite this fact, at the turn of the 1oth and 11th centuries they managed to threaten Kiev several times. Like most steppe peoples, they were able to carry out violent attacks designed to evoke terror. This ability made them highly dangerous and difficult to control, but apart from the

385 Bruno, 99. Cf. Kowalczyk 1969, 141-181; Kuchera 1987, [Rev. Kowalczyk 1989, 180-187: the researcher questions a number of Kuchera's findings, including the chronology of the construction of many fortifications, usually dated by the Ukrainian archaeologist to the reigns of Vladimir or Yaroslav the Wise]; Hensel 1987, 500-5o1; Szymanski 1973, 130-131; Franklin, Shepard 1996, 170-172; Morgunov 2010, 64-65. In the light of the above observations, Hansgerd Göckenjan proposed a hypothesis, which involves the existence of a system of fortifications on the border between Patzinacia and the Danube Bulgarian State, seems quite surprising. The basis for his interpretation is the information contained in Chapter 37 of De administrando imperio on six abandoned fortresses ( $₹ \eta \mu \delta$ ó $\alpha \sigma \tau p \alpha$ ) located at fords on the Dniester River. The etymological analysis of the forts' names carried out by Josef Németh is supposed to provide additional justification for this hypothesis. Németh's findings however have been challenged. Moreover, it is difficult to explain why the nomads would have created a system of fortifications along the border with Bulgaria. DAI, XXXVII 58-66 (p. 168/9). Marquart 19o3, 196; Németh 1930, 33-34; Menges 1944-45, 271-273; Göckenjan 1972, 92-93.

386 Cf. second part of this chapter. 
destruction and havoc they caused, these attacks did not generally result in further-reaching consequences. This was due to the Pechenegs' specific political structure, which allowed them to act jointly against external threats, but prevented effective external expansion. Deprived of a clear political centre, the Pechenegs were not only incapable of conquering neighbouring territories, but also of effectively defending their own, as the example of their confrontation with Rus' clearly shows. The efficient fortification and colonization of Kiev's foreground by the Rurikids resulted, as noted earlier, in the nomads being deprived of a large portion of their lands, which they were ultimately unable to regain.

Owing to their military capabilities, the Pechenegs were able, as depicted by Constantine Porphyrogenitus, to threaten neighbouring states and ethne, which especially in the mid-1oth century, was the source of their political significance. However, their military actions were usually instinctive, dictated by the need to defend their territory against aggression by other steppe ethne (e.g., the Uzes) or the desire for retaliation or the acquisition of wealth. In the early 11th century, the Pechenegs began to lose their military advantage. Once Byzantine and Rus' commanders developed an understanding of the merits of the steppe people's tactics, they began to adopt them themselves. ${ }^{387}$ The role of an intermediary in this transfer of knowledge could have been played by auxiliary units comprised of nomads who had taken up service under the Rus' prince or the Byzantine basileus. ${ }^{388}$ In order to adapt to fighting against the Pechenegs, cavalry units and some typical elements of the nomads' military equipment become commonplace among the Rus' forces in the last decades of the 1oth century. 389 Thanks to these borrowings and the construction of fortifications, the rulers of Rus' managed initially to even the odds in battles with their troublesome neighbours, and with time, to take the initiative, which resulted in their final victory over the Pechenegs in $1036 .{ }^{390}$

\subsection{The Pechenegs' Ethnic Identity and Value System}

Ethnicity is a subjective and situational phenomenon. It involves the choice of identity, often made in conditions of a specific experience of contact with 'the other'. The creation of ethnic identity consists both in accepting values

387 Pletneva 1958, 198.

388 Cf. chapters 6 and 7 of the present book.

389 Szymański 1973, 130.

39 PVL 1, AM 6544 (1036), col. 150-151. 
considered by a particular community to be constitutive of it, and in rejecting values held by strangers as irrelevant or even threatening. We are therefore dealing with a process which determines the existence of a particular community. Identity is created and reconstructed in each new generation, which experts call 'ethnic practice'. ${ }^{391}$ The transfer of identity from generation to generation results in the emergence of a tradition whose components can include customs, legal norms, religious beliefs, language, lifestyle, and elements of clothing and appearance. ${ }^{392}$ The choice and meaning of these elements in the process of creating the identity of a given ethnos is highly subjective and depends on the specific historical situation and needs of the community in question. Certain elements of tradition can seem to lose their meaning in one generation, only to be revived in the next. Researchers of nomadic peoples talk about layers of tradition which 'remain in reserve', i.e., elements seemingly forgotten or excluded from everyday social practice, but which can suddenly be revived and once again become a basis of identity. ${ }^{393}$

While ethnicity is a subjective phenomenon and one based on individual and collective choices, it is not an arbitrary creation. It is founded on a set of cultural models and values which have been adopted or created by a particular community over the course of its history. ${ }^{394}$ It is, of course, a truism to say that not all members of a particular ethnos identify with it to the same degree. In fact, quite often - especially when we obtain information from a description provided by an outside observer - we find certain collective traits being assigned to a given ethnic organism. Herodotus considered all those who remained under the authority of the Royal Scythians to be Scythians. ${ }^{395}$ Sima Qian used a similar criterion in his characterization of the Xiongnu. ${ }^{396}$ However, the example of European historian is much more significant, because he did so being aware of the radical cultural differences between various Scythian groups. Since the publication of Reinhard Wenskus' fundamental study Stammesbildung und Verfassung, it has been understood that the concept of a uniform origin of all the individual members of a given community

391 Geary 2012, 32; Pohl 2008, 276-277; 2008a, 19-20.

392 Zientara 1985, 30-32; Geary 2012, 22-25; 2012a, 5 o.

393 The concept of ideology 'in reserve' was introduced by Philip Carl Salzman, who applies it to situations where an ideology outwardly accepted and professed by a particular community is not observed in everyday practice. According to him, this can be explained by the desire to maintain a cultural alternative that may be needed when the external conditions of the life of the community change. Salzman 1978, 618-637; 1980, 1-19.

394 Geary 2012, 31

395 Paroń 2007, 55-57.

396 Paroń 2012, 94. 
is entirely fictional, since in the course of history its composition has been complemented by ethnically and anthropologically diverse collectivities. 397 Given this situation, it is natural for degrees of identification to differ within groups. Most researchers emphasize the importance of an ethnic core, which is primarily responsible for storing and promoting the traditions that integrate the entire ethnos. ${ }^{398}$ Alongside this elite group, there is always a majority who experience a more instinctive and situational sense of ethnicity. One must also assume the presence of peripheral groups, whose relations with a particular ethnos were based solely on violence, and who are therefore willing, if circumstances are favourable, to break away from the community. At its core are elites who express aristocratic tendencies towards the rest of the ethnos. ${ }^{399}$ Similar phenomena are also visible in nomadic communities. An example of this is the division into 'white bone' and 'black bone', the latter applying to conquered tribes. ${ }^{400}$

In the centralized model described above, the formation of an ethnos is perceived as the incorporation of particular groups into a strong centre, represented by a charismatic leader or clan, who in order to justify their domination, create and nurture an orthodox version of the ethnic tradition. Ethnogenesis, however, can take a more complicated route, making it more difficult to describe and understand. An example of this is the origins of the Slavs, which usually lack a clear centre of integration. The creation of community traditions in this case was a dispersed process, difficult for one group to monopolize. ${ }^{401}$

It seems that in the case of the Pecheneg, the latter model provides a more accurate picture. The presence of three tribes called 'Kangar' (Kórrap) with a segmented political structure was confirmed in De administrando imperio. Those who enjoyed the aforementioned designation were considered

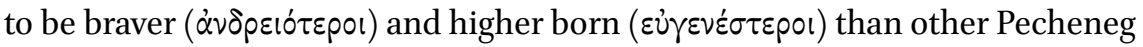
tribes. ${ }^{402}$ Elsewhere Constantine VII adds that in the earlier period of their

397 Wenskus 1961.

398 Geary 2012, 27; Wolfram 1990, 111-112; 1993, 27-39.

399 F.G. Schultheiss identified and defined two types of distinctiveness experienced by individual nations: national sentiment (Nationalgefühl), more common, but primary and instinctive, and national consciousness (Nationalbewusstsein), strongly developed, and based on a conscious understanding of what distinguishes a given (my) nation from others and of the source of this distinctiveness. This applies to only a small group and involves treating the factors determining its separateness as a common good. A very similar model, based on Stanisław Ossowski's sociology, is presented by Aleksander Gieysztor. (1972, 20-21). Cf. Geary 2012a, 46-47; Pohl 2008a, 19.

400 Moszyński 1996, 29.

401 Geary 2012a, 47-48.

402 DAI, XXXVII 68-71 (p. 170/1). 
history all Pechenegs were called 'Kangar.'403 This group should therefore be seen as the core of the ethnos, which were integrated around the 'Braver.404 It is noteworthy, however, that John Skylitzes does not know anything about them in the mid-11th century. He traces the origins of the Pechenegs back to the Royal Scythians, thus replacing the steppe-dwellers' native genealogy with a Byzantine 'systematics' of barbaric ethne, based on the traditions of ancient Greek ethnography. ${ }^{405}$ The tradition of which the 'Kangar' tribes were holding at that time may have either lost its importance or been significantly modified with the changes which affected the political organization of the Pechenegs during the century between the mid-1oth and mid-11th centuries. ${ }^{406}$ Skylitzes notes, however, that each of the 13 Pechenegs geneai had its own name, inherited from its ancestor and proto-parent. ${ }^{407}$ This information clearly indicates that individual tribes nurtured their own genealogy, although it is difficult to say whether this was legendary in nature. Constantine Porphyrogenitus knows the names of the heads of eight Pechenegs tribes who were in charge of them at the time when the whole ethnos was expelled from its former homeland east of the Volga. ${ }^{408}$ This event had taken place 55 years before the relevant chapters of De administrando imperio were written. This information had to come from the steppe people themselves, more specifically, from their elites, for whom a knowledge of these ancestors provided legitimacy for their social position.

Traditions concerning origins were thus cultivated within individual tribes. We do not know anything about an analogous phenomenon that would have concerned the whole ethnos. Meanwhile, legends about the common origin of a given people, including their genealogy or the genealogy of the family ruling over them, are common among steppe societies. From Herodotus we have several versions of the Scythian origines. ${ }^{409}$ The Blue Turks (Tūjué) were said to have originated from the Ashina clan, which was said to be part of the Xiongnu people. The Ashina are said to have descended from a 10-year-old, mutilated prince (his feet were cut off), who was the sole survivor of a bloody raid that wiped out his village. He was rescued by a she-wolf, who fed the boy with meat, and when he grew up, had carnal relations with him. Their progeny

\footnotetext{
403 DAI, XXXVIII 2O, 25 (p. 170/1).

404 Cf. Chapter 3 of the present book.

405 Io.Scyl., 455 (v. 32-34); Wortley 2010, 426.

406 Cf. the first part of this chapter.

407 Io.Scyl., 455 (v. 34-37); Wortley 2010, 426.

408 DAI, XXXVII 19-24 (p. 166/7).

409 Hdt., IV 5-16 (pp. 2O2-217).
} 
gave rise to the Turks. ${ }^{410}$ One of the rulers of the Wusen, a people conquered by the Xiongnu, owed his salvation to a raven and a wolf, because these animals fed him as a child when he was hiding in the desert from his enemies. ${ }^{411}$ According to The Secret History of the Mongols, the progenitors of the Temujin family were quu maral (fallow doe) and börte činō (blue-grey wolf). ${ }^{412}$ The Turkmens believe that their common ancestor was Oghuz Khan. In a series of legends describing his achievements, there are also stories about the progenitors of other Turkic ethne, including the Uyghurs, Kipchaks, and Karluks. ${ }^{413}$

This type of tradition most likely also existed among the Pechenegs, although due to a lack of data we do not know the details of its content. It was most likely cultivated mainly by individual tribes. Due to the necessity of frequent migration, a knowledge of the genealogy of one's ancestors and their achievements became one of the basic factors that made it possible to create and preserve one's identity. True or fictitious stories about the achievements of prominent ancestors also regulated the behaviour of contemporaries, constituting a kind of supplement to the common law. ${ }^{414}$

The memory of ancestors was also strengthened by certain aspects of religious beliefs, especially the cult of ancestors, which is a common phenomenon among nomads. According to ethnologists of religion, apart from the cults of Heaven, Earth, and various spirits of the steppe, it is one of the basic elements of the nomadic religious system. ${ }^{415}$ Some Turkic ethne worshiped their ancestors as heroes, and thus as persons of merit to the entire community. ${ }^{416}$ It is also known that in Inner Asia there was a custom of erecting stone statues in honour of outstanding leaders. This custom was carried over to the Black Sea steppe, where they are known as stone 'babas'.417 These statues date back to the mid-11th century at the earliest, for which reason they are usually attributed

\footnotetext{
410 Liu Mau-Tsai 1958, 5-6. Cf. Sinor 1982, 223-237; Tryjarski 1995, 6o-63.

411 Watson 1961, 271-272. Cf. Sinor 1982, 237-240; Tryjarski 1995, 65-66.

412 Rachewiltz 2004, I, 1. Cf. Sinor 1982, 240-246.

413 Rašid ad-Din, I 2, 76-91; Abu-l-Gazi, 40-43.

414 Moszyński 1996, 27; Tryjarski 1993, 215, 226.

415 Szyjewski 2001, 426.

416 Gumilev 1993, 82.

417 The purpose of these stone statues is not entirely clear. Some researchers assume that they are not representations of prominent deceased persons, but of the enemies they killed. The latter function was supposed to dominate in the eastern part of the Great Steppe. Sometimes, however, these 'stone babas' are distinguished from stone balbals. The latter are supposed to represent enemies who were killed by the deceased, while the former are statues of prominent persons. Cf. Tryjarski 1991, 294-305.
} 
to the Cumans. Stone statues may have also been made by earlier nomadic peoples, including the Pechenegs. ${ }^{418}$

A spectacular manifestation of this people's distinctiveness was noted by Constantine Porphyrogenitus. The emperor described the behaviour of a group of Pechenegs, which at the end of the gth century separated from its ethnos:

At the time when the Pechenegs were expelled from their country, some of them of their own will and personal decision stayed behind there and united with the so-called Uzes, and even to this day they live among them, and wear such distinguishing marks as separate them off and betray their origin and how it came about that they were split off from their own folk: for their tunics are short, reaching to the knee, and their sleeves are cut off at the shoulder, whereby, you see, they indicate that they have been cut off from their own folk and those of their race. ${ }^{419}$

This story, which probably came from the Pechenegs themselves, sounds rather anecdotal, but there is no reason to question its credibility. The manifestation of ethnic identity through elements of clothing is a widely confirmed phenomenon in the Eurasian steppe. Clothing was a form of everyday 'ethnic practice' because it allowed people to clearly differentiate themselves from their surroundings, and, as some apparel scholars claim, it may have served as a kind of identity card. ${ }^{420}$ The presence of some sort of Pecheneg grouping within the Uze community, or rather on its periphery, is confirmed by a passage from Ahmad ibn Fadlan's Risala. ${ }^{421}$ The manifestation of distinctiveness described by Constantine Porphyrogenitus is also a proof of a strong ethnic bond among the Pechenegs. Nomads who were detached from their native ethnos must have taken pride in their origins, since they decided to build their identity on

418 Pletneva 1974; 1990a, 100; Daszkiewicz, Tryjarski 1982, 195-196; Tryjarski 1991, 300; Waklinow 1984, 158 (the author attributes to the Pechenegs two stone figures depicting a woman and a man, discovered in Bulgaria, near the village of Endzhe, near Shumen); Fiedler 2013, 253-26o.

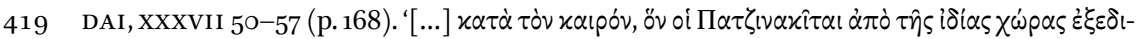

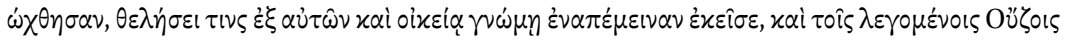

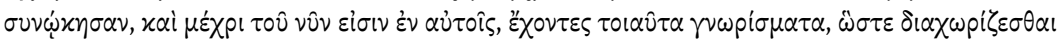

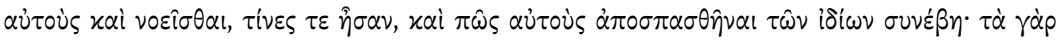

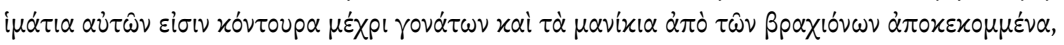

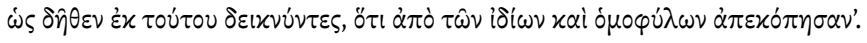

420 Szymański 1979, 95; Iatsenko 2012, 111-112.

421 ibn Fadlan: ibn Fadlan, 212-215; Zeki Validi Togan 1939, 33; Kovalevskii 1956, 13o; Frye $2005,42$. 
it in their new living situation and demonstrate the fact they were separated from their native community.

The above-mentioned fragment of De administrando imperio also points to the circumstances in which one's sense of ethnic identity manifests itself: contact with outsiders. In such a situation, elements of one's native culture lifestyle, common law, beliefs, and language - which in everyday conditions might go unnoticed, suddenly become the centre of a community's identity. The relations between nomads and agricultural communities, it can be assumed, created the necessary conditions for the occurrence of a radical experience of otherness, which was probably accompanied by an intensive re-evaluation of one's own identity.

Differences in lifestyles were certainly the first to be noticed. A nomadic lifestyle was, from the perspective of settled communities, the main feature that distinguished and defined the world of steppe people; for the latter it was the main facet of their identity and a guarantee of independence. A nomadic or semi-nomadic way of life, which involved travelling across vast spaces, allowed a nomad to experience unrestricted freedom. The type of economy that was the main source of income for the steppe people did not require much physical effort and was not very absorbing. According to some researchers, such a state of affairs could have been the cause of the 'laziness' often observed by outsiders in nomads. ${ }^{422}$ What is certain, however, is that this way of life, as a source of true freedom, filled them with pride. Compared to this existence, the life of a farmer bound to the land, and forced to perform unchanging and difficult labour, not only did not appeal to nomads, but even filled them with contempt, as an existence worthy only of a slave. Those who cultivated the land had to break their backs and struggle with everyday hardships which, in contrast to the sweet idleness of nomads, seemed to embody the agrarian struggle for survival. The steppe dwellers also considered their way of life to be fully in harmony with nature, as they did not alter the space in which they lived. The Mongols used to say that their land had skin (körösü), as opposed to the ploughed, or even 'skinned' land of farmers (körösü-ugei). ${ }^{423}$ Agrarian societies seemed to have the exact opposite view, according to which only by cultivating the land was a special bond formed between it and people. ${ }^{424}$ The natural state desired by steppe people implied that the land belonged to nobody because nobody worked on it. This sometimes led agricultural communities to occupy pastures, abandoned for some time by nomads, which in turn led to

422 Moszyński 1996, 26-27; Tryjarski 1975a, 528.

423 Jagchid, Hayer 1979, 310; Jagchid, Symons 1989, 175-176.

424 Nowicka 2001, 327; Modzelewski 2004, 259-263. 
conflicts. ${ }^{425}$ A nomadic way of life was also perceived as a combination of a state of temporary idleness, or outright laziness, with a state of military activity. The latter was supposedly impossible for hard-working farmers, which made them practically defenceless.

The set of beliefs outlined above must have given birth to aristocratic tendencies among the nomads. They believed that settled communities, deprived of freedom and unable to defend it, were by nature predestined to recognize the power of the nomads and satisfy their needs. ${ }^{426}$ This way of thinking is observed e.g., in the Royal Scythians ${ }^{427}$ and the Avars. ${ }^{428}$ It seems, however, that the stereotype of the farmer-slave may have existed in a more or less developed form in the mentality of most nomadic ethne, among which the Pechenegs would have been no exception. We can recall the account by John Skylitzes describing the efforts of Constantine Ix Monomachos to ensure that the members of the Pechenegs' ethnos who settled in the thema of Bulgaria would engage in agricultural activity. However, at the first opportunity that arose, they organized a rebellion and abandoned the farming they had been forced to perform. ${ }^{429}$ The Byzantine ruler did not realize that from the perspective of a nomadic society, the abandonment of the old way of life and living off the land was understood as a type of degradation, a transition from being a free man to a state of slavery. As a consequence, it had to lead to a loss of identity.

The nomadic way of life was important for yet another reason, one that was realized by more perceptive leaders of the steppe people and by keener outside observers. Nomadism was a guarantee of the independence of nomadic political organisms, especially when they entered into relations with powerful agricultural states. Only as mobile riders could they stand up to much richer and more numerous settlements. Herodotus understood this fact, ${ }^{430}$ and so did his Chinese counterpart Sima Qian. The latter recognized the Chinese renegade Zhonghang Yue as the one who discovered the importance of nomadism and a culture based on it as a guarantee of the Xiongnu's independence from China. ${ }^{431}$ The Turkic statesman Tonyukuk, an advisor to Bilge Khan (716-734),

\footnotetext{
425 Noonan 1992, 303.

426 Moszyński 1996, 30, 32; Kałużyński 1970, 9.

427 Herodotus states that the Royal Scythians considered the rest of the Scythians to be their slaves, including the Scythian-tillers and Scythian-farmers. Hdt., IV 20 (p. 220).

428 Szymański 1979, 42; Pohl 1988, 112-117.

429 Io.Scyl., 459 (v. 79-83), 461 (v. 27-42); Wortley 2010, 430, 431.

430 Hdt., IV 46 (p. 246), 120-144 (pp. 320-344).

431 Watson 1961, 170-175. Cf. Paroń 2012, 89-93.
} 
was aware of this fact as well. ${ }^{432}$ Genghis Khan himself was said to claim that the Mongols would be lost if they started living in clay houses. ${ }^{433}$ These examples seem to explain the stubbornness with which the Pechenegs tried to preserve their former way of life after they entered the Balkans.

Nomads, including the Pechenegs, strongly emphasized their independence when interacting with other peoples. Constantine Porphyrogenitus confirms that when Pechenegs performed services for the emperor or the inhabitants of Kherson, they always demanded payment for the completed task as free people. ${ }^{434}$ Similarly, an emperor's envoy sent to them on a mission had to pay remuneration for their help by offering gifts to the Pechenegs' representatives and their families. ${ }^{435}$ On such occasions, the Pechenegs were said to demand such rare luxury items that Constantine was prompted to associate them with unrestrained greed. This tendency, though often described in a caricatured manner, seems to indicate the rather ambivalent attitude of the steppe-dwellers towards settled peoples. Yet, while they despised their way of life and occupations, nomads often desired or were simply forced to obtain the goods produced by farmers. External symbols of wealth, luxury, and comfort that were abundant in highly developed civilizations, fascinated the steppedwellers. This admiration unleashed a desire to acquire these riches, ones extremely scarce in the harsh conditions of steppe life, by any means available. This desire is reflected in written sources providing the earliest historically documented contacts between settled communities and nomads.

Chinese chronicles speak of the great thirst for wealth found in the Xiongnu, as well as among the Blue Turks, who were equally dangerous to the Middle Kingdom. We learn from these sources that both ethne particularly valued silk. ${ }^{436}$ In characterizing the European Huns, Ammianus Marcellinus claimed that 'they burn with an infinite thirst for gold. ${ }^{437}$ The history of the Eastern Roman Empire's relations with Attila's empire confirms this account. Under the peace agreement of 447 , the court in Constantinople had to pledge to pay

\footnotetext{
432 Liu Mau-Tsai 1958, 172-173.

433 Jagchid, Hayer 1979, 19-20.

434 DAI, VI (p. 52/3).

435 DAI, VII 8-17 (p. 54/5). Cf. Paroń 2007a, 107-108.

436 At their peak, the Han people sent the Xiongnu nearly 95,00o metres of silk a year; in 553-572 the Zhou Dynasty sent the rulers of the Blue Turks 100,ooo bales of silk a year; The Uyghurs received 50o,ooo pieces of silk a year from the Tang. These are examples of the most spectacular tributes. Cf. Liu Mau-Tsai 1958, 395-396; Dąbrowski 1975, 34; Barfield 1992, 47, 64-67, 133, 154; Gumilev 1997, 33; 1992, 23; 1993, 146.
}

Amm.Marc., XXXI 2.11 (p. 386). 
the Huns an annual tribute of 2,10o pounds of gold. ${ }^{438}$ The Avars managed to extort literally tons of gold from the Byzantine Empire. ${ }^{439}$ Less powerful steppe ethne were not able to loot such huge amounts of gold, but they also eagerly coerced generous tribute. The Pechenegs were said to be 'shameless in their demands for generous gifts. 440

The above-mentioned tendencies among nomads were eagerly exploited by neighbouring states, which offered 'generous gifts' as a means for using the steppe peoples to achieve their political aims. Byzantine diplomacy in particular excelled in this. It is sufficient to recall the instructions of Emperor Constantine Porphyrogenitus, who emphasized that in order to win and maintain the friendship of the Pechenegs, a diplomatic agent had to be sent to them each year with sufficient gifts. ${ }^{441}$ From Rus' writings, we also know that the Pechenegs who participated in Igor's expedition against the Greeks were neutralized by Byzantine diplomats with the help of expensive gifts. ${ }^{42}$ There are many other similar examples concerning other ethne as well.

As noted earlier, the value of the 'gifts' received, or even coerced, by the Pechenegs did not match the great wealth of goods supplied to the steppe empires. The Xiongnu, Huns, Blue Turks, and Avars all received regular tributes, which may have been presented by the diplomats of neighbouring states as voluntary gifts or even manifestations of being in good graces. To stop paying, however, posed the risk of invasion, which the steppe people's leaders did not hide. It is also worth remembering that such a transfer of goods was possible within the framework of the special mutual relationship that existed between a steppe empire and a rich agricultural one. ${ }^{443}$ The Pechenegs did not constitute an imperial organism, so the 'gifts' they received were probably not as lavish and could have arrived in an irregular manner. Ahmad ibn Fadlan, an emissary of caliph al-Muqtadir (908-932) to the ruler of the Volga-Kama Bulgars, provides interesting comparative material. Before he reached the main destination of his diplomatic journey, he visited several elders of the Uzes. During a visit to Atrak, one of the elders, the Abbasid envoy presented

438 Prisc. 9.3 (p. 236). The amount mentioned in the treaty is the equivalent of $688 \mathrm{~kg}$ of gold. Cf. Hardt 2003, 97.

439 At the peak of this practice, the Avars were said to receive a tribute of 200,000 solidi, that is, over $900 \mathrm{~kg}$ of gold. According to various estimates, they were supposed to have coerced from Byzantium between 13.7 and 36.3 tons of gold. Pohl 1988, 178-185, 205-215; Hardt 2003, 99; 2004, 42-44, 175; Polek 2007, 243.

440 DAI, VII 9-10 (p. 54/5).

441 DAI, I $16-24$ (p. 48/9).

442 PVL 1, AM 9452 (944), col. 45-46.

443 Barfield 2001, 10-41; Paroń 2013, 224-233. 
gifts from the ambassador Nadhir al-Harami, who had sent 50 dinars, three mitqals of musk, [pieces of] red leather, two bolts of cloth from Merv, from which were cut two jackets, as well as a pair of boots of red leather, a coat of brocade, and five coats of silk. Al-Harami gave Atrak's wife a head shawl and a ring. ${ }^{444}$ These gifts were expensive, but far from the riches regularly received by the rulers of steppe empires. The fact that the donor was an ambassador and not the caliph himself does not change anything, because the gifts of al-Muqtadir to the 'king' of the Bulgars were not that glamorous either. ${ }^{445}$ The level of the material culture and political significance of the Pechenegs and the Uzes were most likely similar, so we can assume that the gifts received from their political partners were comparable in terms of both the types of goods (expensive fabrics, perfumes, precious metals) and their value. ${ }^{446}$

The gift-giving described by ibn Fadlan was part of a diplomatic rite which communicated the nature of the relations between political partners. For the steppe people, this was not just another opportunity to acquire wealth. Such an interpretation, though partly true, omits certain features of the steppe people's mentality, including that of the Pechenegs. Receiving expensive gifts was for them a matter of prestige; it meant they were being treated as free people. In diplomatic terms, for individual tribal chiefs who were reluctant to recognize any power above themselves, this meant that a potential ally was treating them as sovereign leaders. The goods acquired could also be redistributed within a particular community, which further strengthened the authority of its chief.

Giving gifts to the Pechenegs was most likely a means used by diplomats of all states who wanted to establish political ties with them or ensure their neutrality, although extant written sources seem to indicate that such a method was used mainly by the Byzantine Empire. Its diplomats were convinced that they were fully capable of exploiting the barbaric peoples' fascination with external manifestations of the empire's power. ${ }^{447}$ Indeed, the potential of Byzantium and its arsenal of methods for influencing neighbouring peoples developed over the centuries seem to justify this belief. Frequent complaints

444 Fadlan: ibn Fadlan, 210; Zeki Validi Togan 1939, 29; Kovalevskii 1956, 129; Frye 2005, 40. Some authors of translation of ibn Fadlan believe that in the case of the red leather, he simply meant leather which had been tanned (ibn Fadlan, 211; Kmietowicz, Lewicki $1985,96)$.

445 ibn Fadlan: ibn Fadlan, 216-218; Zeki Validi Togan 1939, 41; Kovalevskii 1956, 132; Frye 2005, 45. Ahmad ibn Fadlan writes about gifts consisting of fragrances, robes, and pearls.

446 Cf. DAI, vi (p. 52/3).

447 For more in general on Byzantine diplomacy, its rituals and Byzantine imperial doctrine: Treitinger 1938; Dölger 1953; Ohnsorge 1958; Ostrogorski 1973, 119-141; Shepard 1985, 233293; 1992, 41-71; Obolensky 1994, 1-22; Udal'tsova 1989, 241-275. 
by Byzantine authors about 'unfaithful and wicked' barbarians seem to indicate, however, that they sometimes remained resistant to the persuasion of imperial diplomats. Perhaps they were willing to accept the goods and concessions offered to them, but did not always behave as Constantinople wished. This observation also applies to the Pechenegs, as proved by the history of prince Sviatoslav Igorevich. The Steppe people did not agree to allow his safe return to Rus', despite the efforts of Emperor John I Tzimiskes. ${ }^{448}$

The political behaviour of the Pechenegs, which harmed the interests of neighbouring countries, was bound to cause irritation among their political elites, which in turn was reflected in written sources. Works by Byzantine authors, as well as Rus' chronicles, ${ }^{449}$ convey the theme of the godless nomad, i.e., an individual deprived of any religious sense that would constitute the basis for a coherent ethical system for governing the behaviour of individuals and communities. In fact, the looting and cruelty attributed to steppe people easily led one to the conclusion that they were committing such acts because they were not held back by a deity like the Christian God who would punish them for their crimes. This kind of reasoning is particularly visible in Michael Psellos' characterization of the Pechenegs:

Taken in the mass, this is a nation to be feared, and a treacherous one. Treaties of friendship exercise no restraining influence over these barbarians, and even oaths sworn over their sacrifices are not respected, for they reverence no deity at all, not to speak of God. To them all things are the result of chance, and death they believe to be the end of everything. For these reasons they make peace with great alacrity and then, when they find it necessary to resort to war, they at once violate the terms of their treaty. If you conquer them in war, they invoke a second treaty of friendship; if it is they who win the combat, they massacre some of their captives and hold a magnificent sale of the rest. For the rich prisoners they fix the price high, and if they fail to get ransom, they kill them. ${ }^{450}$

A few decades earlier, John Mauropous described the Pechenegs in a similar way. The metropolitan of Euchaita presented them as wild barbarians deprived of any basis for social order in the form of religion, law or knowledge. ${ }^{451}$ The

448 Io.Scyl., 309-310; Wortley 2010, 293; Io.Zon., XVII 3 (p. 535); Trapp 1986, 40. Cf. also Chapter 5 of the present book.

449 Chekin 1992, 9-28.

$45^{\circ}$ Mich.Psell., VII 69 (pp. 241-242); Sewter 1953, 243.

$45^{1}$ Io.Maur., $144\left(\S 9,196^{1}\right)$. 
motif of godlessness and the complete anomie of nomads, quite common in Byzantine historiography, often substituted for reflection on the principles governing steppe societies. Scholars reduced them to the status of hordes of wild animals, capable only of incomprehensible aggression. They were ignorant of any kind of order built on the foundations of law, custom and religion. This kind of perception has, of course, devastating consequences for our knowledge of nomadic customs. In the case of the Pechenegs, scientific reflection on the institutions fundamental to any community is almost entirely absent.

Meanwhile, customs and the laws derived from them are probably the most important elements of the traditions and identity of a particular ethnos. They are strongly connected with native beliefs and mythology, which are inseparable. All the categories listed here are of fundamental significance for the existence and continuation of an ethnic community. Reinhard Wenskus sees a people, above all, as a community sharing a common law. Adherence to it and to past beliefs allows one's identity to be preserved even if the group united by these customs loses the knowledge of its mother tongue as a result of remaining in a foreign environment. ${ }^{452}$ The great importance of customs was also understood by the Turkic peoples. It suffices to recall here an aphorism noted by the famous 11th-century encyclopaedist Mahmūd of Kashgar: 'The realm may be left behind but not custom' (ēl qalir törü qalmās). ${ }^{453}$

The word törü in Kāšgarî's quotation means 'custom', but also 'law', which seems to correspond closely to the Old Greek word nomos (vónos) and Latin mos. There is no indication, therefore, that nomadic communities were in principle anomic. This is also confirmed by information from less biased observers who stayed among the nomads. John of Pian de Carpini notes that 'Tatars' are honest towards each other, rarely resort to violence in their interactions, and in times of hunger share food and help one another. The Franciscan also emphasized the good manners of their women and very severe punishment for adultery. ${ }^{454}$ It is worth noting, however, Carpini's comment that these righteous customs of the 'Tatars' apply only within their community. The use of violence, killing, robbery or trickery was purportedly allowed when it was directed against strangers. ${ }^{455}$ A similar state of affairs, one which likewise assumed the observance of strict norms of coexistence within the native ethnos, but loosened them in relations with the outside world, could also have been found in the Pechenegs. The Byzantines most likely experienced this,

$45^{2}$ Wenskus 1961, 38-44; Zientara 1985, 31; Modzelewski 2004, 66, 67.

453 Al-Kāšgarī, I, 264. Cf. Tryjarski 1993, 215.

454 di Carpine, IV 2-3 (pp. 245-246).

455 di Carpine, III 8 (p. 240). 
especially since the latter half of the 11th century, which must have influenced their perception of these steppe-dwellers. They did not understand the world of nomads, which does not change the fact that the acts of aggression directed by the Pechenegs against the empire when they were officially part of it could not have been assessed positively by Byzantine historians and rhetoricians. ${ }^{456}$

Traditional beliefs, whose connection with common law has been indicated earlier, were also a very important tool for maintaining the distinctness of nomadic communities in their contacts with the outside world. The Danube Bulgars clearly contrasted their identity to that of the Byzantines based on religious differences. In an inscription dating back to the 820 attributed to the Khan Presian I, the Bulgars were contrasted with Christians, who were rightly considered synonymous with 'subjects of the empire.457 This opposition reveals a logic of identification, according to which religious affiliation defines social and political affiliation. A Mongol whom William of Rubruck met on his journey to Karakorum seems to have shared a similar way of thinking. He was a subject of Sartach, son of Batu Khan. He was said to object categorically to calling his master a Christian, since according to him, Sartach was a Mongol. ${ }^{458}$

In the case of such a strong link between ethnic identity and religion, conversion, especially when it was carried out by representatives of the elite, was frowned upon. From the account of Ahmad ibn Fadlan, we learn that one of the Uze leaders had to remain faithful to the religion of his ancestors, although he wanted to convert to Islam. This was because his subjects threatened that after his conversion he would not be allowed to remain their leader. ${ }^{459}$

Much more dramatic events are said to have affected the Pechenegs. Al-Bakrī reports that in the Hijri year 400 they were to receive a Muslim prisoner-ofwar familiar with sharia law who would spread the faith of Mohammed. After some time, when the number of believers had reached 12,00o, a conflict broke out between them and the Pechenegs who remained faithful to the religion of their fathers; the latter, despite a twofold advantage, suffered a defeat and were killed. ${ }^{460}$

456 Cf. Chapter 7 of the present book.

457 PI, no. 14, p. 165; Petkov 2008, 13. A fragment of the inscription reads as follows: 'When someone speaks true, god sees. And when someone lies, god sees as well. The Bulgars did many favours for the Christians, and the Christians forgot them. But god sees.' The inscription comes from southern Thrace and dates back to the year 837 .

$45^{8}$ Rubruc, XVI 5 (p. 205). 'Nolite dicere quod dominus noster sit christianus. Non est christianus, sed Moal'.

459 ibn Fadlan: ibn Fadlan, 206/207; Zeki Validi Togan 1939, 25-26; Kovalevskii 1956, 127; Frye 2005, 37.

46o Bakrī: Kunik, Rozen 1878, 59-6o; Göckenjan, Zimonyi 20o1, 222-223. Cf. Zakhoder 1967, $75^{-76 .}$ 
In the early 11th century, the Pecheneg nomads would thus became orthodox Muslims, with a scholar, expert on sharia law, and teacher of the Quran permanently residing among them. This information seems quite mysterious and should be treated with great caution, for no other source confirms its truthfulness. Some scholars, however, do consider it to be credible. According to them, the rapid spread of Islamization among nomads is supposed to prove this. ${ }^{461}$ Indeed, as the aforementioned remark by ibn Fadlan shows, the followers of the new religion, especially those who tried to impose their faith on the rest of their tribe, had to expect to encounter strong resistance. However, it is difficult not to notice in al-Bakrīs account a narrative schema, which reflects elements of the ideology of the jihad (e.g., the twofold advantage of the disbelievers over the Muslims, who nevertheless win). ${ }^{462}$ The date of the conversion of the Pechenegs raises doubts as well. ${ }^{463}$ It is difficult to explain why they would have adopted Islam in the 11th century, when their territories were so far from the most important Muslim political and cultural centres. ${ }^{464}$ Finally, it should be noted that mass conversion is not confirmed by archaeological sources either. According to this data, between the 9th and 11th centuries the vast majority of steppe-dwellers continued with their native burial practices. ${ }^{465}$ One should therefore maintain a certain degree of scepticism about the possibility of the conversion of the whole ethnos, while recognizing as probable the existence of a small group of Islamic neophytes who appeared among the Pechenegs as

461 Tryjarski 1972, 146; 1975a, 589-59o.

462 DeWeese 1994, 79; Göckenjan, Zimonyi 2001, 223 (n. 14).

463 Josef Marquardt had already expressed doubts in this matter and proposed to correct the date for conversion of the Pechenegs to Hijri year 300 (912/13 CE). Marquardt 1903, 72-74. The German scholar refers to al-Masudi's account, according to which among the Pechenegs who invaded the Byzantine fortress of Walandar (probably Debeltos) around 934, there were said to be many followers of Islam. al-Mas'ūdī, Les Prairies, II, 58-64; Pellat 1962, 177-179. Cf. also Göckenjan, Zimonyi 2001, 222 (n. 12).

464 Cf. Göckenjan, Zimonyi 2001, 222-223 (n. 13). The authors try to explain the late conversion of the Pechenegs as being rooted in politics. The steppe dwellers are said to have become the object of a Muslim missionary campaign, the aim of which was to gain an ally in the escalating struggle of the Arab world with Byzantium under Basil II and Rus' under Vladimir, a newly converted Christian. The tension between the Rus' and the Pechenegs, which reached its peak at the turn of the 1oth and 1th centuries, resulted in an increase in the influence of Islam among the Pechenegs. The mission of Bruno of Querfurt is also said to have served primarily political purposes, i.e., appeasing the Pechenegs and incorporating them into the alliance of Christian rulers (cf. below). This hypothesis, however, has very little foundation in historical sources.

465 During the excavations in a mixed Pecheneg and Uz cemetery, located not far from the former Khazar stronghold of Sarkel, only one (female) grave showed elements of a Muslim funeral rite (including the orientation of the deceased's head towards Mecca, the arrangement of the body on the side, and the lack of inventory). Pletneva 1990, 11-13. 
early as the 9th century and continued to remain with them. ${ }^{466}$ Most of the conversions probably took place in the Transvolga region, where the existence of strong Islamic influences is confirmed by the account of ibn Fadlan. It also shows what this 'faith' actually looked like among some steppe people who less insightful observers might have considered to be orthodox Muslims. During his journey through the land of the Uzes, the Abbasid diplomat noted:

I have heard them [i.e., Uzes - A.P.] declare: 'There is no god but God! Muhammad is God's emissary.' But it was a way of ingratiating themselves with the Muslims passing through their lands and not out of conviction. ${ }^{467}$

Elsewhere ibn Fadlan mentions an incident he considered offensive, i.e., when he was asked by one of the nomads whether Allah had a wife. ${ }^{468}$

Upon entering the Black Sea steppe, the Pechenegs found themselves surrounded by Christian states or states that were soon to be Christianized. This provided the nomads with an opportunity for intensive contact with the followers of yet another monotheistic religion. They most likely first came into contact with Christianity through their relations with the Byzantines. This could have occurred in individual contacts during the trading of goods, and in official contacts during the conclusion of political agreements, when each party affirmed their pledge to respect the agreement by invoking its own customary sources. ${ }^{469}$ Until the mid-11th century, however, we know nothing about any organized attempts by Constantinople to Christianize nomads, nor about any individual endeavors of this type. The first Christian mission among the Pechenegs confirmed by written sources is the expedition of Bruno of Querfurt, dating back to $1008 .{ }^{470}$ The missionary briefly described his stay

466 Some researchers assume that followers of Islam were present among the Pechenegs as late as the mid-12th century. This is based on the account of an Arab traveller, Abu Hamid al-Garnati, who, during his stay in Hungary, said he came into contact with two groups of Muslims. One of them, described by him as the Maghreb, is sometimes identified as the Pechenegs. Bol'shakov, Mogait 1971, 38-39, 75 (n. 112); Uzelac 2010, 70. However, this identification is questionable. Cf. Lewicki 1937, 111-114; Berend 2001, 66.

467 ibn Fadlan: ibn Fadlan, 202/203; Zeki Validi Togan 1939, 20; Kovalevskii 1956, 125; Frye 2005, 33-34.

468 ibn Fadlan: ibn Fadlan, 202/203; Zeki Validi Togan 1939, 21-22; Kovalevskii 1956, 126; Frye 2005, 34 .

469 DAI, VIII 15-18 (pp. 54-57).

470 The most recent studies on St. Bruno of Querfurt's expedition to the Pechenegs: Tyszkiewicz 2009, 71-89, 95, 101-103; Dudek 2010, 241-254; Paroń 2013a, 161-178; Kollinger 2013, 187-202. Cf. also considerations in Chapter 6 of the present book. 
with 'the most cruel of all pagans' in his Letter to King Henry II. ${ }^{471}$ He writes about the conversion of 30 souls, which should be interpreted as a symbolic number communicating his having planted a sufficient number of seeds to ensure the independent existence of a Christian community, ${ }^{472}$ whose further existence and development would require the consecration of a bishop, which soon followed. The new bishop was most likely an individual connected with Kievan Rus'. ${ }^{43}$ Bruno also noted that he was able to bring about peace between the Pechenegs and Vladimir the Great. The latter sent one of his sons to the nomads as a hostage in order to secure the new agreement. Later, close contacts between Sviatopolk I and the Pechenegs suggest that he was the one sent. We do not know anything further about the lives of this bishop and his Pecheneg neophytes. It is thus difficult to say whether this new Christian community survived. Bruno claimed that he visited three out of four 'parts' of the Pecheneg lands, while 'emissaries of the better [ones]'474 came to see him from the last one, which would indicate that the seeds of the Gospel had been widely sown. New conflicts between the Rus' and the Pechenegs and the gradual retreat of the nomads from the Black Sea steppe, however, must have weakened the contacts between the new bishop and Kiev, and destroyed the fruits of Bruno's missionary work.

A mass conversion of the Pechenegs was recorded in the mid-11th century by Byzantine sources. The first to be baptized (together with his followers) was Kegenes, an ambitious leader who was in conflict with bulk of the ethnos. The ceremony took place on the banks of the Danube and was performed by Euthymios, a pious monk. Soon afterwards, the main group of the Pechenegs moved onto the territory of the empire. In their case, only members of the elite, including Tyrach, the leader of the whole ethnos, were considered 'worthy of baptism'. 475 There is no surviving information on the conversion of the remaining Pechenegs. The smooth and peaceful course of the ceremony and the large number of neophytes baptized have been seen by contemporaries as a great success for the Church and the Byzantine Empire. ${ }^{476} \mathrm{~A}$ comparison with the seemingly modest results of St. Bruno's mission seems to strengthen

\footnotetext{
471 Bruno, 99-101.

472 Paroń 2013a, 177. Cf. Rosik 2010, 209-210 (interesting comparative data).

473 Cf. Poppe 1968, 188-189; 1999, 228; 2008, 56.

474 Bruno, 100 (v. 6-7). ‘[...] tres partes circuiuimus, quartam non tetigimus, de qua meliorum nuntii ad nos venerunt [...]'. Cf. Chapter 6.

475 Io.Scyl., 457 (v. 10-14), 459 (v. 80-85); Wortley 2010, 428, 430; Io.Zon., XVII 26 (p. 643); Trapp 1986, 107. Cf. Ivanov 2003, 226-227; 2008, 328.

476 Io.Maur., 143-144 ( $7-8), 145$ (§ 12-13). Cf. Malamut 1995, 121; Ivanov 2007, 255-256. See also Chapter 7 of the present book.
} 
this impression. However, the history of the later relationship between St. Bruno and the Byzantine Empire shows that Constantine Monomachos did not achieve very much. This baptism did not bring about any significant spiritual or mental change in the Pechenegs. ${ }^{477}$ The enthusiasm of some witnesses to this event should therefore be contrasted with the bitter realism of the statements of later authors, in particular, Michael Attaleiates and Michael Psellos. Their disappointment resulted mainly from the fact that the baptism did not change the attitude of nomads towards the empire in any significant way. Although they formally became a part of the empire, there was no increase in the degree of their loyalty to the empire. ${ }^{478}$ The lack of data indicating any pastoral activity among the new subjects of the empire, however, is puzzling. Meanwhile, it would seem that the metropolis of Dristra, with its five suffragan dioceses, would have had sufficient potential to successfully Christianize the Pechenegs.

The passivity of the Byzantine Church could have been exploited by dualist sects operating in the Balkans. Vasili Vasilievskii notes seeing the early influences of Manicheanism among the Pechenegs. The peoples living north of the Aral Sea, including the Pechenegs, were said to have fallen under the influence of followers of Mani's teachings, who were numerous and active in Transoxiana. ${ }^{479}$ It is much more likely that the Pechenegs were influenced by the Paulicians. This seems to be proven by their close political contacts with representatives of this religious community. As Dimitri Obolensky has rightly assumed, the arrival of the Pechenegs in the Balkans may have aroused the interest of the heretical Paulicians, who saw them as potential converts. ${ }^{480}$ Although we know nothing about the Paulicians' missions among the nomads, political cooperation between them, facilitated by the anti-Byzantine attitudes shared by both communities, has been confirmed. Mentions of Paulician leaders marrying the daughters of prominent Pechenegs date back to the 1070s and 1080s, and these marriages strengthened the alliance that had been formed between the two groups. ${ }^{481}$ It is very possible that the nomadic mentality was

477 Cf. Tryjarski 1975a, 592-593.

478 Mich.Att., 54/55. Cf. Ivanov 2003, 230.

479 Vasil'evskii 1908, 40-41.

48 o Obolensky 1948, 192-193.

481 Lekas, who was Greek and a follower of Paulicianism, was married to a Pecheneg woman. In 1078 he agitated people living near Serdica and Niš to rebel against the Byzantine Empire. Mich.Att., 550/1; Scyl.Cont., 184. In 1084, a rebellion was sparked by Traulos, another Paulician, was also associated with the Pechenegs. An.Kom., vi 4.2-4 (p. 174); VI 14.2 (pp. 199-200); Sewter 2009, 158-159, 182-183. Cf. Obolensky 1948, 189-192 and Chapter 7 of the present book. 
well suited to the Paulicians' activism, which made them a militant community. The teachings of Bogomilism, which involved asceticism and withdrawal from life, probably seemed much less attractive, although the Pechenegs could have also been exposed to this sect in the Balkans. ${ }^{482}$ This applies especially to those groups of nomads who, after the battle of Lebounion, settled in the Moglena region, east of Vardar, where followers of this latter heretical sect were relatively numerous. ${ }^{483}$

Byzantine authors, however, considered the Pechenegs adamant pagans or completely godless people, which is clearly indicated by the passage by Michael Psellos quoted earlier. In regard to nomadic peoples, the latter view was very widespread and probably stemmed from a misunderstanding of the nature of their beliefs or a deliberate disregard for them. ${ }^{484}$ However, despite clear revulsion towards the Pechenegs expressed by Byzantine writers in the 11th and 12th centuries, we must admit that their harsh diagnosis reflected to a good extent the actual state of affairs. The majority of nomads probably held to their native Turkic beliefs. ${ }^{485}$ Other religions they encountered in the course of their history may have influenced them, but they probably did not cause the Pechenegs to abandoned their original beliefs in any important respects. Traditional beliefs continued to shape the Pecheneg system of values to a significant degree.

The fact that we know so little about these beliefs is truly unfortunate. The scarcity of narrative sources is not compensated for by archaeological material. For this reason, we are able to recreate only a general outline of the Pechenegs' funeral rites and put forward a few elementary hypotheses concerning their

482 On Bogomilism in general: Obolensky 1948; 1994b, 259-280; Angelov 1961. On the Manichean heresy: Runciman 1947; Schmaus 1951, 271-299.

483 Io.Zon., XVIII 23 (p. 741); Trapp 1986, 167. Cf. Obolensky 1948, 193.

484 Cf. Ammianus Marcellinus on the Huns: '[...] nullius religionis vel superstitionis reverentia aliquando districti [...]'. Amm.Marc., XxxI 2.11 (p. 386). A less radical stance towards the Mongols, although in many respects a related one, is taken by Giovanni da Pian del Carpine. Although they are not completely godless, because they believe in one God, who is the creator of all that is visible and invisible, as well as the giver of punishment and rewards (bonarum), they do not worship him in any way (di Carpine, III 2 (p. 236)). They know nothing about eternal condemnation or eternal life, and imagine the afterlife as a visible world. (di Carpine, III 9 (p. 240)).

485 According to al-Bakrī, before they converted to Islam, the Pechenegs practiced the religion of 'magi' (mağūs). Bakrī: Kunik, Rozen 1878, 59; Göckenjan, Zimonyi 2001, 222. Cf. Zakhoder 1967,75 . Some researchers consider this information to be a cause for considering the influence of old Iranian religions, mainly Mazdaism and Zoroastrianism, among the Pechenegs. Tryarski 1972, 140, 142-146; 1975a, 583, 585-589. The word used by al-Bakrī may mean simply an ethnic, pagan religion, or most probably the native beliefs of steppe dwellers. See Shcherbak 1959, 372; Lewicki 1954, 164; Göckenjan, Zimonyi 2001, 222 (n. 11). 
ideas about the afterlife. There are also very few traces of their symbolic culture - a phenomenon that is extremely important for understanding the religiosity of any community. Due to this lack of sources, the Pechenegs' native beliefs have thus far been merely inferred, mainly on the basis of comparative analyses. It has been assumed, for example, that as a Eurasian nomadic people, they must have shared a number of religious traditions typical of the Great Steppe. On that basis, the Pechenegs are attributed the practice of shamanism. ${ }^{486}$ However, this religious phenomenon tends to be understood in different ways. Some researchers treat it as a set of specific religious phenomena and common practices, such as rites of passage, the cult of ancestors, mysticism and sacrifice. Shamanism perceived in this way may, in various forms, play a role in various religious systems, including monotheistic ones. This view is contrasted with another, according to which shamanism is a separate religious system that originated in Siberia, from where it spread to the steppe. ${ }^{487}$ Both positions only seem to be distant from one another. The belief that ecstatic experience - perceived to be a fundamental element of the shamanic complex - was universal is compatible with the conviction that such experiences have had a fundamental and constitutive importance for the beliefs of some communities, including the peoples of the steppe. ${ }^{488}$

Shamanism is based on a characteristic cosmology, which assumes the division of the cosmos into two or three vertically arranged zones (heaven and earth, or heaven, earth and the underworld), which can communicate with one another. ${ }^{489}$ This kind of 'journey' to heaven or underground is accomplished by going into a trance. Shamanism accepts the existence of special relationships between animals and zoomorphic spirits. It also applies a specific 'eschatology', according to which one's departure from this world, as well as falling ill, is always due to supernatural factors, i.e., the influence of evil spirits. The dead do not end up in heaven or hell, since the original beliefs of the Altai peoples did not involve the notion of punishment for the crimes committed and rewards for the good deeds performed during the course of one's lifetime. Only under the influence of monotheistic religions, mainly Christianity, did the beliefs of some inhabitants of Inner Asia incorporate a conviction that good people were headed 'up above', while bad people - 'down below'490

\footnotetext{
486 Macartney 1929, 354; Tryjarski 1972, 140-141; 1975a, 584-585; Spinei 2003, 107; 2009, 274.

487 Szyjewski 2001, 288.

488 Roux 1984, 61-98; 1988, 519; Eliade 1971, 504, 507; Szyjewski 20o1, 288-289; 2005, 5-6.

489 Roux 1984, 62; Szyjewski 2005, 153-184.

49 o Kałużyński 1968, 131; 1983, 96; Roux 1984, 254, 258; 1963, 106 (the researcher stresses that all the terms used by the Turks to describe hell were of foreign origin); Tryjarski 1991, 62-64, $72-74$.
} 
The central figure in this religious system is the shaman, who, according to Mircea Eliade, 'plays an essential role in the defense of the psychic integrity of the community'491 He has the ability to heal by bringing the soul of a sick person abducted by demons back. The shaman also fights black magic, and works as a mediator between the realm of the living and the realm of the dead, gods and demons. ${ }^{492}$

As the nomads imagined it, life after death was an almost exact copy of life on Earth. After passing to the other side, they would have to, as they did earlier, graze their herds, fight, rob, and love. ${ }^{493} \mathrm{~A}$ common cultural phenomenon among steppe peoples was therefore equipping the deceased with what they would need in the underworld. This custom was reflected in the contents of funeral inventories discovered by archaeologists. A funeral ceremony included the sacrifice of a horse, the remains of which were often found in burials attributed to the Pechenegs. ${ }^{494}$ Comparative data seems to suggest that the animal was supposed to be a guide and a means of transport by means of which the soul of the deceased would be transported to the afterlife. ${ }^{495}$ In the funeral inventories of the Pechenegs there have also been found elements of horse tack (most often stirrups and bits), weapons (arrowheads, bow covers, spearheads, and sabres - the latter relatively rarely), parts of belts (including buckles and ornaments, most often made of bronze), knives, flints, and mutton bones, which may constitute a trace of the funeral banquet, and occasionally clay pottery, usually made without the use of a potter's wheel. ${ }^{496}$ These modest relics were probably the deceased's equipment for the afterlife.

The concept of the lack of punishment in the afterlife for crimes committed on earth, commonly attributed to steppe peoples, is an interesting issue. Such a state of affairs would indicate that the ethical aspect of the native beliefs of the Altai peoples was noticeably limited or completely non-existent. They

491 Eliade 1988, 19.

492 Eliade 1988, 20.

493 Roux 1963, 107; 1988, 518, 527-528; Tryjarski 1991, 70-71; 195-197, 199, 201.

494 The remains of horses were usually placed next to the human body on a step elevated for that purpose or at the bottom of the grave. The skeleton of the animal, usually incomplete (usually the head with anterior and posterior limbs, cut off at the second or third joint, and then arranged in anatomical order), was sometimes saddled and bridled. Pletneva 1958, 153-155; 1981, 218; Dobroliubskii 1986, 49-5o; Garustovich, Ivanov 20o1, 94-95; Atavin 2008, 84-86 (in the material collected by Atavin, horse remains were found in more than half of the burials attributed to the Pechenegs).

495 ibn Fadlan 208/209; Zeki Validi Togan 1939, 27-28; Kovalevskii 1956, 128; Frye 2005, 39. ibn Fadlan described the sacrifice of the dead man's horse on which, according to the Uzes, he was to reach 'paradise'.

496 Garustovich, Ivanov 2001, 94-95, Atavin 2008, 82-84, 85. 
probably lacked the notion of sin and of an inevitable divine punishment that threatens believers for committing sinful acts. Both of these notions, in contrast, were central to the monotheistic religions (Christianity, Islam) professed by the authors who described the Pechenegs. Observing their political behaviour, which these writers saw as often being expressed in unfounded breaches of faith, pillaging and cruelty, they may have assumed that steppe dwellers were committing them because they were not restrained by a deity, who, like the Christian God, would punish them for their crimes. The matter, however, appears to be more complex. The notion of sin and an ethical system built upon it probably replaced a variety of taboos that previously functioned in Pecheneg communities, and which prescribed certain behaviours as elements of their relations with numerous spirits and deities. Within the framework of such a religious outlook, all misfortunes, whether affecting an individual or the whole community, were interpreted not as a punishment for offences committed against one's neighbour, but as a punishment for offending one of the supernatural beings by violating a taboo concerning them. ${ }^{497}$ Such a means of reasoning among the steppe people was noticed by the keener observers who came into contact with them. John of Pian de Carpini attributes to the Mongols a number of religiously motivated prohibitions, the violation of which was punished very severely for fear of the consequences. ${ }^{498}$

Their attitude towards other people is a separate issue. Pecheneg communities, like those of other nomads, were not anomic. Customs and legal rules regulated relations within the community; however, outside of it, as we noted above, these rules were more loosely applied. Violence in relations with outsiders was not strictly forbidden. Likewise, plunder, severely punished when it was committed against members of the native community, was admissible or even accepted when the victim was a stranger. ${ }^{499}$ Of course, for practical reasons, the most extreme behaviours were limited. Attacking and robbing every newcomer who appeared in areas controlled by the Pechenegs would have led to a disruption of trade, which, as we have seen, was of considerable importance to the steppe peoples. The case of Bruno of Querfurt, whose first contact with the Pechenegs seemed to confirm all the flaws attributed to nomads, also

497 Kałużyński 1968, 141; 1986, 108-118.

498 According to Carpine it was a $\sin$ (peccatum) among the Mongols to put a dagger into fire or to touch fire with a dagger, lean on a whip while driving a horse, touch arrows with a whip, catch or kill young birds, spill milk on the ground, urinate in a yurt, spit out a bite of food received during a feast, or step on the entrance to the yurt. The last three offences were punishable by death. di Carpine, III 7 (pp. 239-240).

499 Kamocki 2003, 62. For the Bedouins and the Kyrgyz, property acquired through robbery was a source of pride. 
seems significant. However, when they became aware of his intentions, they allowed him to stay and did not interfere in Bruno's missionary activities, or at least we do not know anything about this. ${ }^{500}$ Personal relationships established through trade or diplomatic contacts were also a mitigating factor in the behaviour of the steppe dwellers towards people from outside their community. A stranger could become the 'comrade' (drug') of a particular Pecheneg, as shown by the account in The Primary Russian Chronicle of the friendship between an unnamed Pecheneg and Pretich, the governor of Prince Sviatoslav Igorevich. ${ }^{501}$ Close relations of some kind also connected the nomad Tatranes and Emperor Alexios I Komnenos. The Pecheneg switched sides numerous times; he would support the Byzantines, then return to his kindred people. Nevertheless, he seems to have always remained personally loyal to the Emperor. ${ }^{502}$ The relations between the Khersonites and the Pechenegs who traded with them, as described in the second part of this chapter, were also conducive to making personal contacts based on friendship.

Such ties were valuable not only for political or economic reasons; sometimes they simply saved lives, as the story of the Byzantine commander Katakalon Kekaumenos, who later became the duke of Antioch, clearly shows. ${ }^{503}$ He was seriously injured in the battle of Diakene (1049), which was lost by the Byzantine forces. ${ }^{504}$ As he lay on the battlefield, unconscious from the loss of blood, he was recognized by Koulinos (Goulinos), most probably the son of the famous Kegenes. The Pechenegs seated Katakalon on his horse, took him to a tent and cared for his wound, thanks to which the Byzantine commander survived. ${ }^{505}$ It seems that Koulinos was not motivated solely by a desire to receive a ransom. The Katakalon's injuries were so serious that hopes for his survival, and thus any gratification, were in fact low. If Koulinos was only interested in profit, he would have probably simply killed and robbed the wounded commander. ${ }^{506}$

\footnotetext{
500 Bruno, 100-101.

$501 \quad$ PVL 1, AM 6476 (968), col. 66-67.

502 An.Kom., VII 10.1 (pp. 229-230); Sewter 2009, 210.

503 He was not the author of Strategikon. Shepard 1992, 171-181.

504 According to John Skylitzes: 'one [of his wounds] laid bare his skull [...] from the peak to the eyebrow, another on the collar had cut the neck at the root of the tongue, right through to the mouth [...]'

505 Io.Scyl., 469 (v. 50-6o); Wortley 2010, 439.

506 Jonathan Shepard suggests a lasting friendly relationship existed between Koulinos and Katakalon. This would be evidenced by the seal of an imperial commander, dated 1054/55, discovered on the lower Danube. Katakalon Kekaumenos had already become a duke of Antioch by that time. Shepard 2013, 222-224.
} 
However, the Pechenegs were ruthless towards their enemies and did not refrain from exercising extreme, even bestial cruelty. The rules of war on the steppe, which assumed the complete destruction of the enemy, did not allow for mercy to be shown to the defeated. The nomads did not hesitate from killing captive warriors, and their murdering of prisoners aroused considerable disgust among Byzantine authors. Michael Psellos writes about this practice among the Pechenegs with a similar revulsion. ${ }^{507} \mathrm{~A}$ very characteristic example, described by John Skylitzes, was the behaviour of Kegenes, who crossed the Danube together with two of the thirteen Pecheneg tribes and entered into the service of Constantine IX Monomachos. ${ }^{508}$ Shortly afterwards, when the remainder of the ethnos moved onto Byzantine lands, Kegenes together with the imperial troops inflicted a devastating defeat on them. These Pechenegs and their leader Tyrach were taken captive and were at the mercy of their conquerors. Kegenes strongly advised the Byzantine commanders, almost pleading with them, to slaughter the captured Pechenegs, starting with the young men. He referred to a certain barbarian adage ( $\pi \alpha p o i \mu i \alpha \beta \alpha \dot{\alpha} \beta \alpha \rho \rho \varsigma)$, which succinctly expressed that a snake should be killed in winter, when it cannot move its tail, before it causes suffering and trouble when heated by the sun. ${ }^{509}$ The captives - it should be emphasized that this included both warriors and their families - could have numbered from several dozen thousand up to a hundred thousand. Kegenes' proposal was probably in fact to murder the elites of the individual tribes, and to spare the rest of the people, as the ambitious leader probably wanted to assume leadership over the entire ethnos. ${ }^{510}$ Such a course of action would seem to correspond to the logic of steppe battles, during which only members of the aristocracy were ruthlessly eliminated, since, if left alive, they could have attempted to retaliate. However, the Byzantine commanders considered the solutions proposed by Kegenes to be 'a barbaric and impious act, unworthy of Roman civilization.'511

\footnotetext{
507 Cf. note 6o.

508 Cf. the conclusion of Chapter 6 of the present book.

509 Io.Scyl., 459 (v. 67-70); Wortley 2010, 430.

510 Genghis Khan ordered the murder of all Tatars taller than the axel of a carriage, which in practice meant the fulfillment of Kegenes' idea, i.e., the killing of the whole population with the exception of children (starting with young men). In The Secret History of the Mongols, however, there is a statement that those of the Tartars who survived were to become slaves. The conclusion is that only the elites were exterminated. Genghis Khan dealt with the Taiči'ut in a similar way, i.e., he murdered the aristocrats and subjugated the people who used to be their subjects. Rachewiltz 2004, I, 70, 77 .

Io.Scyl., 459 (v. 71-72). Cf. Bonarek 2003, 95-96.
} 
John Skylitzes also mentions the ruthless murder of the inhabitants of Thrace and Macedonia by the Pechenegs after their victory in the Battle of Adrianople (June 1050). At that time, the entire people fell victim to their atrocities, and not even infants were spared $(\tau \dot{\alpha} \theta \eta \lambda \dot{\alpha} \zeta o v \tau \alpha \nu \eta \dot{\eta} \pi 1 \alpha) \cdot{ }^{512}$ Michael Attaleiates writes about another manifestation of incredible barbarity, the victim of which was the patrician Michael Dokeianos, one of the Byzantine commanders taken captive at Adrianople. When he was brought before an unidentified leader of the Pechenegs, he managed to grab his sword and kill him. In retaliation, he was summarily executed. His abdomen was then cut open, his intestines pulled out, and his severed hands and legs placed inside. ${ }^{513}$ Yet, Dokeianos' behaviour had indeed been reckless. Although he proved his incredible courage and contempt for the enemy, which, of course, was appreciated by Michael Attaleiates, we can assume that such a deed by a prisonerof-war would have met with harsh retaliation by any army. Finally, Anna Komnena mentions that the Pechenegs, after they won the battle with Alexios Komnenos, had intended to murder their Byzantine captives. Ultimately, however, this desire was outweighed by the pragmatic stance of the common warriors, who opposed such a mass extermination and hoped to obtain a large ransom instead. .14

In order to avoid excessive one-sidedness, it is worth noting that the Byzantines also succumbed to a kind of 'moral fatigue'. The uplifting spirit of Skylitzes' story about the imperial commanders' behaviour towards Tyrach's Pechenegs should be contrasted with the history of the captives from Lebounion (1091). On the night after the battle, a significant part of the steppe people were murdered allegedly without Alexios I's knowledge. ${ }^{15}$ This circumstance raises the question of whether the demise of the Pechenegs as an independent ethnos, which occurred at that time, was a consequence of losses suffered during the battle itself, or rather a 'final solution' on the night after it?

A long-lasting conflict with any enemy inevitably leads to the dehumanization of the opponent, which in turn leads to the weakening of all moral barriers. In the 108os, the Pechenegs became a very serious threat to the empire. Their attitude must have aroused particular frustration among the Byzantine elites, who witnessed the total failure of their earlier hopes to assimilate the steppe dwellers. Given this situation, a conviction must have arisen that the

512 Io.Scyl., 471-472 (v. 23-26); Wortley 2010, 440.

513 Mich.Att., 6o/61. Skylitzes knows about Dokeianos' death, but does not include the gruesome details. His accounts seem to indicate that the patrician fell in battle. Io.Scyl., 470 (v. 88-89); Wortley 2010, 439 .

514 An.Kom., VII 4.4 (p. 216); Sewter 2009, 197.

515 An.Kom., VIII 6.1-2 (pp. 249-250); Sewter 2009, 227-228. 
only possible solution was the total extermination of the Pechenegs. Anna Komnena's shameful way of handling the Lebounion night massacre proves, however, that it was seen, at least by some parts of the Byzantine public, as a violation of moral standards.

The steppe people understood this in the exact opposite way. Killing a defeated enemy was not a sign of helplessness when no other means were available, but a standard, preventive measure which ruled out the possibility of retaliation. The slaughters attributed to the Pechenegs seem trivial compared to the feats of Genghis Khan or Amir Timur (Tamerlane). During their campaigns against the political powers of Central Asia and the Middle East, entire cities were razed to the ground and their inhabitants, if they did not have skills sought after by the aggressor, were often exterminated. ${ }^{516}$ The atrocities they committed, which can only be attributed in part to the demands of politics or military strategy, lead researchers to look for explanations in the realm of their beliefs.

It is a fact that in nomadic communities, military prowess, measured by the number of enemies killed, was probably the most cultivated virtue. This is hardly surprising given the fact that these were communities in which every man capable of carrying a weapon was a warrior. Herodotus recalls that only those Scythian warriors who brought the heads of the enemies they had killed to their leader received a share of the plundered booty. They could also take part in community ceremonies, during which they received a cup of wine. ${ }^{517}$ According to Sima Qian, an almost identical custom was known to the Xiongnu people. ${ }^{518}$ The Chinese historian adds that the one who brought the body of a Xiongnu warrior killed in battle received his possessions. ${ }^{519}$ Virtus militaris was therefore the main, if not sole, source of wealth. Possessing it also guaranteed one's membership in the community, while its absence meant exclusion from it.

516 On the performance of the army of Genghis Khan in Khwarazm, Khorasan, Armenia, Georgia, and Shirvan: Rašid ad-Din I 2, 209-213, 218-219, 227-228, 240-245. On the conquest of Iran by Hulagu Khan and the resulting destruction and massacres: Rašid ad-Din III, 25-43. Cf. Malowist 1976, 540-544. On Timur's expeditions and atrocities in connection with them: Gafurow 1991, 504-507; Małowist 1991, 41-46; Grousset 2006, 541, 545. Timur's inclination to cruelty distinguished him from other steppe rulers. In 1387, after capturing Isfahan, he ordered the heads of 70,00o inhabitants of the city to be cut off and a pyramid erected out of them. The same happened after the suppression of an uprising in Baghdad. At that time, the number of victims was said to amount to 9o,ooo. 120 pyramids were constructed from these heads.

517 Hdt., IV 65-66 (pp. 262, 264).

518 Watson $1961,164-165$.

519 Watson 1961, 165 . 
The bravery of a particular warrior was also emphasized in funeral rites. In Chinese chronicles, we find the following information about the funeral rites of the Blue Turks (Tujue):

In the grave they make a space where they place a painted portrait of the deceased and battle scenes in which he participated. If the deceased had ever killed a man [in battle], they place a stone [in front of the grave], i.e., or each man killed they erect a stone. ${ }^{520}$

A similar way of accentuating the courage of fallen warriors was also found in the Black Sea and Caspian steppe. The Persian poet Nizami (12th/13th century) mentions stone figures, most probably stone babas, which are surrounded by a forest of wooden arrows, as numerous as 'the grass on the seashore.'521 According to Wacław Kotwicz's interpretation, these arrows symbolized killed enemies, like the stones used in the Turkic ceremony. ${ }^{522} \mathrm{~A}$ fragment of the Ahmad ibn Fadlan's account takes us a step further. He writes about the funeral rites of the Uzes:

If he has shown great bravery and killed someone, they carve wooden images, as many as the men he has killed, place them on top of his grave and say, "His retainers who serve him in the Garden." 523

Ibn Fadlan's observation is of particular value to our discussion, not only because of the cultural proximity of the Uzes to the Pechenegs (archaeologists tend to almost equate the two), but above all because of their shared belief that after death a slain enemy became the slave of the warrior who killed him. It seems that this belief was quite common among the steppe peoples. ${ }^{524}$ It is also found in Hungarian chronicles, which report on the adventures of two Old Hungarian warriors named Bulchu and Leel. During the invasion of Bavaria they are said to have been captured by the army of Conrad I (911-918). Before their death, one of the two, the chronicles usually point to Leel, craftily killed the German ruler. At the time of the murder, he is supposed to have said to his victim: 'You will go before me and you will serve me in the afterworld.' The chronicles comment on this legendary story by saying that the 'Scythians'

\footnotetext{
520 Liu Mau-Tsai 1958, 42. English translation: Šmahelová 2014, 104-105.

521 Kotwicz 1928, 5 .

522 Kotwicz 1928, 6.

523 ibn Fadlan: ibn Fadlan, 208/209, Zeki Validi Togan 1939, 27; Kovalevskii 1956, 128; Frye 2005, 39 .

524 Małowist 1991, 46.
} 
believe that the dead are slaves of their murderers in the afterlife. ${ }^{525}$ The fear of such a fate prompted warriors to commit suicide, as a last resort in a hopeless situation. This is evidenced by Leo the Deacon's account on the beliefs of members of the warriors (druzhina) of prince Sviatoslav Igorevich. ${ }^{526}$ If the Byzantine author had in mind here mainly the Rus', this would be proof that the set of beliefs in question was not typical only of the peoples of the steppe. ${ }^{527}$

These beliefs belonged, however, to the warrior ethos, which differed fundamentally from the ideal of the soldier or knight developed by the Roman and Judeo-Christian traditions. In the portrayals of the steppe dwellers written by Byzantine authors, but not only by them, the image of nomads as hordes of predatory animals that owe their strength in combat mainly to their wildness was very common. They did not prevail thanks to their tactics, strategy and weaponry - in a word, the art of war - but rather to their primeval, 'animal fierceness. ${ }^{528}$ This image is undoubtedly a stereotype, but to a certain extent, it appears to be based on real-life events. The military skills of steppe societies were highly developed in many respects, but the fact remains that in combat, like other barbarian peoples, they sought to become something akin to wild carnivorous beasts. Certain rituals, such as drinking the blood of a defeated enemy or human blood in general, ${ }^{529}$ and perhaps cannibalistic practices, ${ }^{530}$ were meant to achieve this goal. By means of such actions, a warrior renounced his humanity, and therefore the limitations, laws and customs that regulated

525 Leel was said to ask to be allowed to blow the horn before his death. When they agreed and the instrument was handed over to the prisoner, he unexpectedly hit Conrad's forehead with it, which killed the German king. Sim.Kéza, 169; Chr.Hung., 3o8; Chr.Mon., 65; Chr.Müg., 142-143; Chr.Ryth.Müg., 253-254; Joh.Thur., § 243-244 (p. 71).

$5^{26}$ LeoDiac., IX 8 (pp. 151-152); Talbot, Sullivan 2005, 195.

527 Most researchers assume, however, that these beliefs were typical of the steppe dwellers, which Leon mistakenly attributed to the Rus'. Moravcsik 1955, 74-76; Terras 1965, 401.

528 Paroń 2011, 127-128.

529 According to Herodotus, a Scythian drinks the blood of the first opponent he felled in battle (Hdt., IV 64 (pp. 26o, 262)). Drinking human blood was commonly attributed to Hungarians in the early period of their history. Regino, sub anno 889 (p. 133), and many Latin chroniclers after him. Cf. Paroń 2011, 131-132. See also Liutprand., II 2 (p. 37).

530 The Hungarians reportedly devoured the hearts of the people they captured (Regino, sub anno 889 (p. 133)); the Pechenegs were also said to practice cannibalism and eat the flesh of corpses (cf. part two of this chapter). Generally speaking, ascribing cannibalistic practices to various Eurasian nomadic peoples was a fairly common motif in medieval European literature. It is usually difficult to determine whether we are dealing with slander, a real ritual that has been greatly exaggerated, or an extreme hunger-driven necessity. Cf. Guzman 1991, 31-68; Schmieder 2005, 159-179; Gießauf 20o6, 118, 123, 129; Paroń 2011, 131-132. 
human behaviour ceased to apply to him, as he had become a wild beast possessed by furor heroicus. ${ }^{531}$ The opponent was also dehumanized and was granted the status of game. If he were a particularly dangerous and powerful enemy, when he died, he would provide a trophy in the form of specially processed skull. ${ }^{532}$ This custom, common among the steppe peoples, was also practiced among the Pechenegs. ${ }^{533}$

During a military expedition, steppe warriors would become a horde of wild animals, a pack of wolves that would tear to pieces everything and everyone they encountered. Their actions were controlled only by their specific tactical and strategic goals. Glaring displays of cruelty could be interpreted as an element of their terror tactics, aimed at weakening the will to fight in the community under attack. A shock dose of terror atomizes a society, turning it into a group of intimidated individuals incapable of resistance. Explanations of this kind, however, should not obscure the fact that an attack on another community could have been understood by the steppe dwellers as a kind of primeval hunt, during which warriors pursued prey like a horde of wild animals. From such a perspective, every military expedition was a re-creation, a renewal, of a primeval myth, with every warrior becoming a wolf, a hunter and a predator. ${ }^{534}$ Crossing beyond the boundaries of humanity, becoming a wild beast, and unleashing its distinctive murderous impulses was exactly the opposite of the military ethos typical of the Byzantine Empire and Latin Europe. The Roman and Judeo-Christian traditions assumed that a primeval warrior would be tamed and his thirst for murder curbed. He was to turn into a soldier or knight who turns to violence in strictly defined situations, and never against the defenceless or those who, like prisoners-of-war, relied on his grace.

The military prowess of the Pechenegs, though frightening, prompted neighbouring political powers to ally with them or simply benefit from their short-term military support. Emperor Constantine VII Porphyrogenitus was in favour of close cooperation with these nomads. Other rulers were more inclined to treat them as useful mercenaries. Even the most short-lived cooperation required a guarantee of loyalty from the steppe people. They were often required to hand over hostages, which is what the Byzantine patrician John Bogas did when he formed an alliance with the Pechenegs against Simeon, the

531 Eliade 1972, 5-8, 18-20.

532 Ma Yong 1989, 184-19o.

533 The Pecheneg prince Kuria supposedly made a cup out of the skull of Prince Sviatoslav Igorevich after he was killed at the Dnieper Rapids. PVL 1, AM 6480 (972), col. 74.

534 Cf. Eliade 1988, 1. 
ruler of Bulgaria. ${ }^{535}$ Constantine viI advised following the same procedure. ${ }^{536}$ The Rus' also demanded hostages, as evidenced by the example of Prince Igor, who benefited from the help of Pecheneg mercenaries during his expedition against the Greeks (944). ${ }^{537}$ Such agreements were confirmed with solemn vows, which, as Constantine Porphyrogenitus writes, the steppe people swore according to their own customs. ${ }^{538}$ Unfortunately, we do not know what the text of the oath sworn by the Pechenegs or the related ceremony was like, but its form can be inferred from comparative data. For example, it is known that the Danube Bulgars swore an oath on their swords. ${ }^{539}$ The ceremony may have been accompanied by a sacrifice, as indicated by the passage from Michael Psellos cited earlier in the chapter. ${ }^{540}$ While taking the oath to adhere to a peace agreement with Byzantine, the Bulgars representing Omurtag chopped up bodies of dogs they had sacrificed earlier. ${ }^{541}$ The Mongols preceded their taking of a 'supreme oath' with the sacrifice of a stallion, an ox and a male dog. The animals were killed with a sword, and the following pledge was uttered:

Oh God! Oh Heaven! Oh Earth! Listen to us. We are taking an oath [...]. If we do not keep our word and break our oath, we should become like these animals. ${ }^{542}$

However, even the most solemnly sworn agreements could be broken. Byzantine and other authors constantly complained about betrayals of trust by the Pechenegs. This was an element present in almost every description of them. It is difficult to resist the impression that attributing breeches of faith to steppe peoples was a kind of topos. Pechenegs, as pagans and barbarians, by definition deserved epithets like 'unfaithful and infamous'. In some cases, however, we are dealing with more than just a stereotypical quality. Nikephoros Bryennios, duke of Dyrrachion and a contender for the imperial throne after the overthrow of Michael vir Dukas, enjoyed a peculiar form of loyalty from the steppe dwellers. Though the Pechenegs were allies in his struggle for

535 Th.Cont., 386-387; Io.Scyl., 201-202 (v. 49-55); Wortley 2010, 196.

536 DAI, VII-VIII (pp. 54-57).

537 PVL 1, AM $645^{2}$ (944), col. 45.

538 DAI, VIII (p. 56/7).

539 Nic.Pap., LXVII (p. 591). Cf. Zlatarski 1972a, 181-189; Tryjarski 1975, 327.

540 Cf. note 6o.

541 Th.Cont., 31. Cf. Tryjarski 1975, 327. The sacrifice of dogs while swearing to abide by political treaties was also practiced by the Hungarians and the Cumans. Sinor 1992, 301-307.

542 Rašid ad-Din, I 2, 189; Togan 1998, 94. Cf. Kałużyński 1983, 99. Another oath-taking ritual recorded in The Secret History of the Mongols was the cutting in half crosswise of a stallion and a mare. Rachewiltz 2004, I, 63. 
power, this did not prevent them from surrounding Adrianople, home of the Bryennios family, and threatening to attack the city. They left only after obtaining a handsome ransom. ${ }^{543}$ They behaved equally viciously during the Battle of Galabrye (1078), which was a decisive conflict in the struggle for control of the empire. In it the nomads fought as allies of Nikephoros Bryennios. Their role was to attack the rear of the army commanded by Alexios Komnenos, who was then serving as Commander-in-chief (domestikos tōn scholōn) under Emperor Nikephoros Botaneiates. Initially, the nomads dutifully fulfilled this task, forcing some of the enemy units to flee. However, when they saw the enemy retreating in panic, they did not purse them, but instead, led by a lust for spoils, attacked Bryennios's rear guard, which created confusion in the ranks of the army, as warriors fled from them. ${ }^{544}$ This act of betrayal contributed to the defeat of the former duke of Dyrrachion. Another example is provided by Thietmar, who describes an episode during Bolesław I the Brave's first expedition to Kiev (1013) involving the rebellion of a Pecheneg auxiliary unit. Unfortunately, we do not know the reason for their mutiny, but this time, their turning against their ally was severely punished. The Polish ruler ordered the execution of the steppe-dwellers. ${ }^{545}$ Finally, during the last war between the Pechenegs and the Byzantine Empire, which took place in the years 1087-1091, the Pechenegs regularly violated agreements. ${ }^{546}$

Behaviour of this kind inevitably led to the construction of an image of the Pechenegs as extremely disloyal and unpredictable political partners. Such a perception of them, as we have seen, was dictated by actual experiences and not only by literary traditions. Another situation that contributed to the creation of the image of the Pechenegs as lacking a political shape was the lack of an overt decision-making centre. Their segmented political structure indeed made it difficult for neighbouring states to develop a means of communicating with them. In order for any political agreement to be binding for the whole community, it had to be accepted by all the tribes of the community, or at least the most important ones. These circumstances also made it more difficult for the nomads to hold to an agreement.

This multi-headed organism might have seemed to the elites of the neighbouring monarchies to be something akin to a horde of wild animals with which one could not make an arrangement, one which could not be controlled, and

543 Mich.Att., 476/7-478/9; Io.Zon., XVIII 18 (p. 717); Trapp 1986, 153. Cf. Chapter 7 of the present book.

544 Mich.Att., 528/9; Nic.Bryenn., IV 6-7, 9-13 (pp. 269-279); An.Kom., I 5-6 (pp. 20-27); Sewter 2009, 17-23. Cf. Chapter 7 of the present book.

545 Thietmar, vi 91 (p. 382).

546 Cf. Chapter 7 of the present book. 
which used and only understood the language of violence. It must be admitted, however, that the Pechenegs themselves contributed to this perception. At decisive moments they opted for instinctive solutions, which most often involved following native traditions and emphasizing their independence. Due to the absence of a strong decision-making centre, however, they did not understand the consequences of their choices, nor were they able to develop a far-reaching political strategy.

Their sense of community was based on an ethnic awareness that was experienced and manifested in various ways. Traditions were the main factor bonding the Pecheneg community. Unfortunately, little is known about these. Comparative material allows us merely to affirm the attachment of the people in question to a nomadic lifestyle and the activities associated with it. We know very little about the Pechenegs' native beliefs, although they were probably through institutions typical of steppe religions (e.g., the cult of ancestors) - one of the main determinants of their sense of community. The lack of data on a common origo gentis is troubling and puzzling. Apart from information about the 'Kangar' tribes, we do not know anything about the traditional version of the story of the origins of the Pechenegs. It is difficult to say whether this is due to gaps in our source base or to the true absence of such a story, stemming from the nature of their political organization, which shifted the cultivation of community traditions to the level of the individual tribe. The Pechenegs certainly cultivated their genealogy, though this also mostly occurred within the individual units of their political organization.

The strength of the ethnic solidarity among the Pechenegs is often questioned. ${ }^{547}$ Researchers emphasize in particular the alleged tendency of nomads to work in the service of foreign political powers (especially Byzantium) and the abundance of internal feuds that split their political organism. This kind of argument is not very convincing because such problems affected every community. Nothing here proves the particular susceptibility of the Pechenegs to the influence of various centrifugal tendencies. Even the betrayal of Kegenes, who could seemingly be considered an almost exemplary renegade, should be seen as an example of attachment to the community. The fact that he acted against it, or more specifically, against its leaders, should not obscure the fact that this community remained an important reference point for his actions to the very end. In fact, he consistently sought to gain power over the entire Pecheneg ethnos. His initial defeat in his rivalry with Tyrach resulted in Kegenes' finding himself outside the community. Together with his 
supporters, he became an outcast, a lone wolf. His entering into Byzantine service was not a break or a change in identity, but rather a means to continue carrying on his challenge. ${ }^{548} \mathrm{Of}$ course, there were cases of voluntary or forced abandonment of the native ethnos among the Pecheneg tribes. However, these were not always irreversible; moreover, they were often associated with cultivating the old (Pecheneg) identity in the new community. Although we do not know much about the components of the Pechenegs' ethnic traditions, it is worth remembering that for about 300 years these steppe-dwellers existed as an independent political organism, despite having experienced a number of severe crises that could have shattered their community. It would not have been possible to survive for such a long period of time without the existence and constant renewal of a strong sense of identity.

548 Cf. Chapters 6 and 7. 